
Digitized by the Internet Archive in 2007 with funding from Microsoft Corporation

http://www.archive.org/details/racialfactorsind00meanuoft 
Racial Factors in Democracy 
"Il faut bien connaître les préjugés de son siècle, afin de ne les choquer pas trop, ni trop les suivre."

Montesquieu

"The Europe of 1317 was a paradise compared to the Europe of 1917: and this is the result of six centuries of progress - progress which surely gives the Chinese, Indians, and other peoples to whom we are wont to consider ourselves so superior, every right to smile ironically - progress wbicb fills the soul of many a European with deep distrust. Is this progress? we may well ask . . . The Chinese and Indians may well ask if the European $W$ ar is to be regarded as another proof of that civilization wbich we are so anxious they should adopt. How many of us can be certain that the borrified world will not answer by rejecting as false that progress of which Europe was so proud?"

Guglielmo Ferrero 


\title{
Racial Factors in Democracy
}

\author{
BY \\ PHILIP AINSWORTH MEANS
}

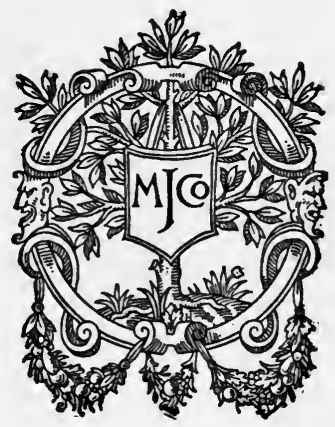

BOSTON

Harshall Fones Company

$\mathrm{M} \cdot \mathrm{D} \cdot \mathrm{CCCC} \cdot \mathrm{XVIII}$ 
COPYRIGHT'IOIO'BY MARSHALL JONES COMPANY

$$
\begin{aligned}
& \text { HT } \\
& 1523 \\
& M 4
\end{aligned}
$$

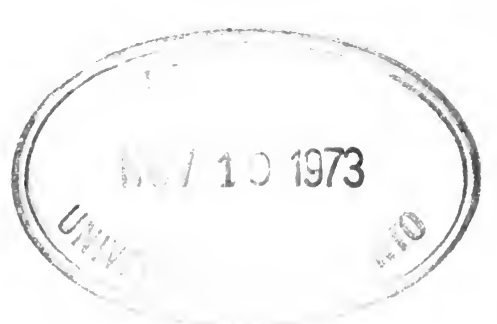

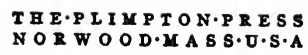




\section{FOREWORD}

$\sqsupseteq$ HOUGH the fundamental purposes of this book are benevolent and constructive, I

1 fear that some of my readers will find it difficult to believe so. If some of my remarks about our present-day civilization are found to be somewhat acrimonious, I beg the indignant critic to attribute their quality not to malice aforethought on my part, but rather to the very lively realization which I have of the fact that we are still far less civilized and enlightened than we are destined one day to be. Let all men and women who love the beauty and the goodness which the world contains, and who hate the ugliness and evil which, all too frequently, we see about us, strive, now and ever, to do their utmost to increase that which they love and to demolish that which they loathe. To encourage such a course of action is the chief motive underlying the pages which follow.

\section{Philip Ainsworth Means}

196 Beacon Street

Boston, MassachusetTs, U. S. A.

October 26,1918 


\section{ACKNOWLEDGMENTS}

I AM indebted to many persons for aid of one sort or another in the preparation of this book. Chief among them are Alleyne Ireland, Esq., who read the manuscript and made valuable criticisms, and Ralph Adams Cram, Esq., who did likewise. Edward T. Newell, Esq., kindly read the book in proof and suggested several valuable improvements. Messrs. William Churchill, Sylvanus Griswold Morley, Denman Waldo Ross, Oric Bates, Ernest A. Hooton, José de la Riva-Agüero, Manuel Gamio, and Aleś Hrdlićka are also among those to whom I, am indebted for much helpful advice. Professors Roland Burrage Dixon and Alfred Marston Tozzer of Harvard University, and Messrs. Isaiah Bowman and Marshall Saville of New York have, from time to time, given me aid and advice of a fundamental nature. Lastly, I am indebted to my mother, Mrs. James Means, for much help in the assembling of bibliographical material. 


\section{CONTENTS}

CHAPTER

PAGE

I. Introduction: A Discussion of Purpose and Method .................. 3

II. The Origin of the Human Race and the Inception of Human Culture........ 7 A. Lower Palcolitbic Times........... 7

B. Upper Palcolitbic Times............ II

C. The Transition to the Neolitbic Period. . 18

D. General Comments on the Palaolitbic Period....................... 18

E. The Neolithic Period Briefly Considered

III. A Study of a Series of Constantly Linked Cultures..................... 25

A. The Ancient Cultures of Anau, Turkestan...................... 25

B. The Civilizations of the. Tigris-Eupbrates $V$ alley and Related Regions........ 27

C. The Civilization of Egypt.......... 29

D. The Civilizations of Crete and of the Egean Region................ 37

$E$. The Cultures of the Mediterranean World, 1200-600 B.c................. 42

F. The Etruscan Civilization............ 46

G. The Aryan Civilization in India...... $5 \mathrm{I}$

H. The Early Periods of Far Eastern

Civilization................... 64 
I. The Civilization of Kbotan (Tarim Basin)................... 72

7. The Civilizations of Fava and Cambodia 77

IV. Partially Isolated and Completely Isolated Cultures................ 84 A. Partially Isolated Cultures.......... 84 B. The Isolated Cultures of America..... 87

V. The Fundamental Laws of Cultural Growth ..................... 126 A. The Nature of Culture............. $\quad$ I26

B. How Culture Grows............... $\quad$ I 28

C. The Essentials of Cultural Growth...... $\quad$ I35

VI. Democracy and World Civilization...... I4I A. Cultural Relationsbips and Racial Relationships................ I4I

B. The Nature of Democracy........... $\quad$ I53

C. The Need of Applying Democratic Principles to Cultural Relationships...... 165

VII. Democracy, Race-Appreciation, and Future Society................. I68 A. Majority Rule and Minority Rule..... 168 B. A Democratic Scheme of Government Founded on the Principles of RaceAppreciation................ $\quad 174$

C. Other Possibilities Latent in Race-Appreciation..................... $\quad \mathbf{1} 85$ 
VIII. The Anthropological Aspects of Coloni-

I. THE GENERAL HISTORY AND THE SIGNIFICANCE OF COLONIZATION....... I I 88

II. COLONIZATION FROM THE TIME OF THE ROMAN EMPIRE DOWN TO IgO0..... I94

III. THE GENERAL CHARACTER OF CERTAIN MODERN COLONIES.............. I98

A. Britisb India . . . . . . . . . I99

B. Britisb Egypt............ 200

C. French Algeria........... 201

D. Frencb Indo-Cbina......... 201

E. Japanese Korea (Chosen)

Fapanese Formosa....... 202

F. American Hawaii.......... 203

G. American Pbilippines........ 203

IV. THE ANTHROPOLOGICAL ASPECTS OF THE COLONIES NAMED............. 204

A. The Antbropological Aspects of British India........... 204

B. The Antbropological Aspects of

British Egypt........... 2I I

C. The Antbropological Aspects of

Frencb Algeria.......... 212

D. The Antbropological Aspects of

French Indo-Cbina. . . . . . 214

E. The Antbropological Aspects of

Zapanese Korea (Chosen).... 
$\mathbf{X}$

CHAPTER

F. The Antbropological Aspects of

American Hawaii......... 222

G. The Antbropological Aspects of

American Pbilippines........

224

v. OTHER ANTHROPOLOGICAL FACTORS IN COLONIZATION............. 226

ADDE NDUM

IX. General Conclusions

A. The Necessity of Having RaceAppreciation............... 232

B. The First Steps of Race-Appreciation in the Future............... 235

Bibliography.................... 249 
Racial Factors in Democracy 



\section{Racial Factors in}

\section{Democracy}

C H A P T E R I

\section{INTRODUCTION: A DISCUSSION OF PURPOSE AND METHOD}

D ECAUSE the whole world is now passing through the most critical period it has ever known, and because human culture and social civilization stand today in the doorway of a new period, it is well to examine introspectively the matter and nature of culture, that is, of man and of the manner in which he has placed himself in relations with natural and environmental circumstances.

As that period of European history which we call the Dark Ages marked the transition-from the cycle of civilizations which began in the East and culminated in imperial Rome to the new cycle of civilization which began with Charlemagne and is even now culminating in the great War, so our own time marks the beginning of a new transitional period. The old empires of the Eastern and of the Mediterranean world witnessed a struggle between 


\section{RACIAL FACTORS IN DEMOCRACY}

popular control (as expressed in clan and village councils) and autocratic control, and they saw the triumph of autocracy. The history of Europe in the period between about 750 and our own time has seen a strife between the people and their hereditary rulers, and it has witnessed the triumphant self-assertion of government by majorities. Neither autocracy nor rule by majorities has given the world perfect (or even almost perfect) government. The coming period of human development will see a struggle, perhaps short and sharp, perhaps long and indecisive, between rule by majorities and rule by minorities.

Parallel with the struggle to determine what sort of rulership there shall be, will exist a struggle to ascertain what sort of material and psychological (i.e., intellectual, moral and spiritual) culture shall prevail. In a word, both in government and in culture there will be an era in which the human race will be seeking to ascertain whether rulership is to be in the hands of the good minorities or in those of the evil majorities, and whether good cultural elements already existing in the world are to be gathered together, studied and generalized, or whether they are to be allowed to perish.

Likewise, in this era which is dawning, we shall be forced to amend our attitude toward other races. To quote Dr. Stanley Hall:

". . From prehistoric times man has been the great exterminator. Very long is the list of the animal species that he has swept off the face of the earth. Unique races of mankind, too, like the Beothuks and the Tasmanians, have been extermi- 
nated and left not even an Ossian to bemoan their fate. Every new advantage in the way of weapons or organization is prone to be turned against those next lower along these lines of development. . . . The time has now come, in our judgment, fully come when not merely philanthropy but science and even broadly based economy should teach us that primitives have certain inalienable rights to life, liberty, and the pursuit of happiness, and that ruthless interference with customs that have worked well for indigenous races should cease. . . ."1

The general aim of this book, then, is that of setting forth as briefly and convincingly as I can the exact nature of the principles which have governed the growth of civilization in the past and that of studying the application of those principles to current problems.

As this is an outline of principles rather than a critical history, I have chosen my examples of different sorts of cultures more for their illustrative qualities than for their actual historical importance. The matter of authorities and sources is one of no slight difficulty for him who is not a specialist in a given field. In none of the fields upon which I touch in these pages can I claim to be a specialist (save, perhaps, in the American field). Consequently I have many times found myself floundering helplessly in a sort of Sargasso Sea of controversy. In general, my policy has been that of using the newest and most compendious writings on any given subject, believing that works of that nature

${ }^{1}$ Hall, G. Stanley: The Point of View Toward Primitive Races. Jour. Race Development, 1910, I, pp. 5-12 (quotation from p. ๑). 


\section{RACIAL FACTORS IN DEMOCRACY}

will contain all the latest information and all the best critical explanations. This policy explains the omission from the footnotes of such names as Schliemann, Grote, Layard, Le Plongeon, Kingsborough, and Thomas.

My method has been simply that of giving a brief résumé of several distinctive human cultures in different parts of the world and in different periods of history. Using the material thus presented as a basis, I have shown just what are the fundamental laws that govern cultural progress, and then I have shown how we must more perfectly obey those laws after the war if our progress is to continue consistently and wholesomely. The age upon which we are now entering will differ from those which have gone before in that it will be an era of world-growth and world-civilization, not merely one of national growth and national civilizations. If we are to have democracy within the state, we must, to be consistent and true to our ideal, have democracy between states as well, likewise between races and between cultures. As each individual is to have the opportunity to develop the best qualities that are in him, so must races and cultures have the same opportunity. Only thus can a firm and united nation be created; only thus can a solid and permanent world civilization be built. 
C H A P T E R I I

\section{THE ORIGIN OF THE HUMAN RACE AND THE INCEPTION OF HUMAN CULTURE}

A. Lower Palaolitbic Times

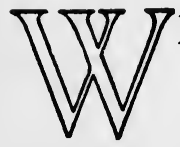

7 HEN Darwin first laid down the principles of the laws whereby man was evolved from the anthropoid apes, he established modern anthropological and ethnological science. ${ }^{1}$ For a long time the theories announced by Darwin and Wallace remained merely conjectures, though based on very sound logical grounds. It was not till the years 189I-94 that substantial proof of their correctness was forthcoming. At that time a Dutch army surgeon, Eugen Dubois, found in Java the remains of a being now known to science as the pithecantbropus erectus or ape-man of Java. ${ }^{2}$ The site where the remains were found is on the bank of the Solo or Bengawan River near Trinil in central Java. For general purposes the race represented by these remains is called the Trinil race or the Pithecanthropidæ.

1 Darwin, Charles: The Origin of Species. London, 1859; The Descent of Man. London, 2 vols., 1871. Wallace, Alfred Russel: Contributions to the Theory of Natural Selection. London, 1870; Darwinism. London, 1889.

2 Dubois, Eugen: Pithecantbropus erectus, eine Menschendebnlicbe Uebergangsform aus Fava. Batavia, 1894 . 
Without plunging into the discussion as to whether or no the Trinil race was in truth human, we will content ourselves with a brief account of those points which cause it at least to approach humanity. At the time when it flourished, some 475,000 years ago, Java was a part of the Asiatic mainland. Indeed, it now seems probable that southern Asia as a whole, rather than Java in particular, was the home of the Trinil race. The climatic environment may be described as cold-temperate. ${ }^{3}$ There were great forests through which roamed many animals, including the porcupine, hyæna, otter, rhinoceros, tapir, boar, deer, buffalo, wild cattle, and three sorts of elephants. The members of the Trinil race used to defend themselves from their fellow creatures and obtain their food by means of using natural or accidentally formed weapons such as fallen branches or conveniently shaped stones. The power of speech and that of forming ideas were both rudimentary; it is highly improbable that the use of fire was known.

The next chronological and morphological category of primitive man finds itself represented in western Europe, by a deposit of skeletal remains discovered at Heidelberg. The Heidelberg race was the earliest in that part of the great Eurasian land-mass, the date at which it existed being generally believed to be some 250,000 years ago. ${ }^{4}$ The environmental conditions were warm-temperate, and there was an extensive Africo-Asiatic fauna comprising elephants,

${ }^{3}$ Osborn, Henry Fairfield: Men of the Old Stone Age, pp. 76-84 and 511. New York, I9I 5.

4 Osborn, I915, pp. 95-II5. 
the rhinoceros, wild horse, wild boar, deer, moose, bison, aurochs, wolf, beaver, and other animals. Some cultural progression may be seen in the fact that flints were re-touched a little so as to shape them better to the hand of the user, but otherwise there was little change. In appearance the Heidelberg man was somewhat less ape-like than his Trinil ancestors, and there was considerable improvement in brain-capacity and intellectual power.

A third category is that variously called the Piltdown race, the pre-Chellean race or the Eoanthropus. Its habitat was western Europe, especially France and England. Definite advance is seen in the coups-de-poing (hand-stones) which were made at this period. Though crude, they nevertheless prove that the art of forming flint implements had already been evolved to a considerable degree. It is probable, also, that articulate speech had by now come into definite use. The Eoanthropus seems to have entered Europe by way of the south shore of the Mediterranean, the central date of its existence being fixed at some 125,000 years ago. ${ }^{5}$ At that time England, Ireland, and Iceland were all connected with the European land-mass. The Eoanthropus seems to have centered about the region where the English Channel now is, but traces of the race also appear in central Spain.

The next great race to make its appearance in

5 Osborn, 1915, pp. 126-144. Dawson, C.: On the Discovery of a Palaolithic Human Skull ... at Piltdown. Quart. Jour. Geol. Soc., LXIX, pp. I17-151. London, 1913. Prebistoric Man in Sussex. Zoölogist, ser. 4, XVII, pp. 33-36. London, 1913.

MacCurdy, George Grant: The Eolithic Problem. Amer. Anthrop. (N. S.), VII, pp. 425-479, 1905. 


\section{IO RACIAL FACTORS IN DEMOCRACY}

Europe is that which is called today the Neanderthal race. It extended over a tremendous stretch of time (roughly from 100,000 to 25,000 years ago). Nevertheless, it is possible to differentiate between the different periods and to describe the progress in culture made in each one.

The Chellean culture is distinguished by the beginnings of specialization as regards tools and weapons. Flints begin to fall into three wellmarked categories, i.e., scrapers, borers, and planing tools. ${ }^{6}$ The environment and the fauna remained much the same as they had been.

The Acheulian culture (about 75,000 to 50,000 years ago) was contemporary with a change in the climate. It grew less warm and considerably drier, the summers remaining comparatively warm but the winters being very cold. These conditions reacted upon man, causing him to seek for shelter in caves and to invent the art of making fire. ${ }^{7}$ Thus man was forced by nature to make the first great steps in building up his material culture, those of providing himself with a home and of heating it. The differentiation in tools became more marked, for utensils (coups-de-poing, scrapers, borers, and knives) became distinct from weapons (throwingstones, dart- and spear-heads). The more sensitive mammals disappeared from Europe at this time.

During Mousterian times (some 50,000 to 25,000 years ago) Europe had a cold, arid, tundra-like set of environmental conditions. The animals hunted by the Neanderthal race at this period were the

6 Osborn, 1915, pp. 148-165.

7 Osborn, I915, pp. 165-185. 
woolly mammoth, the woolly rhinoceros, the reindeer, the Arctic fox, the Arctic hare, and many others. The ibex, wild horse, wild cattle, and bison were also present. Man became a confirmed cavedweller. At the same time flint-working underwent considerable refinement. A new tool, the chopper or axe, was added to the list of those already in use. There is a great degree of elegance and symmetry in the flint implements made at this time.

Having passed through the three stages outlined, the Neanderthal race and its culture either died out or lost its identity. Osborn is of the former opinion and Hrdlićka of the latter. ${ }^{8}$ If Hrdlićka is correct in thinking that the Neanderthals merged with the next race to enter Europe, it is to be supposed that Neanderthal blood still flows in human veins today, albeit much diluted and mixed with other strains.

\section{B. Upper Palaolitbic Times}

As the Neanderthals were the race peculiarly identified with the latter part of the Lower Palæolithic, so is the Crô-Magnon race that which is especially associated with the Upper Palæolithic. The Crô-Magnons entered Europe about 25,000 B.c. Their evolution seems clearly to have taken place in Asia, and they reached their ultimate home by way of both the southern and the northern sides of the Mediterranean, entering Europe through Italy and Spain. Contemporary with their earliest

8 Osburn, 1915, pp. 202-257.

Hrdlićka, Ales: The Most Ancient Skeletal Remains of Man. Smithsonian Rept. for 1913, pp. 491-55़2. Washington, 1914. 


\section{I2 RACIAL FACTORS IN DEMOCRACY}

migrations was a negroid race known as the Grimaldi race. It was intrusive and not important. Neither the old Neanderthals nor the more recent CrôMagnons seem to have had any relations with it racially. ${ }^{9}$

Like the history of the Neanderthals, that of the Crô-Magnons is divided into three major periods, (each of which may be subdivided). The first of these is called the Aurignacian period. Its dates are roughly 25,000 B.c. to 20,000 B.c. At this time the cold, tundra-like conditions already mentioned still prevailed in western Europe, and man, as a result of them, continued to dwell in caves and caverns. This period witnessed the rise of art in Europe, and some of the pictures made at this time prove that huts made of logs and skins were also used, probably only in the summer time. ${ }^{10}$ The designs referred to here are called tectiform designs, and they probably represent man's earliest attempts to build himself a house. The tools of this period were made of stone and also of bone, the latter material being chiefly employed for needles and for harpoon-heads. Owing to the rise of art, several new stone implements make their appearance, notably gravers, scrapers with keel-shaped backs, etching tools, and chisels. Knives, drills, blades, and scrapers were the commonest industrial implements of stone, and the chief weapons were various sorts of shouldered points of stone designed for attachment to hafts. Bone javelin points were

9 Osborn, 1915, pp. 260-269.

${ }_{10}$ Osborn, 1915, p. 283.

Parkyn, Ernest A.: Prebistoric Art, pp. 75-83. London, 1915. 
also numerous. ${ }^{11}$ The older and less specialized coups-de-poing disappeared almost completely, being superseded by the newer and better utensils.

By means of this repertory of implements the Aurignacian Crô-Magnons produced a wide range of realistic representations. On the walls of their caves they painted pictures which display a wonderful sense of proportion and a keen appetite for beauty. The chief material was red ochre, and the favorite subjects were mammoths, woolly rhinoceroses, reindeer, horses, and ibexes. Theirs was an inborn creative genius the operation of which we may trace from its most humble and stumbling beginnings up to its splendid climax. The art of engraving was, in Aurignacian times, only embryonic. Sculpture, however, was already well developed at the end of the period, and one of its most remarkable products was a group of figurines, most of them representing female human beings. Limestone, soapstone, crystalline talc, and ivory were the favored materials. Extreme obesity seems to have been very common among the women of that time, often accompanied by that distention of the buttocks to which the name steatopygy is given. Though the features of the body are very realistically rendered, those of the face are scarcely even indicated. We also have incised or engraved representations of men and women dating from this time. The men were not fat. Spears and drinking-horns seem to have been used..$^{12}$

11 Osborn, 1915, pp. 306-308.

Parkyn, 1915, pp. 14-22.

${ }^{12}$ Osborn, 1915, pp. 316-330.

Parkyn, 1915, pp. 38-44. 


\section{RACIAL FACTORS IN DEMOCRACY}

At the end of Aurignacian times, Europe was invaded from the east by a new race, that of Brunn, which seems to have journeyed along the Danube valley. The period to which this invasion gave rise is called the Solutrean, and its dates are roughly 20,000 to 16,000 B.c. The newcomers seem to have plunged right into the midst of the Crô-Magnon race, causing a modification in their cultural development and likewise making them shift about considerably. There was but little art at this time, and what there was clearly partook of the nature of a survival from Aurignacian times. The greatest skill of the Solutrean invaders (or Brunn race) may be seen in their flint-working, which here finds its highest development. Never before had such symmetry and beauty of finish been achieved by Palæolithic flint-workers. The typical forms were the so-called "laurel-leaf" and "willow-leaf" spear heads most of them worked on only one side, and elongated flakes, notched at one end to enable them easily to be attached to a haft and worked on either one or both sides. Bone javelin-points, awls, and needles maintained a high level of excellence during this period. ${ }^{13}$

It now seems practically certain that the next period, that called the Magdalenian, was essentially a continuation of the Aurignacian and that both were peculiarly the product of the Crô-Magnon race. The dates assigned to Magdalenian culture are roughly 16,000 to 9,000 B.c. This long stretch of time falls into three parts, Early, Middle, and Late Magdalenian. Flint-working declined very

13 Osborn, 1915, pp. 33I-350.

Parkyn, 1915, pp. 120-126. 
rapidly, but it was compensated for by a general improvement in the working of bone and ivory. The climate gradually became less dry and tundralike and environmental conditions like those of modern Europe slowly asserted themselves. Great forests grew up all over western Europe.

From the Early to the Middle Magdalenian art there was a marked and perfectly logical transition, as, indeed, there was from Aurignacian art to Early Magdalenian. In the great caves of southern France and northern Spain we may see an imposing array of the later types of Crô-Magnon art. Similar, and doubtless related types are found in a far wider region, the horizon of the culture extending far eastward toward the Ural Mountains.

Engraving and painting may be described as the two most important means of artistic expression in Early and Middle Magdalenian times. Sculpture, including high and low relief as well as carving in the round, was also very general. We will describe briefly each one of these varieties of art, drawing chiefly upon the Middle Magdalenian period for our material. Most of the cave-pictures were made with what may be called a double technique, that is, the outlines and some of the details, such as eyes and hairs, were etched or engraved in the surface of the rock. That being done, color was applied, as many as four tints (yellow, red, brown, and black) being employed. Although the majority of these pictures were of single figures, a number of groups are also known, and in some of them, especially the French ones, there is a very well developed sense of perspective. The whole spirit and purpose 


\section{I6 RACIAL FACTORS IN DEMOCRACY}

of the art is realistic. The culmination of the mural decoration of the Magdalenian period may be seen on the walls of the cavern of Font-de-Gaume and on the ceiling of the cave of Altamira (in Spain). In addition to the wall-decorations there were numerous engravings on stone and bone, notably weapons decorated with bas-reliefs of animals. Ivory carvings representing delicately formed women with elaborately goffered headdresses make a sharp contrast with the gross obesity of the Aurignacian women. Nicely made stone lamps show us by what means the dark and tortuous caves were lighted. Altogether, it is easy to perceive that society, as well as devotion to the search after beauty, had made considerable headway by the end of the Middle Magdalenian era. It is highly probable that there was an orderly tribal organization, together with well marked occupational groups, such as priests or medicine-men, hunters, fishermen, and dressers of skins. Certainly man, at this time, had definitely achieved the possession of ideals, and something within himself already impelled him to seek to make all things fair to the eye. ${ }^{14}$ This general refinement is everywhere noticeable in the art of that period, and for that reason the utter absence, in Late Magdalenian art, of anthropomorphic and zoömorphic decoration is all the more surprising. ${ }^{15}$

14 Osborn, 1915, pp. $35^{1-449 .}$

Parkyn, 1915, pp. 44-126.

${ }^{25}$ Cartailhac, Emile, and Breuil, Henri: La caverne d'Altamira, Monaco, 1906.

Piette, Edouard: L'art pendant l'age du Rienne. Paris, 1907.

Déchelette, J.: Manuel d'archéologie prébistorique, celtique et galloromaine. Paris, 42 volumes, $1910-13$. 
From about 10,000 B.c. to about 7,000 B.c. there was a great relapse, but no true interruption, in culture. The Late Magdalenian and the so-called Azilian or Tardenoisian culture occupied this period. Not only were the changes in climate already mentioned as marking the transition from tundra conditions to the modern forestal conditions intensified, but also the old Crô-Magnon race was invaded by at least three wholly new stocks. One was a tall, light-haired, blue-eyed race which may safely be described as Nordic or Teutonic and which came in from the north, from the Baltic region. The second was a Mediterranean race which entered western Europe by way of North Africa and Spain. The third was an Alpine stock referred to by scientists under the name of Furfooz-Grenelle. It came into central Europe by way of the Danube valley, as the Brunn race had previously done, bringing with it a culture called Azilian or Tardenoisian of which a class of more or less oval pebbles with stylistic designs painted on them are the chief representatives. These pebbles or galets colorés are thought to have had a totemic or perhaps a mnemonic significance. ${ }^{16}$

The Azilian-Tardenoisian culture brings the Upper Palæolithic period to a close. The ethnical composition of the European population at that time may be understood from the adjoined Table.

16 Osborn, 1915, pp. 456-492.

Parkyn, 1915, pp. 92-117. 


\section{A TABLE SHOWING THE CHIEF PHYSICAL CHAR- ACTERISTICS OF THE PALÆOLITHIC RACES}

(Based on Osborn, 1915, pages 490 and 500)

\begin{tabular}{|c|c|c|c|c|}
\hline Race & Head-Form & Brain-Capacity & Coloration & Heigh \\
\hline $\begin{array}{l}\text { Trinil } \\
\text { Piltdown }\end{array}$ & $\begin{array}{l}\text { Long } \\
\text { Medium }\end{array}$ & $\begin{array}{l}850-1000 \mathrm{ccm} . \\
1300-1500(?) \mathrm{ccm} .\end{array}$ & & $5^{\prime} 7^{\prime \prime}$. \\
\hline $\begin{array}{l}\text { Neander- } \\
\text { thal }\end{array}$ & Medium-Round & $1250-162$ & & \\
\hline rô- & 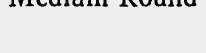 & $1250-1020$ cem. & & \\
\hline Magnon & Long & I $590 \mathrm{ccm}$. & & $6^{\prime} 0^{\prime \prime}$ \\
\hline Brunn & Long & $1350 \mathrm{ccm}$. & $\ldots$ & \\
\hline Alpine & Round & $1400 \mathrm{ccm}$ & $\begin{array}{l}\text { Hazel eyes } \\
\text { Chestnut hair }\end{array}$ & \\
\hline $\begin{array}{l}\text { Mediter- } \\
\text { ranean } \\
\text { Teutonic } \\
\text { (Nordic) }\end{array}$ & $\begin{array}{l}\text { Long } \\
\text { Long }\end{array}$ & $1500 \mathrm{ccm}$. & $\begin{array}{l}\text { Dark hair } \\
\text { and eyes } \\
\text { Very light hair. } \\
\text { Blue eyes. }\end{array}$ & . 1 \\
\hline
\end{tabular}

N.B. THE FIGURES GIVEN IN THIS TABLE ARE ONLY APPROXIMATE AVERAGES.

\section{The Transition to the Neolitbic Period}

The transition from Palæolithic culture, distinguished by the use of chipped stone implements, to Neolithic culture in which polished implements gradually superseded the older forms began about 7,000 B.C. The next age was marked by distinct advances in culture which will be noted presently.

\section{General Comments on the Palaolitbic Period}

From the point of view of the student of culture the period which we have just been discussing is chiefly important as being an era of zoölogical dis- 
persal. We have traced Palæolithic man from that part of the world in which he first evolved out of the higher forms of anthropoid ape into that of humanity in Europe. Palæolithic man, however, was by no means confined either to the chronological limits or to the territorial regions which have been considered, for he is found, both in vestige and in flesh, in many parts of the world. Even today we may say that in various parts of the world men are living whose habits of life are closely similar to those of the Palæolithic men of Europe. The Fuegians of South America are an excellent illustration of such a society. ${ }^{17}$ Another is seen in the Eskimo of Alaska, and still others in the Bushmen of South Africa, ${ }^{18}$ in the Tasmanians, Australians, Andaman Islanders, and others. For us it is sufficient if we conceive of the Palæolithic period as that part of the world's history in which the human race was distributed to various regions of the earth's surface in readiness for the reception of whatever cultural stimuli they might be destined to receive. If the circumstances, environmental and historical, of certain of these regions were such as to discourage or even prevent human progress after that distribution, we have ready-made a satisfactory explanation of the presentday existence of Palæolithic culture.

At this point it will be well to take up the matter of early man in America. In spite of the fact that various writers of varying degrees of scientific unim-

17 Cooper, John M.: Analytical and Critical Bibliograpby of the Tribes of Tierra del Fuego and Adjacent Territory. Bureau of American Ethnology, Bulletin 63, Washington, 1917.

18 Parkyn, 1915, pp. 126-131. 
portance or importance have claimed an impressive antiquity for man in America their pretensions now remain invalidated. Claims of this sort fall into two groups. One is that which sets forth the opinion that man not only has great age in America but that he originated there, passing through what is said to be a logical process or evolution. ${ }^{19}$ In the controversy over this matter Hrdlicka has heretofore routed and disproved all claims of geological antiquity for man in America. The other group of claims may be described as cabalistic, astrological, and pseudo-scientific. Its adherents are usually moved by a romantic desire to prove all sorts of fascinating and delightful cultural relationships for the American civilizations. In the nineteenth century many men, notably Ignatius Donnelly, Lord Kingsborough, Augustus le Plongeon, and John Delafield, strove hard but unsuccessfully to prove their beliefs to be true. Vainly were the Lost Tribes of the Jews, the Phœnicians, the Egyptians, and the Chinese appealed to for an explanation of the origin of American culture. An appalling mass of freak literature grew up around this theme, all of it distinguished by a complete lack of scien-

19 Ameghino, Florentino: L'bomme prébistorique dans le bassin de la Plata. Compte-rendu Con. inter. des sciences anthropologiques, pp. 341-350, Paris, 1878. La plus baute antiquité de l'bomme dans le NouveauMonde. Cong. inter. des Am. 2nd. Sess., pp. 198-250. Brussels, 1879. $L a$ antigüedad del bombre en la Plata. Paris, 2 volumes, 1880-81. Many other pamphlets by Ameghino treat of the same subjects. His chief followers are $\mathrm{H}$. von Ihering and R. Lehmann-Nitsche.

The claims of this school were nullified by: Hrdlićka, Aleś: and Willis, Bailey: Early Man in South America. Bureau of American Ethnology, Bulletin 52. Washington, 1912. 
tific method, by specious reasoning and pathetic gullibility. ${ }^{20}$

The truth of the matter is, probably, that some thousands of years ago (from about 5,000 to 10,000) a number of the Palæolithic cultured tribes of eastern Siberia began wandering over into Alaska and so gave rise to the American aboriginal population. Some of the Asiatic tribes referred to still exist, continuing in the same humble level of culture which marked them at the time when the settlers of America broke away from them. On arriving in the western continent some of the wanderers did

${ }^{20}$ The most prominent leaders of the romantical pseudo-scientific writers of this type are:

Smith, Grafton Elliot: Megalithic Monuments and their Builders. Man, XII, p. 173. London, 1912. The Origin of the Dolmen. Man, XIII, p. 193. London, 1913. On the Significance of the Distribution of the Practice of Mummification. Manchester (England), 1915. The Origin of the Pre-Columbian Civilization of America. Science (N.S.), XLIV, pp. 140-145, 1916. In these papers and many others, Prof. Smith does his utmost to prove an Egypto-Asiatic origin for American culture. He fails.

Posnansky, Arthur: Tibuanacu y las razas y monumentos prebistóricos. Inter. Cong. Am. 17th Sess., pp. 267-268. Buenos Aires, 1910. Una metropoli prebistórica en la América del Sud. Berlin, 1914. El gran templo del sol en los Andes. Bol. Soc. Geog. de La Paz, XVI, pp. 36-46. $\mathrm{La} \mathrm{Paz}, 1918$. These are some of the choicest papers of Sr. Posnansky in which he defends his opinion that the culture represented at Tiahuanaco in Bolivia dates from 13,650 B.c. to 4,600 B.c. His method is of the astrological variety.

Dick, Frederick J.: Notes on Peruvian Antiquities. Papers of the School of Antiquity, No. 3. Point Loma, California, 1915. This scholar is filled with a beautiful faith in the idea that various parts of Tiahuanaco were being built over a considerable period ranging from 850,000 B.c. to 10,000 B.c. He bases his opinion on the idea that that length of time is necessary to allow mankind to shrink from the size of the Easter Island statues to its present miserable proportions. There is much more literature of a similar nature. 


\section{RACIAL FACTORS IN DEMOCRACY}

not progress; others eventually reached regions where it was possible for them to do so. We may sum up this matter by saying that zoölogically American man is closely connected with Asiatic man, but that the cultural connection is slight and concerns the higher cultures of either continent not at all. ${ }^{21}$

We may regard Palæolithic Asia as a great wheel, at the hub of which man evolved from the anthropoidæ; as the wheel spun faster and faster little detachments of mankind were thrown out from its center by some sort of centrifugal force; some of them reached places and conditions favorable to development and progress; others did not, and so remained culturally stationary.

\section{E. The Neolitbic Period Briefly Considered}

The great contribution of the Neolithic period to human culture was the manufacture of pottery. The earliest types of pottery may be found in many parts of Europe, notably in the Swiss lake-dwelling sites, but true Neolithic pottery occurs very widely in western Europe, Crete, Scandinavia, Switzerland,

${ }^{21}$ Hrdlićka, Aleś: Restes dans l'Asie orientale de la race qui a peuplé l'Amérique. Cong. inter. d'anthrop. et d'archéol. préhist., 14th Sess., pp. 409-414. Geneva, 1912. Transpacific Migrations. Man, XVII, pp. 29-30. London, 1917. The Genesis of the American Indian. Inter. Cong. Am., I9th Sess., pp. 559-568. Washington, 1917.

Goldenweiser, A. A.: Diffusion vs. Independent Origin: a Rejoinder to Prof. G. Elliot Smith. Science (N.S.), XLIV, pp. 53 I-533.

Means, Philip Ainsworth: Some Objections to Mr. Elliot Smitb's Theory. Science (N.S.), XLIV, pp. 533-534. 1916.

Wissler, Clark: The American Indian, pp. 310-319, 342-366. New York, 1917. 
Bohemia, and England being especially rich in it. In quality, the pottery of this era ranges from the crudest attempts in a new technique to well-decorated and excellent vessels. It was all, of course, hand made. Incisions made with the finger nail or with a bit of wood were the first designs achieved. These increased in elaboration, and in time the use of color was understood. The art of stone-cutting progressed, also, dolmens, often elaborately (though somewhat incoherently) carved, being of frequent occurrence. Gold, in the form of beads, makes its first appearance, but it is very rare. ${ }^{22}$

Like the Palæolithic cultures, the Neolithic are not confined to any one region or to any one time. Some exist still; others vanished comparatively recently. In Europe, however, the Neolithic period seems to have flourished from about 7000 B.c. to about 2500 B.c. Domesticated animals, the practice of agriculture and the habit of a sedentary life began in this period, as they did in analogous periods all over the world. Wherever it occurs Neolithic culture is marked by the embryonic forms of cultural elements improved or perfected in succeeding stages (if such there be in each given area). ${ }^{23}$

22 Parkyn, 1915, pp. 133-162.

23 The literature which deals with this phase of culture is so enormous that I can do nothing better than merely refer to a few representatives of it, thus:

Pumpelly, Raphael Welles: Ancient Anau. Carnegie Institution of Washington. Washington, 2 vols, 1908.

Sykes, Sir Percy Molesworth: A History of Persia. London, 2 volumes, I9I 5 .

Rogers, Robert William: A History of Babylonia and Assyria. New York, 2 volumes, 1915. 


\section{RACIAL FACTORS IN DEMOCRACY}

Grenier, Albert: Bologne Villanovienne et Etrusque. Paris, 1912. Munro, Robert: Ancient Scottish Lake-Dwellings or Crannogs. Edinburgh, 1882. The Lake-Dwellings of Europe. London, 1890.

Czaplicka, M. A.: Aboriginal Siberia. Oxford, 1914.

Carruthers, Douglas: Unknown Mongolia. London, 2 volumes, 1913.

Munro, Neil Gordon: Prebistoric Japan. Yokohama, I9r. 


\section{A STUDY OF A SERIES OF CONSTANTLY LINKED CULTURES}

$\prod \begin{aligned} & \mathrm{N} \text { this part of my argument I shall try to trace } \\ & \text { out the historical and cultural connections be- } \\ & \text { tween a series of civilizations which were either }\end{aligned}$
directly linked to one another or were closely related
to one another through mutual ancestor-cultures.
The purpose here, of course, is to show the importance and action of cultural relationships.

\section{A. The Ancient Cultures of Anau, Turkestan}

This culture group forms a convenient one to start with for the reason that it seems to have been the parent of many civilizations. There are two kurgans or mounds at Anau which furnish us with a very detailed picture of the cultural history of the site. The North Kurgan is the older and presents the first and second of a group of four successive cultures. Culture I was clearly transitional from Palæolithic to Neolithic. There were no metal implements and no domestic animals. Flaked flints and other stone tools were used. Houses were built of air-dried bricks and were rectangular in form. Hand made pottery decorated with geometric designs painted on were in use. Although there were no domestic animals the wild horse, sheep, 


\section{RACIAL FACTORS IN DEMOCRACY}

gazelle, cattle, boar, and wolf were hunted for food, the weapons being wooden arrows hardened in the fire. There was a systematic cultivation of wheat and barley. The dates usually assigned to this culture are $9000-8000$ B.c. $^{1}$ In the upper portion of the North Kurgan are found the vestiges of Culture II. Considerable progress is here visible, for the use of lead and copper was beginning to be known, and there were, in time, several domesticated animals, including the pig, horse, goat, dog, camel, and cattle. Pottery remained much the same as it was in Culture I. The use of turquoise, lapis-lazuli, and carnelian became common. Although the houses were much the same as the earlier ones, the use of pivotal stones for doors to turn upon marks a step onward. The dates of this culture are about 8000 to 5200 B.c. $^{2}$ Culture III was represented by the lower levels of deposits in the South Kurgan. Houses were made of sundried bricks and painted pottery was made with the aid of the potter's wheel and furnace. Pivotal door-stones continued in use. Daggers, sickles, and lance-heads were made of copper alloyed with lead. Tin occurs sporadically. Terra cotta figurines of gods, goddesses, and cattle are frequently encountered. The dates are about 5100 to 2200 B.c., and in the latter part of the period there were clearly rather intimate relations with Elam, and with the Tigris-Euphratean kingdoms. ${ }^{3}$ After a

1 Pumpelly, I908, I, pp. 37-38.

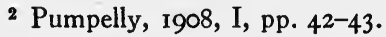

3 Pumpelly, 1908, I, pp. 43-44.

De Morgan, J.: L'bistoire d'Elam. Paris, 1902. 
gap of some seventeen centuries, Culture IV, a high iron culture, associated itself with the upper part of the South Kurgan.

The important thing about the Anau cultures from our point of view is that they show us exactly how culture may grow in a given locality. In the first culture life was a comparatively simple affair. But in Cultures II and III it became more and more complex, for none of the elements originated in the course of time were forgotten and the improved methods of making things were themselves constantly improved upon. There can be but little doubt that the region of Turkestan (in which Anau is situated) or perhaps it would be safer to say the westerly part of Central Asia, was the point from which several later civilizations derived their source.

\section{B. The Civilizations of the Tigris-Euphrates Valley and Related Regions}

The prehistoric period of the region in question includes the period from about 8000 B.c. to about 4000 в.c. It bears a close resemblance, and probably at least some degree of relationship, to the contemporary culture at Anau. From about 4000 B.c. to about 2900 B.c. the Tigris-Euphrates region witnessed a very great efflorescence of civilization. Cities were built, and life assumed considerable complexity. Sun-dried bricks of great size were used for buildings, but the skill of the architects of that day was not great. Most of the people lived in wattle huts daubed over with mud which was dried by the sun. Though pottery 
was known, alabaster vessels were more common. Sumer, Akkad or Agade, and Elam were the three great kingdoms at this time. Relations between them were of the closest description. The art of writing was in rudimentary form. The language of Susa, the capital of Elam, was Sumerian, with very strong influences from the related Semitespeaking people immediately to the North. In physical type these people were in contrast to the negroid aborigines whom they superseded. Susa and Lagash were the most important cities.

The historic period begins with the reign of Eannatum, King of Lagash, about 2900 B.c. He conquered Elam and established a true empire. The dynasty of Kish held the chief power from about 2750 to about 2650 B.C., and the great king Sargon I founded that of Akkad about the latter date. Sargon belonged to that romantic category of human beings composed of parvenu kings, of which David and Napoleon I are also members. He was found in the bulrushes while an infant, and, being loved by the goddess Ishtar, won for himself royal power. ${ }^{4}$

From the time of Sargon I down to that of Alexander the Great, and, indeed, into our own day, the history of the Tigris-Euphrates region has been like a great stream flowing uninterruptedly, though with varying current. From that region the tide of cultural impulse has ebbed and flowed many times in the course of more than forty centuries. But high civilization and a condition of more or less

4 Sykes, 1915, I, pp. 61-68.

Rogers, I9I 5, II, p. 25. 
emphasized imperialism have been characteristic ever since the days of Sargon I, whose empire included all of southwestern Asia and whose fleets rode the waves at least as far westward as Cyprus and probably much further. ${ }^{5}$

The religion of this early empire was of the same type as that which prevailed in later times in the same region. The pantheon was enormous, and it was divided into two general groups made of benevolent and malevolent deities. Three supreme gods stood above the others. These were Anu (the Heavens), Bel (the Earth) and Ea (the Abyss). For the worship of these personages and of the host of lesser ones a great aristocratic hierarchy of priests was built up. The king partook of a double character, sacerdotal and temporal. The religious observances were marked by austerity and by an aristocratic splendor of pomp and ritual, characteristics to which I shall have cause to refer later. The lesser gods were often partly anthropomorphic and partly zoömorphic. In no sense of the word was religion a popular affair; it was merely one of the means by which the populace was enthralled, enraptured and rendered obedient to its masters. ${ }^{6}$

\section{The Civilization of Egypt}

The long history of Egypt falls into a great number of chronological subdivisions, only the earliest ones being of interest to us in this connection.

- Winckler, Hugo: The History of Babylonia and Assyria, Translated and edited by James Alexander Craig, New York, 1907. pp. $30 \mathrm{ff}$.

- Sykes, 1915, I, pp. 64-70. 


\section{RACIAL FACTORS IN DEMOCRACY}

They may be tabulated, for the sake of convenience, in this way:

A TABLE OF THE EARLY PERIODS OF EGYPTIAN HISTORY

Dynasties

I, II, III

IV, V, VI

VII to $\mathrm{X}$

$\mathrm{XI}$ to XIII

$\mathrm{XIV}$ to XVII

XVIII-XX
Periods

Predynastic..........

(Calendar invented)..

Protodynastic........

Old Kingdom.........

Intermediate.........

Middle Kingdom.....

Hyksos..............

New Kingdom.......
Dates, B.c.

$4500-3400$

$\ldots . .4241$

$3400-2900$

$2900-2475$

2475-2160

$2160-1788$

$1788-1580$

$1580-1090$

N.B. THIS TABLE IS BASED UPON THE CHRONOLOGY OF JAMES HENRY BREASTED.

The people who lived in Egypt prior to Predynastic times had a culture oddly combining Palæolithic and Neolithic elements. Flaked instruments were used, but so were polished and hafted ones. The splendid flint-technique of these people lasted on into Predynastic times, and there were often finely chased handles of gold. The people of the prePredynastic times were presumably "Hemitic," that is, they were very likely Nilotic negroes who quickly yielded before the incursions of higher folk. ${ }^{7}$ At any rate, they have little to do with the semihistoric and historic peoples who concern us here.

Predynastic Egypt had a population of a threefold character, for it clearly contained three formerly

' Breasted, James Henry: A History of Egypt. New York, 1912. P. 25 ff.

I wish here to express my obligation to Mr. Oric Bates who, both in a course of African anthropology given by him and by Dr. E. A. Hooton at Harvard, and in private conversations, has given me much aid. Dr. Hooton, likewise, has made clear several points for me. 
separate elements. These were: (a) the "Hemitic" folk already referred to whose chief contribution to the later physical type of the Egyptians was that sub-nasal prognathism which may be seen in some of the ancient pictures; (b) The Libyans, who lived mostly in the northern or Delta part of Egypt; (c) The Semites, who probably came from Arabia and landed at about the latitude of Abydos, after which they dominated the region between there and Thebes. In time, the population of Egypt came to be a very thorough mixture of all of these. The language was strongly Semitic in structure, though having both Libyan and "Hemitic" elements in it.

In these early days Egypt-was all divided up into small states called "Nomes," each with its hereditary chief and local aristocracy. The material culture was far from being contemptible. Predynastic pottery, for example, falls into no less than eight classes, the polished black ware with a red finish, the polished red ware with cream-colored finish and a pink ware being the undecorated varieties; while another group was made up of black ware vessels with incised geometric designs sometimes filled in with white. Another class of predynastic pottery has considerable documentary value, for it consists of vessels with a light brown slip on which are painted in dark reddish brown designs comprising fairly elaborate ships with many oars, and stylistic patterns made up of ostriches, animals, and so on. This pottery was all hand made. Weaving had already been brought to a high stage of development, linen being the chief fabric for 
clothing. Stone, ivory, and bone ornaments were much employed, and they imply a considerable trade, as do also the Red Sea shells which were used. Though known and used, gold, silver, and lead were not yet important. Life was entirely sedentary and agricultural, lentils, beans, and barley being the chief food-crops, as flax was the principal economic crop, papyrus likewise being of importance. The domestic animals were goats, cattle, and the donkey. Even in those far-away times hunting for sport was a matter of great interest to the upper classes, the chief game being hippopotami, ibexes, ostriches, crocodiles, and wild boars. Fishing was also common, though it was probably confined to the lower orders. The houses of the period were made of wattle dabbed over with mud and then whitewashed or painted. They had windows as well as doors. Ownership marks on pottery and other things probably constituted the earliest form of writing. ${ }^{8}$

In Protodynastic and Old Kingdom days (34002475 B.c.) there was a gradual centralization of power and a steady rise in material culture throughout Egypt. The ancient noble families who had been the independent lords of "Nomes" slowly but surely became subservient to the overlordship of

8 Breasted, 1912, pp. 25-35.

Bates, Oric: The Eastern Libyans. London, 1914. Pp. $210-241$. Ancient Egyptian Fishing. Harv. Afr. Studies, I, 1917.

Randall-Maciver, David: El Amrab and Abydos. London, 1902.

Peet, E. T.: Abydos. London, 19I4.

Ayrton, E. R.; and Loat, W. L. S.: El Mabarna. London, I9I1.

Petrie, W. M. Flinders: Nagadab. London, I896. Pp. 6-42 and 47-67. Diospolis Parva. London, I90I. 
the King. This transition in governmental form is typified by the cemeteries of the period. Imposing and luxurious sepulchres or mastabas were erected by the heads of great families, but even the finest of them was overtopped and dwarfed by the still greater gorgeousness of the royal tombs. These last were the huge pyramids which, to most of us, are the sum-total of ancient Egyptian architecture. Official and court life assumed an air of great pomp and majesty. There was an elaborate and impressive etiquette, and an administrative hierarchy which was based, in part at least, on the old hereditary aristocracy composed of the nomarchs or nome-lords. The basis of society was the family. Woman's position was hardly any less respected than that of man, and children had to venerate both parents equally. Though the poor lived wretchedly enough, being tightly huddled together in closepacked ranges of small dwellings, the rich had large, airy and commodious residences with fine gardens all about them. Gay hangings shut out the sandstorms from the gallery-like apartments which were characteristic of the lightly built wood and adobe houses of that time. Beds, chairs, and chests were beautifully made of ebony and delicately inlaid ivory. Alabaster, gold, silver, and copper were used for vessels and various other objects.

In engineering skill the Egyptians of this period were well advanced, for the principle of the arch was understood and used as early as 2900 B.c. In art, which already played a rôle of great importance in their lives, there was a strong tendency toward realism, but even so early as this there is a noticeable 


\section{RACIAL FACTORS IN DEMOCRACY}

tendency toward dogmatic formalism and rigidity. Every phase of daily life was portrayed, for the xsthetic desires of the people were such as to make them wish to render all things beautiful by endowing them with gracious form and glowing colors. Yet their genius had a practical turn, rather than an idealistic one, and for that reason it was natural for them to draw upon their own daily occupations for artistic subject-matter. Thus we see their markets, and their well organized trade and shipping all presented in their stone and wooden sculptures and in their mural paintings. ${ }^{9}$

The first pyramid tombs were those of Snefru (Dynasty III, ca. 2940 B.c.). They are two in number, the smaller being at Medûm and the larger near Dashur. In his reign the royal power of Egypt was so strong as to be able to send a fleet of forty ships to the Phœnician coast to fetch cedar wood from Lebanon. The greatest of all the pyramids is that of Khufu (Cheops) (Dynasty IV, ca. 2900 B.c.) near Gizeh. It took 100,000 men twenty years to build it. The Sphinx was probably contemporary.

Egyptian culture was now in a very high state of development. There were no important cultural innovations in Egypt itself till the Hyksos period. The Hyksos or Shepherd Kings were mysterious

- Breasted, 1912, pp. 66-107.

Lythgoe, Albert M.; and Ransom, Caroline L.: The Tomb of Perneb, Metropolitan Museum of Art. New York, 1916.

Gosse, A. Bothwell: The Civilization of the Ancient Egyptians. New York, n.d.

Wilkinson, Sir J. Gardner: The Ancient Egyptians. London, 3 volumes, 1878 . 
invaders who came out of the North and established their rule in the land of Egypt. They were almost certainly Semitic, and their coming may be likened to that great immigration which first brought Semitic blood and language into the Nile valley. Their chief seat was at Avaris in the Delta, and for that reason very little is known about them, for their capital, like all Delta sites, has repeatedly been flooded by the River Nile and covered over with a thick coating of mud. Traces of the Hyksos have been reported from Crete, Bagdad, and Palestine, and it is probable that their commerce was very far-reaching, even though their actual power may not have been so. The Hyksos period fell between I 788 and I 580 B.c. To them Egypt of later days owed her horses and the art of chariotry. ${ }^{10}$ When the Hyksos were finally expelled from Egypt they retired into Palestine and Syria. It seems not improbable that this fact drew the attention of the Egyptians to that part of the world, for under Thutmose IV, Amenhotep III, and Amenhotep IV (ca. I420-I350 B.c.) the Egyptian power was carried into Palestine, Syria, and the Hittite lands. Egyptian influence made itself strongly felt, both by commerce and by royal alliances, in Crete, Cyprus, Mitanni, Babylonia, and Nineveh. Under the second of these kings, Egyptian power was carried as far south as the Fourth Cataract, and Nubia was deeply colored with the dye of Egyptian culture. Crete, Mycenæ, and the Ægean lands in general were profoundly influenced by Egyptian civiliza-

10 Breasted, 1912, pp. 215-222.

Wilkinson, $1878, \mathrm{I}$, pp. 15-18. 


\section{RACIAL FACTORS IN DEMOCRACY}

tion at this time, and the land of Yamen on the eastern side of the Red Sea was, for a while at least, under Egyptian domination. The Phœnician navigators and the conquering armies of the Pharaohs brought the Nile country into intimate relations with the non-Semitic Hittites and with the Mitannians. The latter were an offshoot of the Aryans, who were, as we shall notice later, undergoing a period of migrations and unrest, at this time. ${ }^{11}$ Egypt itself was at the pinnacle of her material and imperial grandeur. Life took on a complexity and luxury unknown even in the days of the pyramid-builders; Thebes and other cities displayed a riot of costly splendor which reminds one oddly of other periods of imperial intensity and dynastic success, such as the days of Elizabeth in England and of Louis XIV or of Napoleon I in France.

The religion of Egypt, in the period up to the time of the New Kingdom, resembled that of the Tigris-Euphrates region in that it was headed by a triad of chief deities. These were the children of Re, the Sun: Nut was the goddess of the Heavens; Keb was god of the Earth and Shu was god of the Air. Keb and Nut were the parents of Osiris, Isis, Set, and Nephthys. There was a throng of minor deities and a host of local gods, such as Amon, at first a local god, but later one of the most revered of all. As in the Tigris-Euphrates region, a priestly class grew up which won for itself the unquestioning allegiance of the masses by means of a never-ending series of ritualistic pageants, formal and colorful.

11 Breasted, I912, pp. 259-263, and 325-354.

Bury, G. Wyman: Arabia Infelix. London, 1915. P. 5. 
D. The Civilizations of Crete and of the Egean Region

As in the case of Egypt, it will be convenient if we tabulate the chronological sequence of cultures in the area now to be considered.

\section{A TABLE OF THE EARLY PERIODS OF CRETAN AND ÆGGEAN CIVILIZATION ${ }^{12}$}

Periods Dates, B.c. Contemporary Egyptian Period Neolithic....... Down to $2500 . .$. ... Sixth dynasty.

Early Minoan II..2500-2400........ Sixth and seventh dynasties.

Early Minoan III.2400-2200........Eighth, ninth and tenth dynas.

Middle Min. I...2200-2100......... Eleventh dynasty.

Middle Min. II.. .2100-1900. ........ . Twelfth dynasty.

Middle Min. III. . 1900-1700........ Thirteenth and fourteenth dynas.

Late Minoan I. . . 1700-1500......... Fifteenth to eighteenth dynas.

Late Minoan II. . I 1500-1450. . . . . . . Eighteenth dynasty.

Late Minoan III. . 1450-1200......... Nineteenth dynasty.

The Homeric Age. 1200-1 100.. . . . . . . Twentieth dynasty.

The Dark Age....1 100-700......... Twenty-first-twenty-fifth dyn.

The Hellenic Age $700-86 \ldots \ldots \ldots$ Twenty-sixth dynasty and Persian period.

The Roman Age. . 86 B.c. to 400 A.D. . . Roman period

In the Early Minoan I period Crete had, as Egypt had, the vestiges of a Neolithic culture which was definitely moribund, but which nevertheless exerted considerable influence on the Bronze Age culture which we call Early Minoan I. The people of Crete resembled the folk in Asia Minor in being Mediter-

12 This Table is compiled from the following sources:

Breasted, I9I2.

Hawes, Harriet Boyd: Gournia. Philadelphia, 1908.

Peake, Harold: A Brief Description of the History of the Civilization of the Old World. Newbury, England, rigr. 
ranean in race and non-Aryan in language. Even so early as this the mainlanders of Greece and the Balkan Peninsula were in sharp contrast with them, being either Alpines or Nordics in race and Aryan in speech.

The pottery of Early Minoan I and II was blackish. Sometimes it was burnished, and nearly all of it has incised designs, one of which, the Egyptian lilypetal pattern, indicates that already a contact of some sort existed between the Egyptian and Egean centers of culture. With this exception, the designs were mainly geometric. The pottery was hand made, the wheel only becoming known in Early Minoan III. In that period two new styles, a black ware finely decorated with designs painted in white, and a ware with a curious mottled black and red surface well polished. The shapes were odd but rather graceful. In the closely associated Cyclades Islands a lustre-finished ware, originating in Crete in the Early Minoan II period but never attaining great importance there, was very popular. ${ }^{13}$

Material culture in other respects during the Early Minoan times was modest, but by no means primitive. In the Cyclades the city of Phylakopi was already founded on the Island of Melos, and Crete, as well as mainland Greece and Hissarlik (Troy), had well-cultured settlements, notably Tiryns and Orchomenos (Greece) and Mochlos (Crete).

In the Middle Minoan period Cretan civilization reached its first climax. The cities of Knossos and Phæstos, as well as many less important ones, prospered. Trade with Africa, Asia, and Europe

1s Parkyn, 1915, pp. 207-212.

Hall, H. R.: Agean Arcbaology. Pp. 71-73. London, 1915. 
was very active. The influence of the Egyptian and Asiatic hieroglyphic systems was such as to change the picture-writing of Crete's previous period into a true system of script. To this period belong the various Snake-goddess figurines, one of the finest of which is in the Boston Museum of Fine Arts, from which we are able to get such an accurate idea of the female costume of the time. The women wore either tight-fitting flounced skirts or very full bulging ones. The jackets were tight, and cut in such a way as to expose the breasts. The men wore close-fitting short coats, and had exceedingly narrow waists. In costume these people seem to have departed widely from the Egyptians.

During the Late Minoan periods I and II, Cretan civilization reached its highest level. Gournia and Aghia Triadha flourished at this time, and the civilization which those cities show us was quite as high as that of contemporary Egypt. Well-built palaces, gay with frescoes and filled with beautiful furniture, faïence, splendidly made pottery, and metal objects, were the habitations of a complex and polished society. In trade Crete's influence reached the Greek mainland (where Mycenæ and Tiryns throve), Italy, Spain, Egypt, and Asia. During the Late Minoan I period the Dorians (Alpines or Nordics) invaded Crete and introduced there the art of chariot-building and horse-using. Nordic adventurers established at Hissarlik the socalled Sixth City, which is the Troy with which Homer deals. Egypt's influence was particularly marked in the matter of art, for the Cretans borrowed the realistic tendencies, which I have mentioned, 


\section{RACIAL FACTORS IN DEMOCRACY}

and improved upon them, building up a wonderful class of pottery decorated with octopus, dolphin, and other marine designs directly comparable in spirit and treatment to some of the life-form patterns to be seen on Egyptian pottery. In like manner, the ceilings of the Theban temples were copied on Crete, at Mycenæ and at Orchomenos. ${ }^{14}$

In Late Minoan II times a Dorian dynasty placed itself on the throne of Crete (I500-I 400 B.C.). To this period also belong the legends of the Minotaur and his labyrinth, the introduction of iron and the sports of bull-leaping and chariotry. The hunting of the wild boar with the aid of large fierce dogs was also a favorite pastime in this period. In these culture-elements, as well as in the form of the royal tombs and in the use of larnakes (pottery corpsecontainers) and of sarcophagi made of limestone splendidly painted with processions of men and women engaged in mortuary rites and with chariots drawn by griffins, one perceives a very thorough mixing of Mycenæan, Egyptian, Asiatic, and other influences, a mixing indicative of the complexity of Late Minoan civilization. ${ }^{15}$

In the Late Minoan III period the Dorians, Pelasgians, Achæans and other people from the mainland invaded Crete as they had been threatening to do ever since Middle Minoan times, and, indeed, since even earlier days. These people were Alpines

${ }^{14}$ Hall, H. R., 1915, pp. 19-22 and 71-144.

Breasted, 1912, pp. 337-339.

Hall, Edith H.: Early Painted Pottery from Gournia, Crete. Transactions, Dept. of Archæol. Free Mus. Sci. and Art. Pp. 191-205. Philadelphia, 1905 .

${ }^{15}$ Hall, H. R., 1915, pp. 172-177. 
and Nordics; their speech was Aryan and, though long ago they had been low-cultured, they were now thoroughly civilized. The strife between them and the Mediterranean, non-Aryan Cretans ushered in the Homeric Age in which war became an almost chronic condition. The struggles for supremacy between the Greeks and the Trojans has been perpetuated, in poetic form, in the Iliad and the Odyssey.

Following the Homeric Age was a so-called Dark Age in which the old non-Aryan culture and the old Mediterranean stock of Minoan times was slowly metamorphosed through the transfusion of new racial and cultural elements into that complex of culture and race to which we apply the term Hellenic.

In religion, as typified by folklore, the Minoans were far less dogmatic and pompous than the Egyptians and the Asiatics. If one may judge them by their art, the pantheon of Minoan times was full of those endearing qualities of freedom and grace which is so distinctive of the Greeks of classical times. A little of the rigidity which marks Egyptian art is, to be sure, present also in the mural decorations and the other branches of early Cretan art, but it is chiefly confined to those objects which clearly had a ceremonial character rather than a utilitarian one; indeed, the latter class of objects is marked by a very noticeable human character, for all the decorations which are not frankly stylistic are truly representative in spirit, and they have a very successful ambition to be completely realistic. A very similar differentiation may be seen, as I have already pointed out, in the art of Egypt. ${ }^{16}$

$$
16 \text { Hawes, 1908, pp. 7-9. }
$$




\section{RACIAL FACTORS IN DEMOCRACY}

By the year 776 B.c. (the date of the first Olympian games) the Aryan-speaking Hellenic population was compounded out of the diverse elements which went to make it up, and the classical Greek period or Hellenic period was definitely begun.

\section{E. The Cultures of the Mediterranean World, I 200-600 B.c.}

As $I$ indicated in the last section this was a period which witnessed the extinction of the old Minoan civilization of Crete and the ethnic preparation for the Hellenistic civilization. Though a period of profound racial and cultural disturbance, it was by no means a time of cultural eclipse. In several regions the old spirit was undiminished, though much modified. Egypt, of course, kept upon a very high level, though by no means so high as that which she had enjoyed. Relations were close with Assyria, and especially with the Hittites of Asia Minor, but the ethnic unrest in the North interrupted this during the Twelfth Century B.c. About II20 B.c., however, the Hittites drove out the Dorian invaders and reëstablished their power and their close relations with the Nile Kingdom. From that time onward, the Hittite kingdom was rich and powerful, its capital being Boghaz-Keui. Good roads, over which chariots and also four-wheeled wagons drawn by horses or by oxen traveled, knit all parts of the realm together and linked it with Syria and the South. Trade by sea was active, as it had been in Minoan days, for the Phœnician fleets plied everywhere throughout the Mediter- 
ranean world and even out into the Western Ocean. ${ }^{17}$ These enterprising people rendered humanity an inestimable service by acting as the carriers who bore the cultural message of Egypt to all the Western World. For fifteen centuries or more this had been the function of these civilizing Semites. Like their modern kinsmen, the Jews of today, it was often their lot to be almost without political individuality; their home was in every land, and their genius for trade took them into the remotest regions of the known world. By about II50 B.c. they were already a people venerable through age and welldeveloped culture, with several cities which hummed with busy trade. Of these Sidon, Tyre, and Arvad or Aradus were the most important. From about I600 to about I 200 B.c. the Phœnicians had been more or less completely under Egyptian suzerainty, but at the latter date the Dorian invasions caused profound changes in these arrangements, and the Phœnician cities were independent down to about 970 B.c., at which time Assyrian and Babylonian power began to make its influence felt. Under King Hiram (970-936) Tyre was in very close relations with the Israel of Kings Solomon and David. About 870 Assur-nazir-pal III conquered Sidon, Tyre, and Arvad, exacting tribute from them, and placing them under Assyrian rule. This state lasted till 605 B.c. when the Phœnicians became subjects of Chaldæa. In spite of their political vicissitudes and of their lack of autonomy,

17 Bates, Oric: The Eastern Libyans. Pp. 210-241. London, 1914. Garstang, John: The Land of the Hittites. Pp. 52-55, 199, 363-365. London, 1910. 


\section{RACIAL FACTORS IN DEMOCRACY}

the folk of Sidon, Tyre, and the other cities were unflagging in their commercial and culture-spreading activities. In the Ninth Century B.c. they founded colonies, not only Carthage and Aoza, but also Heraclea (on Sicily), Melita (Malta), as well as many others, notably those on the islands of Sardinia and Corsica and those in the Tartessus region (southwestern Spain). Even as early as the Twelfth Century B.c. they had had important depôts at Cadiz and Lixus (Mauretania). They even went so far north as the Scilly Isles in their search for tin and other metals. In the course of years Carthage gradually became the chief Phœnician city.

The material in which this wonderful maritime nation traded was diverse in its nature. Textile fabrics, some of them dyed with the famous Tyrian purple, objects of silver, gold, iron, copper, and bronze, glass from Egypt, and the knowledge of the alphabet and of arithmetic were a few of the elements of culture which they spread broadcast. Having no artistic genius peculiar to themselves, yet being skillful copyists and clever imitators, the Phœnicians colored their æsthetic tastes with Egyptian, Asiatic, Cretan, and Mycenæan art, and bore motives very separate as to their origins into many lands where later artistic traditions were built upon the basis provided by the Phœnician traders. The Mediterranean world at this period may, therefore, be conceived of as the seat of hoary civilizations which were being invaded from the North by the fresh Alpine and Nordic blood of southeastern Europe. Yet through all the resultant confusion the Phœnicians act as the cord which 
binds the old cultures with the newer ones, which links ancient Egypt and Asia to young Greece, Carthage, and Etruria. ${ }^{18}$ Not unnaturally, Phœnician religion resembled those of Asia and of Egypt. It was, if anything, more repellent even than they, and in addition to the human sacrifices made for the god Milk or Moloch, there were disgusting orgies for the delectation of Astarte.

Carthage, which flourished from about 8 I3 3 B.c. to about 202 B.C., derived the blood of its ruling class, the greater part of its material culture, its religion and its language from Phœnicia. The once proud and independent Libyans were but mercenaries in its armies; the Nomad tribes were irregular allies; slaves from the Soudan were numerous. Trade was very active. Grain, ivory, and skins came from Libya, copper from Cyprus, iron from Elba, tin from Cornwall, gold and precious stones from Malabar. The grand and imposing architecture of Phœnicia, characterized by massive walls built of huge stones, was mellowed by all that was delicate and graceful in Greek architecture, but the native skill and ability of the Phœnicians continued to display itself in such matters as navigation, hydraulics and irrigation, and agriculture. Carthage, through her far-flung colonial empire, exercised a tremendous cultural influence. ${ }^{19}$

Rome, before attaining her destiny, must needs vanquish this Semitic culture, though not scorning to borrow many of its characteristics.

18. Cooke, George Albert: Pbonicia. Article in the Encyclopædia Britannica, I Ith ed.

19 Graham, Alexander: Roman Africa. London, 1902. 


\section{F. The Etruscan Civilization}

As in the case of Anau, and in those of Egypt and Crete, the civilization we are about to consider was deeply rooted in a past of respect-worthy complexity. For this reason it will be well for us again to tabulate the chronology involved.

\section{A TABLE OF THE CULTURES OF ITALY, ESPECIALLY THOSE OF ETRURIA 20}

Name of Culture Remarks

Approximate Dates, B.c.

Neolithic. Down to 2200

Bronze I .......An orderly progression in culture on Bronze II the part of Alpine Lake-dwellers from Bronze III Switzerland. A Nordic aristocracy appears to have been present. The people led water from the rivers to moats around their towns. Considerable trade with the Agean.........2200 to 1300

Bronze IV...... Tyrrhenians (Alpines with Nordic chiefs) arrived in Po valley from the East by way of the Adriatic. Agriculture, cattle and pigs were known. Toward end of period iron was brought in from Central Europe........... 3300 to 900

Iron I........ The new Iron culture was introduced Iron II from the North by people who set up (Or Villanova) the Villanova culture, driving older tribes south into Latium where they founded Rome. Active trade with the East through Phøenicians and Greek colonies in Sicily ............... 900 to 700

Etruscan................................. 700 to 500 Gallo-Roman............................ 500 to 300

${ }_{20}$ This Table is compiled from material derived from Peake, 19r4, from notes made by me while taking a course under Dr. E. A. Hooton, at Harvard University in 1915 , and from

Norton, Richard: Etruria (History) Encyc. Brit., IIth ed. 
The Bronze Age periods above referred to may be considered as being more or less closely related with the Bronze Age cultures in France, England, and Scandinavia, cultures with excellent but for us unimportant, development. In all of these countries, as well as in Spain and in the Balearic Islands, there were Bronze Age cultures which had many elements and characteristics common to all, and which were, in time, merged with Iron Age cultures which eventually yielded to the eagles of Rome. Everywhere, but especially in Spain, Italy, and the Balearic Islands, there is a clearly perceptible strife between the tall, dolichocephalic blond Nordics and the Mediterraneans. Often the Alpines are associated with the Nordics in a more or less subservient capacity. In some regions, particularly England and Ireland, the name Celt or Kelt is given to these Nordic folk and to the remarkable culture which they had. ${ }^{21}$ In France they were known as Gauls and in Spain as Celts or Celt-Iberians.

It is necessary to bear all the foregoing in mind if one is to appreciate the significance of the Etruscan civilization from our point of view here. The Etruscans had a civilization which was of the first

${ }^{21}$ Peake, 1914.

Parkyn, 1915, pp. 163-206.

Montelius, Oscar: Kulturgescbicbte Scbwedens von den ältesten Zeiten. Leipzig, 1906.

Cartailhac, Emile de: Monuments primitifs des Baléares. Toulouse, 1892.

Paris, Pierre: Archéologie en Espagne. Paris, 2 volumes, 1903.

Ramis y Ramis, Juan: Antigüedades célticas de la isla de Menorca. Mahon, 1818. Historia de Menorca, 1819.

Markham, Sir Clements R.: Majorca and Minorca. London, 1908.

Armstrong, John: History of Menorca. London, $175^{2}$. 


\section{RACIAL FACTORS IN DEMOCRACY}

order, but, unlike those of Crete and of Egypt, its antecedents were by no means humble. Etruscan civilization may be likened unto a flowery capital that surmounts a tall shaft of fine marble.

The classical explanation for the origin of the Etruscans is that they came from Lydia in Asia Minor and settled in Italy. As a matter of fact it now seems clear that the Etruscan population was made up of ethnic elements derived from both East and North. At this point it will be well to point out that Etruscan civilization occupied a much larger territory than that now called "Etruria." The power of the ancient Etruscans included Latium, Etruria, Umbria, and a large part of the Po valley. There was a famous League of the Twelve Cities (which included Veii, Tarquinii, Clusium, Cære, Cortona, Volaterræ, Vulci, Volsinii, Perusium, Voltumna, and others). In each of these we may see a complete State, each city being sovereign not only over smaller towns in its vicinity, but also over flourishing colonies sent northwards into the Po valley. Power was lodged entirely with an aristocracy which chose from its own number a chief who had the title of lucumon. This is a condition somewhat like that which prevailed in Predynastic Egypt. In Etruria, as in the East, the commonality was quite voiceless as far as the government was concerned; there were no provisions even for ascertaining their desires. In religious matters, as in governmental, Etruria resembled Egypt. The dominating characteristic of her worship was a combination of pompous austerity with gloomy grandeur, and utter artificiality. Unlike the cheerful, graceful, 
and rather informal mythology of Greece, the creed of Etruria was a deliberate fabrication of the ruling class, which, combining as it did the functions of a priesthood with those of a temporal aristocracy, not unnaturally sought to attain its ends by the exercise of a fear-inspiring spiritual domination. To this end the lucumones, like their prototypes in Egypt and Asia, provided many elaborate ceremonies which partook of the nature of pageants and spectacles. The very large pantheon was headed by the triad made up of Tina, Thalna, and Menrvra (Jupiter, Juno, and Minerva). There was supposed to be an endless combat between the benignant and the malignant powers of the pantheon, in which, as in so much else, one sees a simulacrum of eastern conditions.

In artistic matters the Etruscans closely approximated their tutors who might be now the Phœnicians, now the Greeks. Like the former, they were skillful imitators but not originators. This characteristic, combined with the very active trade carried on by the Phœnicians and by the Etruscans themselves, explains why numerous Egyptian artifacts have been found in the Etruscan tombs of the earlier times and why Greek influence became dominant in art later on. A few examples of this class of objects may fittingly be mentioned. Such are the ostrich eggs, with painted or engraved decorations; these obviously are of Egyptian provenance. Similar in this respect are the enameled vessels sometimes found. The famous black ware (bucchero) of Etruria of ten shows a mixture of Greek forms and Egyptian or Asiatic designs. In archi- 
tecture, especially in the matter of sepulchral architecture, the Etruscans remind one strongly of both the Mycenæans and of the Egyptians. The houses and the way of life of the Etruscans were exceedingly well advanced, a good degree of comfort and luxury being maintained by a society based on a well-organized agricultural basis.

During the great days of Etruria's power Rome was but a minor town. For a time she was ruled by a dynasty of Etruscan kings. After these were driven out, the little city had to defend itself against all the powers of Etruria. The result of this domination, temporary though it was, was to carry the stream of civilization which we have been following so long into Roman times. ${ }^{22}$ The Romans not only borrowed their ritual, their games and shows, their augury, their weights and measures, their calendar, their architecture, and their agriculture from the Etruscans, but they were themselves distinct from their teachers only because of their political independence. Rome, in borrowing her whole civilization from Etruria, made the first step in a series of similar adoptions, the next being concerned with the Greeks and later ones with Egypt, Western Asia, and India, successively.

${ }^{22}$ Dennis, George: Cities and Cemeteries of Etruria. London, 2 volumes, 1878 .

Vergers, Noel des: L'Etrurie et les Étrusques. Paris, 3 volumes, 1862-64.

Grenier, Albert: Bologne, Villanovienne et Étrusque. Paris, I912.

Seymour, Frederick: $U_{p}$ Hill and Down Dale in Ancient Etruria. London, 1910.

Rawlinson, George: The Origin of Nations. New York, 1903. 


\section{CONSTANTLY LINKED CULTURES $5 \mathrm{I}$}

\section{G. The Aryan Civilization in India}

While following so closely the course taken by civilization on its way into Europe, we have rather completely lost sight of the Eastern world. Inasmuch as Bishop Berkeley's saying that "Westward the course of empire takes its way" is no longer looked upon as wholly true, let us now examine the means by which civilization was spread over the Asiatic continent.

In early days a large part of India was held by people who were of the negroid type. Their culture was excessively low, being about equal to that of the native tribes of Australia. This stratum of population seems to have been invaded by an offshoot of the Mediterranean race and by some Alpines, the former coming from the Northeast, the latter from Tibet. These two invading stocks mixed with the aborigines and became much more dark in skin-color than they had been. They spoke languages related with the Tamil and the Telugu of today, and the composite population gradually formed several groups, the chief of which was that called Dravidian. The cultural status of most of India at this period was very low, though copper and a crude sort of pottery were known. Some of the Dravidians, by about I 500 B.C., had built up a fairly respect-worthy civilization, though their religion was marred by being extremely obscene. At about the date I mention there was the first of a long series of invasions by the Aryan-speaking Nordic tribes who dwelt in the Northwest. This movement by the Aryans may be likened to the 
more or less contemporary southward drift of very similar people in central Europe down into the Mediterranean world with its long-established civilizations. Though probably not directly related, the two movements may be looked upon as being indicative of profound ethnic unrest in the lands to the North of the Balkans, the Black Sea, the Caucasus, and the Hindu Kush, an unrest which caused the Nordic, Aryan-speaking tribes who dwelt in that huge and ill-defined region to seek new homes for themselves in the southlands.

It will clarify matters if once again we tabulate the chronology.

\section{TABLE OF THE CULTURE-PERIODS OF INDIAN HISTORY 23}

Periods

Remarks

Approximate

Dates. B.c.

Prehistoric. (See

above)................................. Down to 1500

Aryan invasions........................ 1500 to 1000

Vedic period........................... 1000 to 600

Saisunaga

Dynasty............................60 to 321

Gautama Buddha. . 563-483

${ }^{23}$ This Table, which takes no account of the various minor cultures and kingdoms of India, is based upon material gained from:

Peake, 1914.

Barnett, Lionel D.: Antiquities of India. London, 1914.

Smith, Vincent A.: Asoka. Oxford, 190r. The Early History of India. Oxford, 1908. The Oxford Student's History of India. Oxford, 1916.

Hopkins, E. Washburn: India Old and New. New York, 1901.

Dutt, Romesh Chunder: History of India from the Earliest Times down to the Sixtb Century B.c. London, 1906. 
Maurya Dynasty........................ 321 to 232

Alexander the Great's Invasion..327-

324. Chandragupta's wars with the

Seleucidæ. . 308-297

Reign of Asoka. .272-232

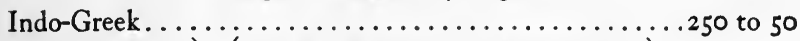

Yue-Chih

$\left.\begin{array}{l}\text { Kushans } \\ \text { Kwei-Schwang }\end{array}\right\}$

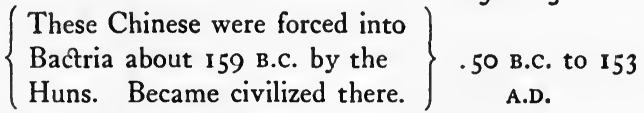

King Kozulokadphises (Kien-tsien-

k'io) united all the Kushans under him

and conquered Kabul valley and

added it to his kingdom which reached as far as the Caspian Sea. Reigned about 45-85 A.D. King Kanishka reigned over all Northern India and conquered Kashgar and Khotan. I23153 A.D.

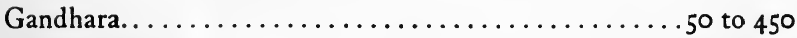

Gupta Empire. 320 to 450

Invasions of the

White Huns............................ 450

During the period of the Aryan invasions and the so-called Vedic period, both material culture and social factors were in a state of flux and modification. Thanks to the Vedic poems we are able to form a fairly accurate conception of the state of culture and society in those distant days. The Vedas are several in number, the three which concern us being: The Rig-veda proper, a complicated group of poetical and philosophical compositions immensely divergent in point of age, but probably in their present form by 600 B.c., if not by 1000 B.C.; the Atharva-veda, dating from about 600 B.c.; and the Upanishads, dating from the seventh century B.c. Although these dates may seem comparatively modern, it should be remembered that 


\section{RACIAL FACTORS IN DEMOCRACY}

the conditions portrayed in Vedic literature existed during many centuries previously. Then, too, there is a vast amount of material to be had in the Mahabharata, an epic poem seven times as long as the Iliad and the Odyssey put together. It depicts the strife between the racial groups in India during those early days, dating, like the Vedas, from about 600 B.c., as far as its present form is concerned, that is. ${ }^{24}$ Society at this time was based on agriculture aided by irrigation. The domestic animals were cattle and horses, both being used for draught animals, the knowledge of how to build chariots and carts having been brought in by the Aryans from Central Asia. Copper, bronze, and iron were known, though probably the last was of considerably later introduction than the two other metals. Houses were made of wattle-and$\mathrm{dab}$ as they were in so many ancient societies. Textiles were very finely made, and writing appears to have been known from very early times. The country was divided up among numerous kings, each of whom ruled over a strongly centralized state with several cities. Of these some of the more important were Indra-prastha (Delhi); Mathura, Kausambi, and Kanyakubja (respectively Muttra, Kosam, and Kanauj) three cities forming the confederated kingdom of the Panchalas; the kingdom of Kosala (Oudh), with Ayodhya as its capital; and the aristocratic republic of Vaisali. In a word, the whole Jumna-Ganges drainage may

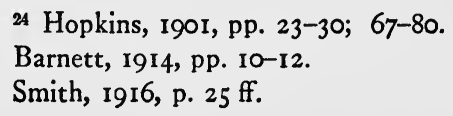


be regarded as the seat of the Vedic society under consideration. Just south of the Tropic of Cancer is the Vinhya mountain-range which, running almost directly east and west, forms the dividing line between Aryan and Dravidian India. ${ }^{25}$ The numerous kings, of greater or lesser importance, lived in timber palaces surrounded by wooden palisades. At first the king seems to have been elected by some sort of assembly of freemen, but during the Vedic period his power became hereditary and absolute, while at the same time his person became semi-sacrosanct. A goodly degree of pomp and luxury hedged the sovereign about, but nevertheless his life was far from being an idle one, for he had definite tasks and duties, among them being that of acting as the leader in war. For administrative purposes the king was aided by an elaborate bureaucracy, and society was well organized and governed. There were two sorts of social categories, vertical and horizontal. The former sort is typified by the clans and families which made up the many village communities in which the bulk of the population dwelt; the latter is represented by the castes which were uniform from village-group to village-group, a fact which constitutes the horizontality. The clans were exogamous, but the castes were strictly endogamous. In Vedic times there were but four chief castes: the Brahmans, the Kshattriyas (warriors), the Vaisyas (husbandmen), and the Sudras (slaves). The villages in many matters acted, through their headmen and other officials, as a unit, and they

25 Barnett, I9I4, pp. 12-14. 
were combined into groups of ten, the ten headmen being responsible to an official who had charge over ten villages. $\mathrm{He}$, in turn, was answerable to a still higher officer who controlled one hundred villages and he to one who ruled one thousand. A very close parallel to this admirable system existed in ancient Peru, as we shall have cause to notice later on. Within the village there were patriarchal families, each being ruled absolutely by the head of the family and his almost equally revered chief wife. ${ }^{26}$ In actual practice the endogamy of the caste was frequently ignored so as to permit a woman to "marry upwards," but a man who "married downwards" was not approved of. From these infringements originated the newer castes (which now number about 2400). Monogamy was the general rule, but there was much concubinage and some polygamy. In the Vedic period, then, one sees the foundations of future North Indian society. South India does not here roncern us, save that we should remember that the Dravidian type of civilization there maintained its own kingdoms, borrowing much from the Aryan northland.

Vedic religion began by being a wholesome, clean, and virile Nature-worship, but when the Aryans established themselves in India they became engrossed by such external questions as ritual and theology and corrupted by the gross influence of the Dravidians. By the Sixth Century B.c. an enormous pantheon, a rigid sacerdotal hierarchy and a mass of dogma had grown up, together with ${ }^{26}$ Barnett, 1914, pp. 105-114. 
all sorts of moral, fiscal and political abuses. Against these degeneracies the life of Gautama Buddha constitutes a vigorous reaction. He was opposed to the caste-system, for, like Jesus Christ, he was a democrat and was opposed to all the social injustices which he saw about him. He denied the continuity and transmigration of the soul and its final haven in Brahma (the Supreme Being). For the repellently dogmatic and heartless ritualism of the established religion he proposed to substitute a noble, democratic state of fraternity to be characterized by temperance, chastity, and moderation in all things. His was a nature so majestic and so filled with lofty ideals that it has seldom been equaled, save by Jesus Christ, and never surpassed. Like Christianity, Buddhism has a doctrine of salvation. The death of a human being is regarded by that faith merely as the doorway through which the life-stream passes into a new being, and the re-born life partakes of the exact nature that its behavior in the former life deserves. The processes of death and reincarnation repeat themselves many times until good and evil have been rewarded and punished according to their deserts. Thereafter there is release for the soul which seeks its everlasting rest in Nirvana, a state of freedom from the "wheel of life." Pure Buddhism has a loftiness and a spiritual sweetness quite the equal of those found in pure Christianity (that is, primitive Christianity), but, like the latter religion, it seems that Buddhism has been fated to collide, in various periods and regions, with other faiths and other temperaments which have reacted upon it harmingly. The Lama- 


\section{RACIAL FACTORS IN DEMOCRACY}

ism of Tibet and the Buddhism of Ceylon may be looked upon as examples' of these corruptions.

The days of the Saisunaga dynasty were hardly more than a continuation of the Vedic period. Save for the conquest of the Indus valley by Darius of Persia about 5I2 B.c., and save also the life of Gautama Buddha, nothing of any particular cultural importance took place until 327 B.c. when the Indian campaign of Alexander the Great, King of Macedon, began. The significance of that event chiefly lies in the fact that it was the first thing to bring India into direct contact with the Mediterranean world. Alexander continued in northwestern India till 325 B.c., receiving the homage of many native kings and princes. In October of that year he retired to the westward, and two years later he died. Although there is a strange reticence regarding the conquests of Alexander on the part of Indian writers, it seems almost inevitable that many Persian and Grecian elements should have made their appearance in India at this time.

On Alexander's death his vast empire broke up into several kingdoms, themselves of considerable extent. Such were the Ptolemaic kingdom in Egypt and the Seleucid kingdom in Bactria, Persia, Syria, and Asia Minor. ${ }^{27}$ The contact between the

${ }^{27}$ The names and dates of the Seleucid kings who have bearing on India are as follows:

Seleucus Nicator, 312-280. Makes a treaty with Chandragupta.

Antiochus I (Soter), 280-262. Conquered invaders from Central Europe. Antiochus II (Theos), 262-246. Wars with Egypt and Parthia.

Antiochus III (Great), 223-187. Greatly enlarged his realms. Was in India 209-204.

Antiochus IV, 175-164. A great Hellenist. 
Seleucid realms and India was culturally very stimulating, though almost consistently hostile.

Chandragupta Maurya (reigned 32I-296) founded the great Maurya dynasty with which the real history of India may be said to begin. In his day civilization in Aryan India reached a high level. His capital was Pataliputra (Patna) on the Ganges. All around it ran a massive wall built of finely prepared timber and provided with a plenty of gates and towers. Though the palace, like the wall, was built mainly of wood, it was very magnificent, being carved and painted with great skill and thus endowed with suitable splendor. Fine hangings and luxurious fittings of all sorts gave a background of comfort and magnificence to a court life which was very elaborate. The king had an immense crowd of persons in constant attendance upon him, including a bodyguard of women, chamberlains, ministers, and an assortment of concubines, dwarfs, and hunchbacks.

The armies of Chandragupta seem remarkable in size even today; they must have been formidable indeed during his own lifetime. The military establishment of Chandragupta was organized in this manner: there were 9,000 elephants with 36,000 men to attend to and use them; there were 8,000 chariots, requiring $24,000 \mathrm{men}$; there was a well-organized commisariat and a large naval force; and finally there were about 600,000 ordinary infantry. ${ }^{28}$ Nor was the civil administration a bit less admirable, for it followed the lines already described and was splendidly kept up.

28 Smith, V. A., I908, pp. 123 and 313. 


\section{RACIAL FACTORS IN DEMOCRACY}

From 308 to 297, Chandragupta was occupied with wars against the Seleucidae, whom he finally expelled from India. $\mathrm{He}$ was in constant touch with the outside world all through his reign.

During the reign of Bindusara (297-272) nothing of particular importance took place.

Asoka, the next king (reigned 272-232), was one of the two greatest Indian sovereigns, his rival being the Mogul Emperor Akbar the Great, in the Sixteenth Century, A.D. .Asoka's realms were very wide, for he ruled not only all northern India (including the Ganges, Jumna, and Indus valleys) but also a large amount of territory to the south of the Vinhya Mountains, including Kalinga, Madras, and the region around Pondicherry. His rule over these southward extensions of his kingdom was not, to be sure, so solid as that over the vast territories between the Hindu Kush and the Bay of Bengal, but nevertheless it was fairly well established, consisting either in direct personal control or in management through vassal kings whom he conquered.

To this powerful sovereign belongs the credit of rescuing Buddhism from the sea of schism into which it had fallen and of calling the third Buddhist council (244 B.C.). This council promulgated the canon law of Buddhism, solidifying its doctrines much in the same manner as did the council of Nicæa those of Christianity. Buddhism was established by Asoka as the state religion of India, and the king himself made a series of pilgrimages to the holy places of that faith.

Asoka kept in the closest relations with the 
Græco-Bactrian Kingdom. It was a period of steady cultural enrichment.

From about 250 B.C. to about 50 A.D. there is a period chiefly characterized by political turmoil, accompanied by excellent cultural accomplishment. In these characteristics it resembles the Fifteenth and Sixteenth Centuries A.D. in Italy. Hellenic tradition was kept vigorous throughout this period by various sorts of contact with the regions northwest of India. About I50 B.c. the Saka dynasty, of Parthian or Persian origin, established its power in northern India, bringing with it a renewal of Græco-Bactrian influences.

About the year 175 B.c. a tribe of nomads called variously Yue-Chih, Kushans, or Kwei-Schwang who had dwelt for centuries in the Chinese province of Kan-suh were pushed westwards by the ethnic restlessness of their kinsmen the Hiung-nu (Huns) and by the year I 50 B.C. they had taken up their residence in Bactria. For about a century they dwelt there, becoming thoroughly civilized and absorbing all that was best in Hellenic culture. They established a great kingdom, and about 40 B.c. they began, under the leadership of their king Kozulokadphises (or Kien-tsien-k'io) who had united all the Kushans under his power, to make good their mastery over Aryan India. The result was the erection of a huge Indo-Scythian kingdom which included all the regions between that of the Caspian Sea and that of central India. As is only natural in view of the great complexity of its inhabitants and of their history, this kingdom had a culture made up of elements derived from ancient Persia, from 
the Hellenized Bactrian kingdom, from the Hellenized Caspian region, from Aryan India, and from China. The greatest king of the dynasty was Kanishka (I23-I 53 A.D.). He, like Asoka, was a great patron of Buddhism. His conquests of Kashgar and Khotan were one of the means of establishing Indian influences in the high civilization that flourished in the Tarim basin, and they will be referred to later on at considerable length.

Between the years 73 and 102 A.D. India was brought into close trade-relations with the Roman empire, largely through the activities of a Chinese general named Pan Chao. Relations between China and Rome were also close, and, from its geographical position, it is clear that India must have had an important part in this trade. Roman gold poured into India to pay for Chinese and Indian silks, for gems, spices, and other products of the country. In the year 99 A.D. an embassy from India greeted the Emperor Trajan at Rome.

The result of all this intercourse was to establish an art-tradition which combined Græco-Roman technique with Indian Buddhist subject-matter. This school takes its name from Gandhara, whose sculptors were especially skilled in its production. The roots of the Gandhara school may be said to go back as far as 100 B.c. and its influence continued to about $45^{\circ}$ A.D., but its best period falls between the years 50 A.D. and 200 A.D. Its outstanding characteristic is a very pleasing combination of Græco-Roman decorative motives with all sorts of elements derived directly from India. There is a dignity, charm and beauty about the Gandhara 
art which is seldom equaled. ${ }^{29}$ Gandhara art shows the influence of the Græco-Roman tradition especially in such matters as the treatment of draperies, horses, and architectural details. One may see, for example, perfect Corinthian capitals with little Buddhas sitting among the acanthus leaves. In the treatment of the human form, also, the influence of Hellenic art is very strong; Gautama assumes an Apollo-like form and Kuvera (God of wealth) takes on the form of Zeus or Jupiter. Bodhisattvas and other minor figures in dress and attitude closely approximate late Greek and early Roman statues.

Into the matter of architecture it is not necessary for us to penetrate far. The credit for generalizing the use of stone for building purposes is usually attributed to Asoka, as is also that for originating the type of building later so widespread and called stupa or dagoba. In general terms a stupa may be defined as a large dome-like or pyramidal structure of stone with elaborate decorated galleries, enclosing walls, and gateways.

29 Barnett, 1914, passim.

Smith, I90I, p. III and passim. 1908, pp. 206-237 and passim. 1916, passim.

Minns, Ellis H.: Scytbians and Greeks. Oxford, 1913. Pp. 35-100 and passim.

Mookerji, Radhakumud: Indian Shipping. Bombay and London, 1912. Pp. 32-45.

Martin, Alfred W.: Great Religious Teachers of the East. New York, 1911.

Coomaraswamy, Ananda K.: The Arts and Crafts of India and Ceylon. London, 1913.

Binyon, Laurence: Painting in the Far East. New York, 1908.

Havell, E. B.: The Ideals of Indian Art. New York, N. D. Indian Sculpture and Painting. London, 1908.

Smith, Vincent A.: A History of Fine Art in India. Oxford, I9II., 


\section{RACIAL FACTORS IN DEMOCRACY}

\section{H. The Early Periods of Far Eastern Civilization}

It becomes necessary at this point to make a digression for the sake of giving a brief summary of early Chinese civilization, for without such a summary the significance of the culture of Khotan, to be considered presently, would not be clear.

Into the vexed question of Chinese origins I shall not venture to enter. It is to be supposed that, from a zoölogical point of view, the Chinese and other Far Eastern folk had connections with the rest of mankind; cultural connections, however, continued to be characterized by a mythical and legendary quality until a century or two before the Christian era. As in other cases, a Table of Culture-Periods is necessary.

\section{A TABLE OF THE EARLY CULTURE-PERIODS OF CHINESE CIVILIZATION 30}

Periods Dynasties Events Dates B.c.

Prehistoric. ...... A period of by no means low culture. Legendary persons of the "Culturehero" type........... Down to 2205

${ }^{30}$ It should be remembered that there were many minor states and a good many periods of confusion and strife between them, so that this Table should be regarded as representing only the main current of Chinese history. I have drawn upon the following for my material:

Hirth, Friedrich: The Ancient History of Cbina. New York, 1908.

Giles, Herbert A.: The Civilization of China. London, I9I I.

Bushell, Stephen W.: Cbinese Art. London. 2 volumes, 1904-06.

I have received help of various sorts from time to time from Dr. Roland Burrage Dixon, of Harvard University, and from Mr. Francis S. Kershaw of the Boston Museum of Fine Arts. 


\section{CONSTANTLY LINKED CULTURES 65}

Protohistoric Hia... The Emperor $\mathrm{Yu}$ and his successors divided China into nine provinces. It seems probable that there was a well-ordered society and the beginnings of arts and trades at this time... Shang or Culture already high.

Yin... Bronze, pottery and textiles well developed. Art and literature flourish....

Historic... Chou. . A period of unrest and confusion. Feudal conditions. Lao-tse (ca. 520), Kung-futse (ca. 55 I-475), and Mentse (ca. 372-289), were great leaders in thought. .

Han... A period of active relations with the West. Chinese power was extended as far as the Caspian Sea and even to the borders of the Roman Empire. There were frequent wars with the Hiung-nu (Huns) whom the Chinese finally overcame, annexing their territories. Relations with Khotan, and with other regions in the West were of the closest, political affiliations being strong, as well as purely cultural. Chinese influences in Korea and Japan were powerful, also.......... 221 B.C. to 201 A.D.

A period of wars and feuds between the three kingdoms, Chou, Wei and Wu

Chin Sui A period of obscurity marked by cultural growth, however..............
2205 to 1766

1766 to 1122

I1 22 to 255

$$
\text { A.D. }
$$

$201-265$

$265-619$ 


\section{RACIAL FACTORS IN DEMOCRACY}

\begin{tabular}{|c|c|c|}
\hline Periods & Dynasties & Events \\
\hline & Tang.. & $\begin{array}{l}\text { China controlled Khotan, } \\
\text { Kashgar and Tibet, ex- } \\
\text { tending her power once } \\
\text { more as far as the Caspian } \\
\text { Sea. Relations with India, } \\
\text { Persia and Constantinople } \\
\text { were close. The Turks } \\
\text { were conquered......... } \\
\text { A period of great cultural } \\
\text { development. Wars with } \\
\text { the Kin dynasty in the } \\
\text { North................. }\end{array}$ \\
\hline
\end{tabular}

Dates

B.c.

$619-907$

$960-1278$

All that is necessary for us to remember in connection with the present discussion is that by the Third Century B.c. China, which had originally been a small and unimportant inland state, had for many centuries been a great and very highly civilized power. Art, especially sculpture, literature, metallurgy, pottery-making, carpentry, agriculture, architecture, government, certain forms of mechanical contrivances (such as water-wheels for irrigation), and other elements of culture had long since been brought to a stage of perfection which has seldom and only recently been surpassed. We must, of course, look upon the complex of Indo-GræcoRoman civilization as a tremendous cultural totality, comprising influences full of irresistible power, but in so doing we must not forget that China embodied (and embodies) forces fully as impelling and quite as majestic.

The huge regions to the South of China proper (which did not get beyond the Hoang-ho or Yellow River till about II00 A.D.) were in the hands of a 
number of ill-defined non-Chinese peoples of whom the chief were the Thai. These people formed an empire of high culture with many Chinese and Khmer elements which flourished from about 500 B.c. to the Twelfth Century A.D. They were especially strong in Annam and Siam. It is to be understood that Chinese suzerainty and influence were matters of considerable reality. The Khmers of Cambodia will be discussed presently.

In the East, China influenced Japan through Korea from about the First Century A.D. onward. At that date Japan's population was a mixture of Malayan-Indonesian elements with an aboriginal stock called Ainu. The upper class seems to have been of continental origin (probably Korean). From about 300 B.c. to about 600 A.D. Japan was the seat of a Mongoloid culture from the mainland called Yamato. Its people had iron, wheel-made pottery, luxury-articles of bronze and copper, horses and rather elaborate bits and stirrups. Some glass beads were used. Influences from Handynasty China are numerous. ${ }^{31}$

In the North, in Mongolia, Tibet, and Siberia we have a tremendous stretch of territory which is, as yet, very little known. The inhabitants fall into two main groups. The first of these are the so-called Palæo-Siberians. They are an excessively old stratum of the population, and there are reasons for thinking that they and the American Indians have common ancestors. Their culture was never

a1 Munro, Neil Gordon: Prehistoric Fapan. Yokohama, I9II.

Brinkley, Francis: Fapan; its History, Arts, and Literature. Boston, 8 vols., $1901-02$. 
high. The second group is made up of Mongolian, Turco-Tartar, Indo-Germanic (i.e. Aryan), Nordic, and Alpine elements. The Scythians of the Caspian and Black Sea regions were an offshoot from them (about the Ninth Century B.c.). There were many tribes, all of them restless nomads. Even in the earliest discernible periods they used copper and bronze. Later they had a gradually elaborating iron-culture. They were agriculturists and irrigators, using horses very extensively, especially for drawing their huge wheeled tents. In the later periods they had cattle to some extent. One of the most troublesome tribes was that of the Hiung-nu or Huns. They caused the Yue-Chih to enter India and several centuries later themselves invaded Europe. There were constant contests for leadership among the tribes. The Scythians developed a very fine art which produced magnificent and beautiful objects of gold. Contact with China was more or less constant and generally partook of a hostile character. The Mongol empire of Kublai Khan in the Thirteenth Century A.D. is the culmination of Turco-Tartar-Mongol civilization. ${ }^{32}$

The state religion of China is a form of ancestorworship which embodies a ceremonial derived in part from surrounding regions. Reverence by the children for their parents and other forbears is a very important feature of Chinese and Japanese life and has been so for a great many centuries. The oldest deities were the gods of the sun, moon, planets, earth, and the various elements and forces

32 Minns, 1913, passim.

Carruthers, Douglas: Unknown Mongolia. London, 2 vols., rg13. 
of nature. Over these ruled a Supreme Being who abhorred wickedness and cherished goodness. For the most part these nature-gods (which so sharply recall those of Vedic India) were worshipped only by the ruling class and by the emperor or kings, the common folk contenting themselves with ancestor-worship and spirit-cults.

In the Sixth Century B.c. China's first great religious teacher, Lao-tse, flourished. The religio-philosophical system which he enunciated is called Taoism, from Tao (the Way). It is a concept of mystical beauty and of the loftiest moral purity, setting forth the proposition that for a human life the highest happiness possible was that of merging itself with the One, the Source of all life. To attain immortality and unity with the One the Tao must be followed, all fleshly grossness must be stripped from the soul, and perfect moral purity must be achieved. Like primitive Christianity, Taoism was at first simple, democratic and pure, but like that faith also, it was soon buried under a mass of additions and corruptions.

Partly contemporaneous with Lao-tse was the famous philosopher Kung-fu-tse or Confucius (ca. $55 \mathrm{I}-475)$. He was a high official in the kingdom of $\mathrm{Lu}$, but becoming disgusted by the frivolity of the court of Lu he set out on a long series of wanderings. While still in office he had introduced a new code of official integrity and probity. He was moved to do this by the prevailing state of China in his day, a condition in which great polish and advancement in material things existed side by side with equally great disorder, corruption, and degeneracy in political and moral matters. During his years 
of wandering, in which he traveled from one small state to another in northeastern China, he saw much to discourage him, and in his various writings we find the noble didacticism inspired by his experiences. ${ }^{33}$

Buddhism probably reached China about the First or Second Century A.D., bringing with it elaborate ritual, temples, and other elements unknown till then in China. It reacted upon Taoism in a way unfavorable to the latter. In the words of a Chinese writer (Chu Hsi) "Buddhism stole the best features of Taoism; Taoism stole the worst features of Buddhism. It is as though one took a jewel from the other, and the loser recouped the loss with a stone." Today both religions flourish and are much alike outwardly, especially as regards ceremonial, vestments, and so on.

During the Seventh Century A.D. the rulers of China showed an extreme catholicity in religious matters, for they not only permitted but even encouraged the introduction of new faiths. At this period Zoroastrianism, Mahommedanism, Nestorian Christianity, and Manichæism all entered China and took root more or less deeply there.

In almost every one of the many religions and philosophies here referred to one may perceive elements which resemble creeds in the West or which even seem clearly to have been derived from the West. When it is remembered that all these faiths became enwrapped in a mass of local and vulgar superstitions one can readily understand why

${ }^{33}$ Martin, Alfred W.: Great Religious Teachers of the East. New York, I9II. Ch. IV.

Legge, James: Confucius, in the Encylopædia Britannica, IIth Ed. 
today none of them is to be found in a state of pristine purity. Yet much, very much, of beauty, nobility, and lofty idealism may be found in the ancient systems of thought by him who seeks with sympathetic understanding. ${ }^{34}$

China recalls the West, especially India, in the main features of its social and political organization. There were four great classes, viz.: Scholars, Traders, Cultivators, and Laborers. In this we see a close parallel with the Brahmans, Kshattriyas, Vaisyas, and Sudras of Vedic India. The parallel continues in that, as in India, China was ruled by a hierarchy of officials for the village, region, province, and empire. China was peculiar, however, in that all officials had to go through a regular series of competitive examinations. Day-schools were present in every village in the land, and their teachers (belonging to the Scholar class, of course) were much honored by everyone. Indeed the educational machinery of China has for tens of centuries been one of the most extraordinary social institutions in the world. By means of a series of graded courses of study, supplemented by competitive examinations conducted with the utmost fairness, any man, however humbly born or however aristocratic, might rise to the most responsible positions in the state. Indeed, the poor were often given help from the public funds if they displayed ability. To the modern American or European mind the subjects taught seem to be somewhat absurd (consisting as they do of a sterile memorization of the Chinese classics), but that in no way impairs the admirable 4 Giles, 1911, pp. 57-80. 
qualities of the educational system itself, nor has it at all injured the character-building power of the education, for it has had such an effect upon the people as to make them in many respects the most moral and the most honorable in the world.

The family is the social unit. As regards matters which concern the family's relations with the world at large the father's will is supreme, even over those of the married sons. Within the home, however, the mother is the absolute mistress. This, combined with the filial devotion which all the children are bound to render to both parents and with the fraternal bonds which there have a strength and sweetness of which we are ignorant, makes for a family life of great beauty and purity. ${ }^{35}$

\section{The Civilization of Kbotan (Tarim Basin)}

The region whose extraordinary civilization we are now to study lies in the very heart of Asia. To the North are Siberia and Mongolia; to the East and South is Tibet; to the Southwest is the region of Kashmir; to the West are the Pamirs; and on the Northwest lies Russian Turkestan. The ancient Kingdom of Khotan lies on the southern side of the great Takla-makan Desert which occupies by far the greater part of the Tarim Basin. Though anciently well enough watered to maintain a high level of civilization and many prosperous cities, the Tarim Desert is now utterly arid, a sandcovered waste with only occasional oases, of which Khotan is one of the chief.

${ }^{35}$ Leong, Y. K.: and Tao, L. K.: Village and Town Life in Cbina. London, 1915. 


\section{A TABLE OF THE CULTURE-PERIODS OF KHOTAN ${ }^{36}$}

Periods

Remarks

Approximate

Dates

Protohistoric... Legendary period of the founding of Khotan.................

Indo-Chinese

Græco-Buddhist High and complex culture in Khotan............... I50 B.c. -300 A.D.

Chinese I..... Comparatively low but still complex culture................

Tibetan........ Still less perfect culture........

Chinese II..... No cultural improvement....... Mongol....... Revival of culture, with Mongol, Nestorian and perhaps Roman Catholic elements............

Decadence..... Due to dessication............

$$
\text { 250-150 B.c. }
$$

It should be understood that in the periods indicated in this Table the civilization of Khotan was diverse in its origins and character, never being exclusively affiliated with any single outside culture.

This complexity becomes very clear upon an examination of the mythology relating to the founding of the Kingdom of Khotan. According to one legend a son of Asoka left his father's realms and betook himself with some followers to the Tarim Basin where he set up a kingdom. At the same time a son of the emperor of China did the same,

${ }^{36}$ Material for this Table is drawn from:

Smith, I9II.

Rémusat, J. P. Abel.: Histoire de la ville de Khotan. Paris, 1820.

Stein, Sir M. Aurel: The Sand-buried Ruins of Khotan. London, 1903. Ancient Khotan. Oxford, 2 vols., 1907. Ruins of Desert Cathay. London, 2 vols., 1912.

Hedin, Sven: Tbrough Asia. New York, 2 vols., I899.

Chavannes, Edouard: Les documents chinois découverts par Aurel Stein dans les sables du Turkestan Oriental. Oxford, 1913. 


\section{RACIAL FACTORS IN DEMOCRACY}

establishing his kingdom close at hand. The two kings decided to fight for the supremacy, and in the struggle the Chinese king was the victor. Having vanquished his rival the Chinese sovereign built a capital city and other towns. Divine protection was vouchsafed his dynasty, for his son was nursed by a great breast and nipple that rose out of the earth at the behest of Vaisravana (alias Kuvera, God of Wealth). Somewhat different in detail is the version of the story contained in the Tibetan annals of Li-yul. This states that a young son of Asoka was nourished by a breast of earth, and that when he was weaned the god Vaisravana bore the child to the King of China who already had nine hundred and ninety-nine sons and who wished for a thousand. The king adopted the miraculous lad who, when he had reached the age of twelve, went off to the West and founded the Kingdom of Khotan. Later on he was joined by a man named Yasas and by seven thousand men from Asoka's kingdom.

Entirely legendary though these tales are, they nevertheless have value in that they indicate the composite character of the population and culture of Khotan even at that distant date. Today, there are present in that region Aryan, Tibetan, Mongol, Turkish, and Chinese elements.

In the Indo-Chinese or Græco-Buddhist period the civilization of Khotan assumed a highly interesting elaborateness. A considerable number of cities and towns grew up in the region around Khotan itself. The houses were made of wattle-and-dab, being held up by stout frames of timber. Probably 
they were similar to the contemporary houses in India. In the case of the more important residences the door frames, beams, brackets and so on were elaborately carved with decoration which recalls that in use during the Gandhara period in India. The purest Græco-Roman and purest Indian decorative motives blend together in an harmonious whole, enriched now and again by elements derived from the strictly religious art of the period. In the larger houses, which often had many rooms conveniently disposed and which often stood in their own grounds, the furniture was of a richness and beauty that accorded well with the general polish of life. Chairs, cupboards, bedsteads, and other such things were finely made and tastefully adorned with Gandhara.

The religious structures are of two sorts: cella and stupa. Of the two the former is the smaller and less pretentious; its construction is much the same as that of the houses, save for the fact that the stucco coating is often thicker and finer. In the case of the cella, notably those at Dandan-Uilik and at Niya, the decoration often takes the form of stucco reliefs so high as almost to be sculpture in the round. Throughout, the Græco-Roman technique blends harmoniously with Buddhist subjectmatter. ${ }^{37}$

The stupe are a good deal more elaborate in that they are of more solid construction (being made of adobe) and in that they have, besides the stucco

37 Stein, 1903; 1907; 1912; all passim.

Stein, Sir Aurel: Explorations in Chinese Turkestan. Smithsonian Report for 1903, pp. 747-774. Washington, 1903. 


\section{RACIAL FACTORS IN DEMOCRACY}

reliefs, a great variety of painted decoration. The documentary value of this last cannot be overestimated. Chronological determination is made easy not only by stylistic data derived from a study of the designs but also by actual manuscript documents of several sorts. Some of these are in Karoshthi (a form of Sanskrit and therefore to be linked with India) and others are in Chinese. For the most part the manuscripts are inscribed upon wooden tablets (though leather and silk documents are not wanting) which were sealed in a peculiarly efficacious manner. The curious thing about the seals is that while some of them are pure Chinese in character, others, perhaps on the same document, will possess an impression which shows Heracles, Athene, Zeus, or some other perfectly Hellenic figure. ${ }^{38}$

Of the fresco paintings those at Miran are the most interesting and representative. Like everything else in the Khotan region, they are of composite character. Associated documents show that the frescoes in question date from the first half of the Third Century A.D. There is a dado of angellike figures, beautifully painted with very rich coloring and an excellent sense of proportion and composition. Some of the winged figures have faces of an almost Semitic cast and their attitude of rapture is almost comical so closely does it resemble the pietistic paintings of Europe at a much later period. The figures have wide open eyes with no hint of the mongoloid characteristics about them, and their skin-color is rather fair, with rosy cheeks. In another part of the same fresco are scenes which ${ }^{38}$ Binyon, 1908, pp. 27-28. 
partake of the nature of genre paintings, for they permit us to form a detailed idea of the sort of life led in Miran at that time. Civilization was obviously not only of the highest but also of the most cosmopolitan description. One sees fine palaces, chariots with, three horses, elephants, stringed instruments resembling lyres, figures wearing Phrygian caps (as the Mithra-figures so common in the Roman Empire do) and statues which, because of the posture and because of the vine-leaf, resemble the Venuses of late Grecian art. Closely associated with all these things are others which speak eloquently of Buddhist influence. At Rawak, for instance, there are some colossal reliefs which, in the draperies and postures, resemble most intimately Roman statues of the late Republican and early Empire periods; yet here again the subject-matter is entirely Buddhist. ${ }^{39}$

In a word, the civilization of Khotan during its best days was a rich, diversified, and colorful cosmopolitan culture. In the succeeding periods geographical forces (especially dessication) combined with political and ethnic causes to overwhelm or corrode it. $^{40}$

\section{The Civilization of Fava and Cambodia}

The two civilizations we are about to consider now may be regarded as eastward ramifications of Indian civilization. The first attempt to colonize

39 Stein, I903b, Plate VI, Figure 12.

40 Remusat, 1820.

Yule, Sir Henry: The Book of Ser Marco Polo. Revised edition by Henri Cordier. London, 2 vols., 1903. 


\section{RACIAL FACTORS IN DEMOCRACY}

Java and Sumatra was made about 75 A.D. by a prince of Gujerat (Ganges valley) named Aji Saka. His effort, however, ended in failure. Nevertheless, even if we cannot assume the historicity of this expedition we may at least take it for granted that there was an eastward movement from the Asiatic mainland at that time, a movement which went on fitfully over several centuries and which was a part of the series of events to which the Oceanic area owes its pre-European population. ${ }^{41}$

There is, at any rate, a wholly indefinite period from about 100 A.D. to about 600 A.D. when events of the greatest ethnic importance must have been taking place not only in Java, Sumatra, Cambodia, and other parts of southeastern Asia, but also in Oceania. Though we know of not one definite fact, we may safely assume that Hindu (i.e. AryanIndian) influence was at least sporadically paramount and that mixture of its people with various other strata and groups of population was the cause of the mixed population which moved eastward into the enormous Oceanic area. ${ }^{42}$

In the Seventh, Eighth, and Ninth Centuries A.D. Buddhist Indian civilization definitely established itself in Java and Sumatra. This period

4 Havell, 1908, pp. Iro-113.

Smith, 191 I, pp. 26I-265.

Walcott, Arthur S.: Fava and ber Neigbbours. New York, 1914.

Dixon, Roland Burrage: Oceanic Mytbology. Boston, 1916. Pp. xii-xiii.

The Swan-Maiden Theme in the Oceanic Area. Holmes Anniversary Volume, pp. 8o-87. Washington, 1916b.

2 Ireland, Alleyne: The Far Eastern Tropics. Boston, 1905. Pp. $164-165$. 
witnessed its height, but it did not perish until

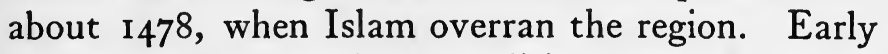
in the Seventh another expedition came from Gujerat in six large and one hundred small ships. The source from which this movement sprang indicates that it was a part of the proselytizing policy of the Mahayamist Buddhist Sect which was identified with the North and which carried Buddhism into China, Khotan, and Tibet. One may see exactly what sort of ships were used at two distinct places. One of these is the famous cave-site at Ajanta (Central India) and the other at the equally famous stupa of Borobudur in Java. From the representations of nautical activity at these two places we learn that the vessels had two or even three masts, square-rigged sails (sometimes supplemented by a jib), more or less semi-lunar hulls and one or two rudder-oars. Some of the ships were rowed, and a number of them closely resemble Roman ships, save for the fact that the outrigger (an Indonesian feature) is very common. The most surprising thing is the use of a magnetic compass in the shape of an iron (supposedly) fish floating in oil.43 With such an equipment as this it is not surprising that the expedition comprised military men, agriculturists, writers, artificers, horses, elephants, and workmen of all sorts.

The civilization thus established was exceedingly high. Indeed, it is often said that Borobudur, the finest of the many Buddhist temples built in Java at this period, is the most splendid florescence of

${ }^{43}$ Mookerji, I9I2, pp. 37-52.

Walcott, 1914, pp. 198-215. 
Buddhist art in the world. Although comparatively late, and although erected at a time when Buddhism was already dead in India, the great galleried pyramidal stupa of Borobudur and the art with which it is lavishly decorated preserve many of the best traditions of the Græco-Roman-Buddhist tradition. This is especially clear in the minor decorative motives and in the treatment of bodies, draperies, and ships. Prambanam and some of the other Javanese sites display a general decline both in rsthetic feeling and in technical mastery, and they lack the chaste elegance and finish of detail which make the Borobudur sculptured reliefs not only one of the largest works of art in the world but also one of the most gorgeously, flamboyantly beautiful. The voluptuous sensuality of the Prambanam sculptures may be traced back to the more restrained sensuousness of those at Borobudur. This falling-off in general fineness of tone may be attributed to several causes, but perhaps one of them was a cessation in the series of cultural stimuli that had been transmitted from India, a cessation coupled with and intensified by a grossness derived from the lower-cultured indigenes (probably negroids, in part, at least) in whose midst the migrants from Aryan India had established themselves.

In Cambodia, in the region of the Mekong River, there was a very similar civilization, also of Indian origin, at least in part. From about I 200 B.c. there are various notices in Chinese writings of a region called Fu-nan which seems to have been more or less the same as the modern Cambodia. At this early period the population was partly Malay and prob- 
ably partly negroid, with a low culture. The people worshiped snakes and similar things. About $43 \mathrm{I}$ B.c. a prince named Prea-thong, son of the king of Intakpath (Delhi), came to the lower Mekong valley. $\mathrm{He}$ beat the indigenes in a series of battles and founded a kingdom called Crung-Campuchea. After replacing the old snake-worship with Vedic Brahmanism, he founded a number of cities.

Our knowledge of the history of Cambodia is based on the inscriptions found at the various sites. These fall into two groups: the Sanscrit (Pali) texts which are often metrical accounts of various happenings and which show influences from both North India and South India; and the Khmer inscriptions which are chiefly lists of gifts made to the gods and to the ruler. Khmer, being an agglutinative language, stands in sharp contrast to the highly inflected Sanscrit speech.

It seems fairly clear that there were several succeeding waves of migration from both North India and the South. Early in the Fifth Century A.D. a Kashmir prince named Guna-Varman became ruler over all Cambodia. The power of the Varman dynasty lasted up to the end of the Seventh Century, and it seems to have included in its domains at least some parts of Borneo ${ }^{44}$ for some important inscriptions that have been found there seem to indicate this. The Fifth, Sixth, and Seventh Centuries were very brilliant in Cambodia. Culture was high in all respects, and the religion was Vedic Brahmanism. In 638 Buddhism was introduced from

4 Aymonier, Étienne: Le Cambodge. Paris, 3 vols., 1900-04. III, p. 404. 
Ceylon and it soon became a formidable rival of Brahmanism. The Eighth Century was a comparatively reticent period, but the years between about 800 and about 1200 witnessed the final and greatest florescence of the Khmer civilization. To this period belong the marvelous structures at Angkor-Thom (Royal City) and Angkor-Vat (Royal Pagoda) and at other sites. In this age, as in the earlier one, all Cambodia was united under one sovereign. The final cause of the decline of this great civilization was the attacks by the Siamese and the Annamese in the Thirteenth and Fourteenth Centuries.

The buildings of Angkor are made of brick and of various sorts of stone. In arrangement they display an extraordinary regularity and also a fondness for gigantic proportions. Some of the chief architectural features are large water-courts surrounded by majestic colonnaded galeries, most of them with V-shaped corbelled roofs; great pyramidal structures with steep stairways bordered by highly decorated balustrades; huge human faces sculptured in high relief on great pillars and columns. These things, together with a variety of minor ones, notably certain dwarf-like figures which have the function of caryatids, superficially resemble things to be discussed in connection with some of the Central American cities. The wealth of decorative ornament, whether representational or conventional, at Angkor is truly amazing. Almost every available inch of flat surface was encrusted with decoration which for grace, variety and delicacy of execution has seldom been rivaled and never equaled, save by 
the best Gothic work and by some of the decorations to be seen in the French palaces of the Seventeenth and Eighteenth Centuries. In the many miles of moldings, borders, door-frames and lintels in the Cambodian ruins there is a vast mine of material from which modern architects could, if they but would, derive many hints for adornments and so enable themselves to give the public a vacation from their everlasting use of long-ago outworn classical ornaments.

Although chiefly an Aryan-Indian civilizat on (with a number of survivals from the Græco-Roman tradition) the Angkor culture shows some influences derived from China. They are but slight, however, being strongest in the paintings with which some of the buildings are decorated. Everywhere the same chastity, purity, and elegance is observable. ${ }^{45}$

45 Aymonier, 1900-04, II, pp. 123-126.

Fournereau, Lucien, and Porcher, Jacques: Les ruines d'Angkor. Paris, 1890. Pp. 48-51; 189-192.

Moura, L.: Le royaume de Cambodge. Paris, 2 vols., 1883. 


\section{PARTIALLY ISOLATED AND COMPLETELY ISOLATED CULTURES}

\section{A. Partially Isolated Cultures}

7 HERE are and have been a number of cultures in the world which have at one time or another been in contact more or less close and definite with the highest cultures of the world but which have, for long periods of time, had little or no steady stimulation from such a source. Such cultures, as I say, are rather numerous. A few of them are: the Caroline Islands, with vestiges of a fairly advanced culture of the agricultural variety and of people skilled in making edifices of stone; ${ }^{1}$ Hawaii, with its wellorganized government, its remarkable agrarian and irrigation system, its well-planned stone temples, its gorgeously beautiful feather- and basketry-work and other cultural elements of similar grade; ${ }^{2} \mathrm{New}$

1 Christian, F. W.: The Caroline Islands. London, 1899.

Volkens, G.: Ueber die Karolinen Insel Yap. Verhandlungen Gesellschaft für Erdkinde, XXVIII. Berlin, 190I.

Kubary, J. S.: Ethnographische Beitrage zur Kentniss des KarolinenArcbipel. Leiden, 4 vols., 1889-92.

2 Bastian, Adolf: Zur Kentniss Hawaiis. Berlin, 1883.

Liluokalani, H. M. Queen: Hawaii's Story. Boston, 1898 .

Alexander, W. D.: A Brief History of the Hawaiian People. New York, 189I. 
Zealand, with its extraordinary art and its skilfully constructed houses and boats and its intricate and beautiful tatu designs; ${ }^{3}$ the Oceanic area as a whole for its remarkable ability in nautical construction and in various sorts of artistic and social achievements; ${ }^{4}$ the Canary Islands with their curious culture which seems, in some respects, to be the half-developed embryo of a true civilization and which presents tantalizing resemblances to CrôMagnon, Nordic, Carthaginian, and Berber culture; ${ }^{5}$ all of these, and doubtless other regions (such as Benin and Madagascar) present cultural characteristics that might well be used to illustrate the re-

Fornander, A.: Account of the Polynesian Race and the Ancient History of the Hawaiian People. London, 3 vols., 1878-85.

Brigham, William T.: Hawaiian Featherwork. Memoirs of the Bernice Pauahi Bishop Museum, I, Part I. Honolulu, 1899.

Churchill, William. The Polynesian Wanderings. Carnegie Institution of Washington, publication No. 134. Washington, I9I I.

3 Thompson, A. S.: Story of New Zealand. London, 1859.

Smith, S. Percy: Hawaiki. Christchurch, New Zealand, 1904.

Hamilton, Augustus: Maori Art. Dunedin, New Zealand, 1896.

White, John: The History of the Maori. Wellington, New Zealand, 4 vols., 1886-89.

Cowan, J.: The Maoris of New Zealand. Wellington, I9ro.

4 Edge-Partington, James: Albums. Manchester, England, 2 vols., 1890. Albums; Second Series, Manchester, 1895. Albums; Third Series, Manchester, 1898.

Kraemer, Augustus: Der Haus- und Bootbau Samoas. Berlin, 1905.

- Millares Cubas, A.: Historia general de las islas Canarias. Las Palmas, 10 vols., 1893-95.

Berthelot, S.: Antiquités canariennes. Paris, 1879.

Sergi, G.: The Mediterranean Race. London, 1901.

Espinosa, Alonso de: The Guanches of Tenerife. Translated and Edited by Sir Clements R. Markham. Hakluyt Society, London, 1907.

Hooton, E. A.: Preliminary Remarks on the Archeology and Physical Antbropology of Tenerife. American Anthropologist (N. S.), XVIII, pp. 358-365, 1916. 
sults of partial isolation and sporadic contact, but our purpose will be equally well served by employment of the Rhodesian civilization, about which a few remarks will be made. ${ }^{6}$ The wrangling (for it is nothing else) about the age of the culture does not concern us. It is well to note, however, that Randall-Maciver emphasizes the indigeneity of the culture and that Hall insists upon its extraneous origin.

Be all that as it may, the ruined cities of Zimbabwe, Nanatali, Dhlo-Dhlo, Kami, and so on show us a culture which may be described as a modestly developed civilization. The buildings are finely made of well-laid stones, the walls often being tastefully decorated by means of patterns composed of stones set criss-cross or zig-zag in the masonry. There is a very strong tendency toward orderly arrangement and careful "city-planning," high walls and tall conical towers being important features of the architecture. The people had not only weapons of iron, but also tools and ornaments of iron, copper, and bronze. It is significant that finds have been made of Persian faience of the Thirteenth or Fourteenth Centuries, of Arabian glass of about the same date and of Chinese porcelain of the Sixteenth Century. These discoveries certainly prove that some sort of connection existed with the outside

- I have tried to steer clear of the numerous controversial points raised by the two chief authorities on this subject. To do so is difficult, and the unprejudiced outsider like myself finds it a matter for regret that the two gentlemen involved have permitted themselves to become rather bitter.

Randall-Maciver, David: Mediceval Rbodesia. London, 1906.

Hall, Richard N.: Pre-Historic Rhodesia. London, 1909. 
world at the dates in question. Whether other classes of ruins and remains belong to an initial period preceding or to a decadent period following the florescence of the Zimbabwe culture is not clear. It is quite plain, however, that foreign contact must have had at least a measure of stimulating results and that the modern culture of the district is far lower than it once was. Consequently $\mathrm{Hall}$ is justified in his dictum that:

"... The Zimbabwe culture but shared the inevitable fate of all civilizations imported on to the African Continent whether at Carthage or Egypt. So long as the foreign connection was sustained, so long did they exist, but on the connection being disturbed ... subsequent oblivion was their fate." 7

\section{B. The Isolated Cultures of America}

As I have already explained above (page 22), there is absolutely no trace of any connection between the high cultures of the American continent in the Pre-Columbian period and those of the outside world at any period. The only points of cultural contact between the American continent and the rest of the world are two in number and they do not, in either case, involve any high culture. It will be well, however, to mention them. One is in that portion of our continent which we call Alaska and in the coastal regions south of it. There one finds cultural and somatological facts which link the tribes in that region with those in neighboring por-

7 Hall, r909, p. 479. 
tions of Asia, and one finds in the same regions the evidence which proves the fundamental zoölogical unity of American man with Asiatic man, a unity already referred to. ${ }^{8}$ The other point of contact is to be discovered in the extreme southern part of the continent of America, where certain cultural features suggest that some slight influences may have been exerted by people in the Oceanic area. ${ }^{9}$ The chief of these features is the use of a plank boat not unlike those in the Oceanic area.

In spite of all this, it is quite clear that, save for the zoölogical connection already mentioned, American high cultures have nothing to do with Asiatic civilization or with any other.

It is no part of my purpose to trespass on the ground already ably covered by many writers, and, in a general way, by Beuchat and Wissler. ${ }^{10}$ There-

8 Dall, William H.: On the Succession in the Shell-Heaps of the Aleutian Islands. Washington, 1877. On the Remains of Later Pre-Historic Man ... in the Catbarina Archipelago, Alaska. Smithsonian Contributions to Knowledge, XXII. Washington, 1880. The Native Tribes of Alaska. Proceedings of the American Association for the Advancement of Science (1886), pp. 363-38I, I886.

Dixon, Roland Burrage: The Independence of the Culture of the American Indian. Science (N. S.) XXXV, pp. 46-55. 1912.

Hrdlićka, Aleś: 1912, 1917, 1917b. The Peopling of America. Journal of Heredity, VI, pp. 79-9I. Washington, I9I 5.

Laufer, Berthold: Plate Armor in America. American Anthropologist (N. S.) XV, pp. 96-97. 19r3.

${ }^{9}$ Cooper, 1917.

Friederici, Georg: Die Scbiffabrt der Indianer. Stuttgart, 1907. Ein Beitrag zur Kentniss der Trutzwaffen der Indonesier Suedseevoelker und Indianer. Baessler-Archiv, VII. Leipzig, 1915.

Graebner, Fritz: Die melanesische Bogenkultur und ibre Verwandten. Anthropos, IV, pp. 726-780; 998-1032. 1909.

10 Beuchat, Henri: Manuel d'archéologie américaine. Paris, 1912.

Wissler, Clark: The American Indian. New York, 1917. 
fore I shall not touch upon the cultures of any of the regions north of Mexico, east of the Andes or south of the Maule river in central Chile. Instead, my purpose will be that of outlining the chief characteristics of the civilizations of Middle America (Mexico and Central America) and of the Andes (Peru, Bolivia, and Ecuador) so as to show what they accomplished in spite of their isolation and what they lacked on account of their isolation.

The archæology of Northern Mexico furnishes us with a link between the comparatively low cultures to the North and the high ones to the South. These high cultures must be defined in turn; they are: (a) Middle American Civilizations (i.e., those of Mexico, Yucatan, Guatemala, and Central America); (b) those of the Isthmus and of Colombia; (c) those of the Andes. I shall consider each in turn.

Middle American Civilizations. The oldest stratum of high culture is found all over Middle America and signs of it appear in both North America and South America. For the sake of convenience it is called by the arbitrary name of Archaic Culture. This culture is represented by a class of human figurines of varying excellence, the crudest being those which seem, on stratigraphic and geographical grounds, to be the oldest. We now know that the people of the Archaic Culture should be given the credit for the originating and distribution on the American continent of the arts of agriculture, pottery-making, loom-weaving, and plastic representation of life-forms. ${ }^{11}$ In the later periods of

"Spinden, Herbert J.: Notes on the Archeology of Saloador. American Anthropologist (N.S.) XVII, 434-450. 1915. The Origin and Dis- 


\section{RACIAL FACTORS IN DEMOCRACY}

the Archaic Culture the conditions were such that life had already taken on considerable cultural complexity. Elaborately decorated textiles and pottery were made, and doubtless such things as houses and language had attained a commensurate development. The date at which the Archaic Culture found its inception cannot even be conjectured, but it is now fairly clear that the end had come by 200 A.D., if not by 100 B.C. The reasons for this assertion and for its vagueness will be made clear presently.

The succeeding period in Middle America saw the rise, florescence, and decay of a civilization which was very deeply rooted in the Archaic Culture. It is generally called the "Old Empire" of the Maya. The rise of the Old Empire took place in an indefinite period which ran from about i IO B.c. to about 200 A.D. The first date is that incised in a crude chirography upon the earliest dated piece of stone-work in America. ${ }^{12}$ The second date is that

tribution of Agriculture in America. International Congress of Americanists, XIX, pp. 269-277. Washington, 1917. Ancient Civilizatious of Mexico and Central America. New York (American Museum of Natural History), 19i7b.

Means, Philip Ainsworth: Las relaciones entre Centro-América y SudAmérica en la época prebistórica. Boletín de la Sociedad Geográfica de Lima, XXXIII, pp. 151-170. 1918.

12 This is the Tuxtla Statuette (now in the National Museum at Washington). The date, in the Maya hieroglyphic system, is equivalent to II3 B.c., being 8.6.2.4.17. in that system of notation. Consult: Spinden, 1917b, p. 130.

Morley, Sylvanus Griswold: An Introduction to the Study of Maya Hieroglypss. Bureau of American Ethnology, Bulletin 57. Washington, 1915. Pp. 194-96.

Holmes, William H.: The Oldest Dated American Monument. Art and Archæology, III, pp. 275-278. 1916. 
of the beginning of the historic period of the Maya civilization. We have, besides the Tuxtla Statuette, at least two other dated objects from this period, and probably more will be discovered as time goes on.

The period between I IO B.c. and 200 A.D. may be regarded in two ways: Either we may consider it as the final phase of the Archaic Culture or we may look upon it as the first phase of the historic period; either course is justifiable. It is significant that, though the chirography of the Tuxtla Statuette inscription (and of the two other early ones) is crude, the system of notation is that same tremendously intricate affair which was used by the Maya in their later periods. So excessively elaborate is the hieroglyphic system there represented that it implies many generations, if not many centuries, of preliminary growth prior even to the incompleted stage exampled by the Tuxtla Statuette. ${ }^{13}$ So far none of the initial forms which must have intervened between the first rock-scratchings and the inscriptions referred to here have been found. Yet they must exist, and it is important that they be unearthed. ${ }^{14}$ It is to be noted that at Copan, one of the great cities which I shall presently describe, even the oldest monuments (dated about 250 A.D.) are obviously posterior to the erection of the enormous artifical mound whereupon the city stands into

13 Means, Philip Ainsworth: History of the Spanish Conquest of Yucatan and of the Itzas. Papers of the Peabody Museum (Harvard University), VII, p. 3. Cambridge, Mass., 1917.

14 What I am about to say is based entirely upon information which I owe to Professor Marshall Saville, of the Museum of the American Indian, New York City. 


\section{RACIAL FACTORS IN DEMOCRACY}

its present form. Owing to the fact that earthquakes and the action of the Copan river (which swirls by the site) have torn away one whole side of this mound we are able to see that there are within it the vestiges of several smaller mounds, a number of ancient plazas (with drains and stone pavements) and old structures of one sort or another, all of which were later covered up so as to enable the inhabitants to build the present gigantic mound. In this submerged mass of material, representing probably as much as ten generations of previous growth, must search be made, if it is to be made anywhere, for the initial steps that led to the final development of the Maya hieroglyphic system. The obstacles, both physical and financial, are, of course, tremendous. But until they are surmounted we must postulate a long period of growth during which Copan (and other cities) was occupied by a people who had a steadily maturing Archaic Culture and a constantly developing knowledge of mathematics and of architecture. When that period of cultural adolescence was completed (about 200 A.D.) Maya culture entered definitely upon the stage to which the name "Old Empire" is arbitrarily applied.

The "Old Empire" of the Maya people occupied that territory which is now included in the southern part of the Mexican state of Campeche, in the state of Chiapa, and in the northern portions of the Republic of Guatemala. It stretched from the Laguna de Terminos on the Northwest to the Golfo Dulce on the Southeast, being chiefly concentrated in the valley of the Usumacinta river. The period at 
which the civilization in question flourished was about $200-640$ A.D. ${ }^{15}$

Although we use the term "Old Empire" to designate the civilization of this period, we really know nothing whatever about the form of government that prevailed, beyond the mere fact that there was plainly an aristocracy (probably sacerdotal) which is often represented in the carvings. There were a great many cities, large and small, throughout the region specified. Some of the chief ones, with their dates, were: Tikal (210-600); Palenque (240-420); Copan (250-540); Naranjo (310-550); and Quirigua $(450-600)$. For the sake of showing what the general material culture was, I will say something about each of them.

Tikal, the longest-occupied of these great cities, is situated northeast of Lake Peten (Northern Guatemala). It is an assemblage of ruins occupying a territory nearly a mile square. Like nearly all the Middle American cities, Tikal is built in such a way that all the chief edifices form themselves in groups around plazas and courts. The groups of buildings, in turn, are so disposed as to resemble acropoleis separated from one another by empty spaces. Structures fall into two classes, religious and secular, which have many architectural features, especially those involved in constructional engineering, in common. The temples are built upon very high and

15 Morley, 1915, pp. 2-3.

Spinden, 1917b, pp. 130-132.

Means, 1917, p. 3.

Joyce, Thomas A.: Mexican Arcbaology. New York, 1914. Pp. 199-203. 


\section{RACIAL FACTORS IN DEMORCACY}

steep pyramidal substructures having a magnificent flight of steps, flanked by elaborate balustrades, at one side. The purpose of the substructure (which had as many as nine terraces) was to give a look of grandeur to the building. Surmounting the pyramid was a comparatively small tabernacle or shrine, ranging from about thirty-five to about eighty feet square. The outstanding features of the shrines were the enormous thickness of their walls and the symmetrical disposal of the narrow chambers with their V-shaped corbelled ceilings. The first was made necessary by the custom of erecting tremendously tall and very heavy roof-combs over the building so that the total height of the structure often reached 180 feet and more. The Maya, wonderful builders though they certainly were, had not learned (nor did they ever learn) enough to build loftily without unduly thickening their walls. On account of this lack the wall-covered space is in several instances five or six times greater than the space taken up by the chambers themselves. In the secular buildings, probably the residences of the great, there is no such discrepancy for the reason that height was not so much sought after. Instead, the rooms are more numerous and broader, but they still bear a general resemblance to those in the temples in that they are much longer than wide (the width scarcely ever exceeds eight feet, for structural reasons), in that the arrangement is usually symmetrical and in that the $\mathrm{V}$-shaped corbelled ceiling, often supplemented by well-finished beams of sapote wood. The doorways, especially the wider ones, usually have lintels of wood tastefully carved 
with delicate skill. There were not only ventilationholes but even true windows, and benches of stone were present in most of the domiciliary structures.

We may picture Tikal, then, as a large city with scores of sumptuously built temples, palaces, and other buildings. The great and the powerful lived in splendor the architectural part of which bears a very striking superficial resemblance to that of Angkor, as the reader will have noted. I suppose that the two totally unrelated places had another thing in common, namely the comparative squalor in which their proletariat must have lived, for, in the absence of proof to the contrary, we must assume that the masses lived meanly in lowly huts of wattle-and-dab which have long since vanished..$^{16}$ The material of the other buildings was a rubblelike concrete faced with beautifully matched stones.

Palenque is chiefly distinctive on account of the beauty and delicacy of the reliefs in the Temple of the Foliated Cross (so called on account of the magnificently intricate cruciform design which forms its chief adornment. The treatment of the human anatomy and of drapery at Palenque is not surpassed at Angkor nor in Egypt. The costumes shown are of the greatest complexity, a short, shirt-like garment being supplemented by a tremendous headdress of feathers, neck-, breast-, and wrist-ornaments of stones, and elaborate sandals.

Copan, with its wonderful artificial mound, has

16 Tozzer, Alfred Marston: A Preliminary Study of the Prebistoric Ruins of Tikal. Peabody Museum, Memoirs, V, No. 2. Cambridge, I911.

Maudslay, Alfred Percival: Biologia Centrali-Americana. London, 4 vols., 1889-1902. 


\section{RACIAL FACTORS IN DEMOCRACY}

already been referred to. Like Tikal and Palenque, indeed like all Maya cities, it is an assemblage of plazas and courts with appropriate buildings. The most imposing extant monument at Copan is that known as the Hieroglyphic Stairway, an immense flight of steps the risers of which bear a long and elaborate inscription. ${ }^{17}$ The other monuments at Copan are of commensurate development.

The art of Naranjo, though not so delicate, is fully as gorgeous as that at Palenque. The use of the soaring roof-comb is important here, as it is at Tikal, and of course the inevitable V-shaped vaulted rooms are present in the buildings. ${ }^{18}$

As to the architecture at Quirigua we have but little knowledge, for almost no traces of it are left. The stone-carving there, however, is almost the finest in the Maya area. Exceedingly involved with overlaid ornament though they are, the designs, both anthropomorphic and hieroglyphic, of the great monolithic sculptures at that site, possess a beauty which grows upon one as he studies them. The finest are those known as "The Great Dragon," Stela A, and Stela D. ${ }^{19}$ Strange and overorna-

17 Gordon, George Byron: The Ruined City of Copan. Bulletin of the American Geographical Society, XXXI, p. 39 ff. New York, 1899.

Saville, Marshall H.: Explorations on the Main Structure at Copan, Honduras. Proceedings of the American Association for the Advancement of Science, XLI, pp. 271-275. 1892 .

${ }_{18}$ Maler, Teobert: Explorations in the Department of Peten, Guatemala. Peabody Museum Memoirs, IV, No. 2. Cambridge, Mass., 1908.

19 Maudslay, 1889-1902.

Holmes, William H.: The Great Dragon of Quirigua. Art and Archxology, IV, pp. 269-280. $1916 \mathrm{~b}$.

Lummis, Charles F.: Where the Stones Come to Life. Art and Archæology, IV, pp. 281-289. 1916. 
mented though these will seem to those who are unaccustomed to the profoundly symbolical flamboyancy of Maya art, they yet possess a technical perfection and an indescribable air of self-assurance that mark them as the product of an extraordinary people.

My purpose in thus indicating very briefly some of the chief features of a few of the Maya cities has been that of making clear the more striking aspects of that great civilization. Maya art as a whole is a subject so complex as to make it impossible for one to present it adequately in a brief space. Modern knowledge of the main currents of its development are largely due to one man. ${ }^{20} \mathrm{He}$, Spinden, has already traced its rise, its growth, its decay through the stultifying influences of conventionalization and sacerdotal domination, its fall, its period of abeyance, and its reawakening. Similarly, other writers have worked out the highly involved systems of hieroglyphics and chronology used by the Maya. ${ }^{21}$ Of these things we need say nothing more than that they betoken a great intellectual development and an equal sense of beauty and order.

For several centuries, up to about 600 A.D., this "Old Empire" civilization of the Maya flourished in colorful splendor. To the North and West other civilizations throve, in greater or lesser degree connected culturally with that of the Maya.

${ }^{20}$ Spinden, Herbert J.: A Study of Maya Art. Peabody Museum Memoirs, VI. Cambridge, Mass., 1913.

21 Morley, 1915.

Bowditch, Charles P.: The Numeration, Calendar Systems and As tronomical Knowledge of the Mayas. Cambridge, Mass., 1910. 
The Zapotec culture (in the modern Mexican state of Oaxaca) was clearly a direct derivitive from Maya culture. It had the same sort of hieroglyphs and its cities, especially Monte Alban, presented the same characteristic grouping of pyramidal structures about plazas and courts. Though strikingly like Maya art proper, that of the Zapotecs was distinctly less finished in point of execution than its prototype. This does not mean that it was less elaborate, for that was not the case; indeed, it may be said that the tendency of Maya art toward over-decoration was, in Zapotec art, carried to extremes. ${ }^{22}$ Presumably, on the ground of our present imperfect information regarding this culture, the earlier stages of it are represented by the sites called Monte Alban and Xochicalco. At least it is they which most closely approximate the Maya cities. The sites of the sort represented by Mitla are to be linked, not with the Maya, but with the Aztecs, with whose state they were probably associated, as I shall remark later on. ${ }^{23}$

Of the other lesser cultures which flourished at this period (i.e. about the Fifth, Sixth, and Seventh Centuries A.D.) that of the Totonacs in the modern state of Vera Cruz was one of the chief. Its chief

22 Spinden, 1917b, pp. 139-145.

Joyce, 1914, pp. 172-179.

${ }^{23}$ Holmes, William H.: Archaological Studies among the Ancient Cities of Mexico. Field Museum. Chicago, 1895-97.

Breton, Adela C.: Some Notes on Xocbicalco. University of Pennsylvania. Philadelphia, 1906.

Peñafiel, Antonio: Monumentos del arte Mexicano antiguo. Berlin, 3 vols., 1890 .

Batres, Leopoldo: Clasificación del tipo étnico de las tribus zapotecas. Mexico, 1890. Exploraciones de Monte Alban. Mexico, 1902. 
site was the celebrated city of Papantla where the vestiges of a wonderful pyramid of five terraces, each with a row of window-like niches, may still be seen. The stone-carving of the Totonacs not only closely resembled that of the Mayas, but even rivaled it in excellence. Two forms of stone objects, both the vehicle for intricate yet tasteful ornamentation, were peculiar to these people. One was a yokeshaped stone the use of which is unknown; the other is a paddle-shaped affair, also of stone and equally obscure as to its purpose. Like the culture of the Zapotecs, that of the Totonacs in its earlier stages was contemporary with and very closely allied to the Maya civilization. But it outlived the latter, and in its final phases was closely associated with the Aztec state.

In Mexico proper a high culture was in existence from about the middle of the Third Century onwards. This was the civilization of the Toltecs, which is today typified by Teotihuacan, Cholula, Colhuacan, Tula, Azcapotzalco, and other sites. ${ }^{24}$ Beginning as an offshoot of the "Old Empire" civilization of the Mayas, the Toltecs went through a good many cultural, tribal, and political vicissitudes about which we are not yet fully informed, and survived, though in a much modified state, down to the beginning of the Aztec state about 1325,

24 Spinden, I917b, pp. $145-160$.

Joyce, 1914, pp. 7-12.

Beuchat, 1912, pp. 258-26r.

Peñafiel, $\mathbf{1} 890$.

Peñafiel, Antonio: Teotibuacan. Mexico, 1899.

Nuttall, Zelia: The Terra Cotta Heads of Teotibuacan. American Journal of Archæology, II, pp. 157-178; 318-330. 1886. 


\section{IOO RACIAL FACTORS IN DEMOCRACY}

the date of the founding of Tenochtitlan (now Mexico City). It is by no means certain whether all the cities identified with the Toltec culture throve contemporaneously. Tula, for example, is stated by the ancient manuscript histories of the people themselves to have flourished only from 752 to 1064 , yet we are certain that the Toltec civilization was both older and more lasting than this would indicate. We can only assume, therefore, that the various cities had their periods of greatness and decay. ${ }^{25}$ Taken as a whole, the Toltec culture may be looked upon as a bond, both cultural and chronological, between "Old Empire" times and "New Empire" times in Middle America. It was a culture which grew up upon the foundations laid down by the very early Archaic Culture already described, and it was frequently invaded, usually from the North, by new tribes of low culture but of virile and adaptable temperament. Such an one is the invasion of the Aztecs, who, when they reached the valley of Mexico about II70, were a rude hunting folk; but they, like the other tribes that came with them or followed them, were intelligent, and they soon became as civilized as the Toltecs. To these constantly recurring influxes of new stock we may confidently attribute the changes that took place in Toltec culture during the centuries of its existence.

25 Wissler, 1917, pp. 270-273.

Tozzer, Alfred Marston: The Domain of the Aztecs. Holmes Anniversary Volume, pp. 464-468. Washington, I9I6.

Orozco y Berra, Manuel: História antigua de la conquista de Mexico. Mexico, 4 vols., 1880 .

Brasseur de Bourbourg, C. E.: Histoire des nations civilisées $d u$ Mexique et de l'Amérique Centrale. Paris, 4 vols., 1857-59. 
To return now to the Maya themselves is necessary. After a period of cultural relapse and lethargy which lasted roughly from 700 to 1000 , they entered upon a new period (called the "New Kingdom" or the "League of Mayapan") in which cultural development was in a high stage. The cause of the degeneration must, in part at least, be attributed to an increase in the unhealthfulness of the climate (never oversalubrious, even at the best of times). ${ }^{26}$ It is possible, also, that unskilful agricultural methods led to agrarian troubles and forced the people to seek out new fields for planting. A lack of care about crop-rotation, fallowing and so on could easily lead to a state of soil-exhaustion. Whatever the cause, the fact is clear enough that the Maya, during the period named, were wandering about from place to place, unable to settle down and in a comparatively low cultural plane. They changed their habitat gradually from that which they had had in "Old Empire" days to a new one in the northern part of the peninsula of Yucatan. There, sometimes between 960 and I000 A.D., the revival of cultural activities overtook them. ${ }^{27}$ Once again they became great builders, artists, sculptors, and handicraftsmen. Here, on account of the

${ }^{20}$ Huntington, Ellsworth: Civilization and Climate. New Haven, 1915. Pp. 242-243.

${ }^{27}$ Spinden, 1917b, pp. 132-134.

Joyce, 1914, pp. 199-218.

Beuchat, I912, pp. 427-437.

Means, 1917, pp. 6-8.

Ancona, Eligio: Historia de $r$ ucatan. Barcelona, 4 vols. 1889. I, pp. 85-III.

Molina Solis, J. F.: Historia del descubrimiento y conquista de Yucatan. Merida, Yucatan, 1897. 
greater amount of accurate information derived from the writings of the Mayas themselves, we begin to know something about their government. ${ }^{28} \mathrm{~A}$ triune league was formed, about 1000 , and it dominated the whole of northern Yucatan. The cities which composed it were: Uxmal, ruled by the Xiu family; Mayapan, governed by the Cocom family; and Chichen Itza, the seat of the Itza. The ruler of each of these great cities was called halach uinic (real man); his power may be likened to that of the petty sovereigns who made up the so-called Holy Roman Empire, and like those sovereigns, each halach uinic had a number of vassal lords (called batabs) who governed such minor towns as Labna, Kabah, Ake, T'hoo (Merida), Hochob, and so on. All the rulers, of whatever rank, were hereditary. Under the League of Mayapan there prevailed a high order of administrative efficiency, accompanied by a remarkable degree of justice, public morality, and refinement. ${ }^{29}$

During the period of the League of Mayapan (about 1000 to 1200 ) architecture, both in the major and in the minor cities, reached its zenith. In general the types of buildings were the same as those which were used in "Old Empire" times, the two categories of religious and secular buildings being as sharp as formerly. But the decoration was less florid and more severe. The V-shaped vaultings, roof-combs, pyramidal substructures and ${ }^{28}$ Brinton, Daniel Garrison: The Maya Cbronicles. Philadelphia, 1882.

Tozzer, Alfred Marston: The Cbilam Balam Books. . . . International Congress of Americanists, XIX, pp. 178-186. 1917.

${ }^{29}$ Morley, I915, pp. 8-10. 
other features continued in use. The characteristic decorative styles used on the buildings of this period were designs made of closely serried files of rounded pilasters set into the stone façade (this is seen at its best -at Labna) and the elaboration of an anthropomorphic mask-motive (notably at Chichen Itza). Mural painting was common, also. ${ }^{30}$

In short, the civilization of the League of Mayapan was one distinguished by an ample and mature development of many of the best arts man has invented. It is to be greatly regretted that the vain-glorious ambition of the halach uinic of Mayapan precipitated, about 1200 , a period of strife and bloodshed. This hohenzollern was a man named Hunnac Ceel who was jealous of the splendor and felicity of cities which were not his and set about getting them. To support his pretensions he imported from Mexico a force of Nahua (i.e., Toltec) mercenaries to whom, either willingly or no, he gave up the city of Chichen Itza. While war and rapine were abroad throughout the land that capital (between about I 200 and about 1442) went through a period of development which was very brilliant. Great temples with columns having capitals formed like feathered serpents, huge tlachtli or hand-ball courts, caryatid-like figures (resembling those men-

30 Spinden, 1913.

Joyce, 1914, pp. 319-354.

Maudslay, 1889-1902.

Thompson, Edward H.: Archaological Researches in Yucatan. Peabody Museum Memoirs, III, No. I. Cambridge, Mass., 1904.

Breton, Adela C.: The Wall-Paintings of Cbichen Itza. International Congress of Americanists, XV, pp. 165-169. 1906b. 


\section{RACIAL FACTORS IN DEMOCRACY}

tioned in connection with Angkor) and other features, all of Mexican (i.e., Nahua) origin, were introduced; painting became more splendid and varied than ever before, but sculpture took on a grossness and a flamboyancy eloquent of a decline in xsthetic delicacy.

About 1442 the inevitable disintegration took place. In the chaotic period that followed Yucatan was filled with many petty warring states, none of them equal in culture to the batab towns of the League period. In this degenerate condition the peninsula continued till the Spanish conquest. ${ }^{31}$

From about 1325 when, as has been said, the city of Tenochtitlan (now Mexico) was founded, to the time of the Spaniards' arrival the valley of Mexico and many regions far and wide throughout Middle America were under the rule of the Aztecs. At first, to be sure, their power was limited to their reedy isle in the Lake of Tezcuco, but very rapidly their dominion grew. By means of raft-like affairs made of wattle-work on which earth was placed they covered a large part of the surface of the shallow lake with floating gardens which, in time, became fixed by reason of the fact that the roots of the plants growing upon them reached down through the interstices and fastened themselves into the soil of the lake-bottom. Their government was an excellently planned one headed by a war-chief whose position was often transmitted upon hered-

31 Brinton, 1882 .

Means, 1917, pp. 16-23.

Landa, Diego de: Relación de las cosas de Yucatan. Edited by Brasseur de Bourbourg. Paris, 1864 . 
itary principles. He was aided in the government by an official who, though a man, had the curious title of Snake-woman. There was an immense and oppressive priesthood which administered the rather repulsive and sanguinary religion..$^{32}$ Aside from agriculture, war was the chief interest in the lives of the Aztecs. Tribute, territorial aggrandizement, and the desire of getting sacrificial victims in the shape of prisoners of war seem to have been the chief motives. Warriors who distinguished themselves in battle were invariably rewarded by an advance in rank, and in this we see something approaching modern democratic ideas, as we do also in the agrarian and social systems of the time.

Outwardly life was as gay and as polished as ever. Art was exceedingly brilliant, both in sculpture and in painting. There were plenty of sports, the game of tlachtli (handball) being particularly popular. The purpose of the game, however, was undoubtedly more that of ceremony than that of having a good time. Feathered-serpent columns, caryatid-like figures and other architectural features, which have been mentioned as occurring in the Nahua period of Chichen Itza, were elaborated by constant use. Pottery was well made and gaily decorated. The feather-work of all sorts is only rivaled by that of

32 Joyce, I914, chapters IV-VII, inclusive.

Spinden, 1917b, pp. 18I-220.

Beuchat, 1912, pp. 297-393.

Bandelier, Adolph F.: On the Distribution and Tenure of Lands. . . among the Ancient Mexicans. Peabody Museum. Cambridge, Mass., 1878. Social Organization and Mode of Government of the Ancient Mexicans. Peabody Museum, Cambridge, Mass., 1879. 


\section{IO6 RACIAL FACTORS IN DEMOCRACY}

Hawaii, and it was much more diverse in form than the latter. ${ }^{33}$

Enough has now been said to give the reader a general impression of the civilization that prevailed in Middle America during the centuries that preceded the coming of the Spaniards. I have tried to make it clear that it was a culture both complex and brilliant. Although such matters as the hieroglyphic- and calendar-systems are far too technical to be discussed here, nevertheless they should be mentioned for the reason that they indicate a great intellectual ability on the part of the people of those times, as do also the various preconquests manuscripts that have come down to us. Remarkable and fascinating as all this is, however, those cultures had extraordinary lacks and imperfections an account of which will be given later on.

We may dispose of the rest of the Middle American

${ }^{33}$ Nuttall, Zelia: Standard or Headdress? Peabody Museum, Papers, I, pp. 5-68. Cambridge, Mass., I 888.

Diaz del Castillo, Bernal: $A$ True History of the Conquest of New Spain. Translated and edited by Alfred Percival Maudslay. Hakluyt Society, London, 5 vols., 1908-16.

Bancroft, Hubert Howe: Native Races of the Pacific States. San Francisco, 5 vols., 1883. V, pp. 359-483.

Alva Ixtlilxochitl, Fernando de: Histoire des Cbicbimèques. Edited by $\mathrm{H}$. Ternaux-Compans. Paris, 1840 .

Alvarado Tezozomoc, Fernando de: Crónica Mexicana. Edited by Manuel Orozco y Berra. Mexico, 1878-81.

Sahagún, Bernardino de: Historia de la conquista de Mexico. Mexico, 1829.

Clavigero, Francesco Saverio: Storia antica del Messico. Cesena, Italy, I78I.

Anonymous Conqueror, The: Narrative of Some Tbings of New Spain. Translated and edited by Marshall H. Saville. Cortes Society, New York, 1917. 
regions down as far as the Isthmus of Panama by saying that in all of them the earliest cultural stratum is that of the Archaic Culture, and that in the later deposits objects are found which can be linked more or less closely with one or another of the civilizations which we have already considered.

Isthmian and Colombian Civilizations. The civilization of the Isthmus of Panama seems chiefly remarkable on account of the presence at various sites, notably the vicinity of the Laguna de Chiriquí, of a culture which is obviously an especially advanced variety of the Archaic Culture. At Chiriquí, and in many other Panamanian sites, there is none of the crudeness and colorlessness to be seen in the artifacts which mark those of the earliest strata in Mexico. Indeed, Chiriquian art, whether in pottery figurines or vessels or in gold-work, is of a complicated type which is eloquent of an inchoate symbolism and an adolescent stage of general cultural development. Yet, because only the more attractive and striking specimens are selected by writers for illustrative purposes, we must postulate or assume the existence of somewhat humbler varieties of the Archaic Culture, though it is probably true that the crudest varieties are nowhere present on the Isthmus. There is an enormous diversity, both in earthenware and in gold-work, as regards form, color, degrees of conventionalization, and elaborateness. Concerning the architecture of the Isthmian culture we know nothing. For the purposes of the present discussion, then, the Isthmus of Panama may be considered as the seat of a cultural link binding Middle America to 


\section{RACIAL FACTORS IN DEMOCRACY}

South America, just as the Isthmus itself binds the two parts of the continent. ${ }^{34}$

Nor is there anything in Colombian civilization that need detain us much longer. Suffice it to say that the archæology of the coast reveals the presence of artifacts which may be assigned to an offshoot of the Isthmian culture. With these are sporadic instances of trade-objects from the interior or from down the coast. In the highlands of Colombia there are clearly two strata of culture. One, the earlier, is represented by a site called San Agustin, on the right bank of the upper Magdalena river. Save for the fact that it is clearly related with the Peruvian culture known as Tiahuanaco we know, as yet, nothing about it save that the erectors of the San Agustin remains were skilled in the use of stone. The later stratum is that to which the well-known Chibcha nation belonged. This was a small but well-organized state which centered about the plain of Bogotá. All about them were savage tribes with whom they had constant wars, but the Chibchas themselves maintained an orderly government and a material culture distinguished by the use of good pottery, stone buildings, and cotton cloth, as well as a richly ceremonial religion. At the time of the Spanish Conquest the Chibchas had

"Holmes, William H.: Ancient Art of the Province of Cbiriqui. Report of the Bureau of American Ethnology for 1884-85, pp. 3-187. Washington, 1885 .

MacCurdy, George Grant: A Study of Cbiriquian Antiquities. Memoirs of the Connecticut Academy of Arts and Sciences, III. New Haven, Conn., rgri.

Joyce, Thomas A.: Central American and West Indian Arcbaeology. New York, 1916. Pp. 90-152. 
spread northwards into the Isthmian region to a certain extent. ${ }^{35}$ Here again, as on the Isthmus, the culture is an intermediate one, or rather a series of intermediate ones, of no particular importance as far as the present theme is concerned.

Andean Civilizations. As in Middle America there formerly existed a cluster of related civilizations which varied somewhat in point of proficiency, so was there, in the Andes (Ecuador, Peru, and Bolivia), another group of cultures similarly linked to one another. What the relations between the two sets of civilizations were is the first point that must be made clear.

I have already pointed out that from an unknown antiquity the various parts of Middle America were occupied by one variety or another (and often by several) of the Archaic Culture which, though not itself a high culture, contained the germs and incipient forms of art and industry, forms which

25 Restrepo Tirado, Ernesto: Los 2uimbayas. Bogotá, I912.

Codazzi, A.: Antiguedades indígenas. Bogotá, 1863.

Restrepo, Vicente: Los Cbibcbas, Bogotá, 1895.

Stuebel, Alphons and Uhle, Max.: Kultur und Industrie der Sud-Amerikaniscbe Voelker. Berlin, 3 vols., 1889-90.

Stoepel, K. Th.: Archaological Discoveries in Ecuador and Soutbern Colombia . . . and the Ancient Stone Monuments of San Agustin. International Congress of Americanists, XVII, pp. 251-258. 1912.

Preuss, K. Th.: Reisebrief aus Kolombien. Zeitschrift fuer Ethnologie, XLVI, pp. 106-113. I914.

Uribe Angel, Manuel: Estado de Antioquia. Paris, 1885.

Uricoechea, Ezequiel: Memorial sobre las antiguedades neo-granadenses. Berlin, 1854. Gramática de la lengua Cbibcha. Paris, 1871.

Markham, Sir Clements R.: The Conquest of New Granada. London, 1912. $\mathrm{Pp}, \mathrm{II}-48$.

Joyce, T. A.: Soutb American Arcbaology. New York, 1912. Pp. 8-46. 


\section{IIO RACIAL FACTORS IN DEMOCRACY}

themselves constitute the material side of a respectworthy inchoate civilization. Undoubtedly the time that elapsed between the first stirrings of the upward movement betokened by the intensifying complexity of each succeeding phase of the Archaic Culture and the final phases of that culture, exemplified by the Chiriquí culture, was not short. On the contrary, it must, in the nature of things, have been slow, gradual, and logical. It is significant, therefore, that the very crudest types of Archaic Culture objects are not characteristic of Chiriquí. Still more significant is it that only the highest types of that culture are to be found in the Andes, both on the littoral and on the highlands. This situation suggests that the Archaic Culture was already an old and comparatively complex affair by the time it reached Chiriqui and that it was somewhat more so by the time it reached the Andean littoral. ${ }^{36}$

Means, 1918, pp. 160-16r.

Uhle, Max: Die Muschelbuegel von Ancon. International Congress of Americanists, XVIII, pp. 22-45. 1912 .

Dorsey, George A.: Archaological Investigations on the Island of La Plata. Field Museum, Chicago, rgoI. Pp. 266-267.

Putnam, Edward K.: The Davenport Collection of Nazca and other Peruvian Pottery. Proceedings of the Davenport Academy of Sciences, XIII, pp. 17-40. Davenport, Iowa, I914.

Saville, Marshall H.: Antiquities of Manabi, Ecuador. New York. 2 volumes. II, Plates XLII-XLV, Inclusive, and Plates LXXXIII$\mathrm{XCV}$, Inclusive. 1907-10.

Hrdlićka, Aleś: Some Results of Recent Antbropological Exploration in Peru. Smithsonian Miscellaneous Publications, Vol. 56, No. 16. Washington, I9I I. Plate I.

It has been my good fortune to be able to study the Archaic Culture in Peru by means of examining the traces of it that may be seen in various collections in that country and in Bolivia. Chief of these are: The Collection of Dr. Javier Prado y Ugarteche; that of Dr. Julio C. Tello (both in Lima); that of Dr. Victor Eguiguren, (at Piura); that of Sr. 
Yet the presence of the Archaic Culture in Peru and Bolivia is very real, and it is noteworthy that it immediately preceded the growth of the higher cultures in that region.

All this leads me to believe that the Andes received their population from Middle America at a rather indefinite period the end of which was probably roughly contemporaneous with the time at which the Archaic Culture in Yucatan was metamorphosing itself into the true Maya civilization of the "Old Empire." In other words, it seems clear that, through quite a lengthy period, tribes and clans of Archaic Culture people from Central America kept drifting down the Pacific and Atlantic seaboards into South America. Undoubtedly these accidental and vague migrations kept up until the Spanish conquest, finding, in later centuries, a corollary in an equally unpremeditated series of contrary north-bound roving movements. Perhaps the underlying motive in all this is that of trade, or that of seeking new fields for tillage or new lands for hunting. Whatever the cause may have been, it is now clear enough that by about 200 A.D. the Archaic Culture began to merge into the first of a series of subsequent cultures. ${ }^{37}$

It is highly unfortunate that the Andean folk never followed the example of their Middle American kinsmen in inventing a system of hieroglyphical

don Luis Elias y Elias; (at Morropón); that of Sr. Mayor don Federico Diez de Medina (in La Paz); and that of Sr. don Agustín de Rada (at La Paz).

${ }^{37}$ Means, Philip Ainsworth: Realism in the Art of Ancient Peru. Art and Archæology, VI, pp. 235-246. 1917b. 


\section{RACIAL FACTORS IN DEMOCRACY}

notation. Because of their failure to do so, modern investigators have to wring their historical information from data gathered from other sources than documentary ones. The chief sorts of facts available are those derived from archæology and from a critical study of mythology, legends, and folklore. Analysis of all of these, and especially intensive research into the artistic development of the people, has made it reasonably clear what the main trend of historical development must have been in pre-Columbian times. Without plunging into the technical basis of our knowledge, I will outline its content.

The Andes having been peopled in a haphazard manner by two ethnic streams, one following the Pacific shore and the other the eastern watershed and littoral of the South American continent, two groups of cultures came into existence. One was that which, for want of a better term, is usually designated the Chimu-Nasca culture; the other is best called Early Tiahuanaco. The seat of the former was the Andean littoral, from the Gulf of Guayaquil down to northern Chile. The seat of the other was in the basin of Lake Titicaca in the Andean highlands. Because of the disjointedness which characterizes the habitable portion of the Andean coast, the Chimu-Nasca culture varies considerably from valley to valley; but everywhere there may be seen a fundamental unity which marks it as the product of a close-knit ethnic group. At first the Chimu-Nasca culture was exceedingly isolated, as was also the Early Tiahuanaco. But as the former rose gradually from the plane of the 
Archaic Culture it spread, by reason of trade and of war, further and further inland. Inevitably it collided, in the course of years, with the Early Tiahuanaco culture. Of the two the Chimu-Nasca civilization was unquestionably the higher. It had wonderful cities composed of well-built houses of adobe; its art, especially that of pottery-making, was complicated and rsthetically admirable; its social organization and general development were good. Early Tiahuanaco culture was far behind that of the coast in point of xsthetic advancement, but this disadvantage was offset by the proficiency which it had acquired in the use of stone as a building-material and in the rudiments of stone-carving, metal-working and wood-carving. When the two cultures met, therefore, each had good qualities which the other lacked. It is not surprising, then, that the reaction to their contact took the form of a general progression in culture in which both participated. In Later Tiahuanaco civilization we see very, clearly the influence of rich and colorful coast designs in the ceramics; the architecture has improved for the same reasons; metal-work (copper, bronze, gold, and silver) is very diverse in form and ornament; ornamental stone-cutting has become intricate and luxuriant. In short, the civilization of the so-called "Tiahuanaco Empire" was a high, varied and synthetically compounded culture. Little wonder is it, therefore, that we find it presently becoming imperial in its ambitions and spreading its influences far and wide, not only in the highlands, its peculiar habitat, but on the coast as well. Vestiges, more or less numerous and definite, of it are 


\section{II4 RACIAL FACTORS IN DEMOCRACY}

found all the way from San Agustin in Colombia down to northwestern Argentina and northern Chile. On the coast traces of it appear on the coast of Ecuador and all along the Peruvian littoral. ${ }^{38}$

${ }^{28}$ Joyce, 1912, pp. 168-192.

Beuchat, 1912, pp. 569-587.

Wissler, 1917, pp. 23 I-233.

Markham, Sir Clements R.: The Megalitbic Age in Peru. International Congress of Americanists, XIV, ii, pp. 521-529. 1904. A Comparison of the Ancient Peruvian Carvings on the Stones of Tiabuanaco and Chavin. International Congress of Americanists, XVI, pp. 389-395. 1908. The Incas of Peru. New York, 1910. Pp. 21-47.

Baessler, Arthur: Ancient Peruvian Art. New York, 3 vols., 1902-03.

Bandelier, Adolph Francis: The Indians and Aboriginal Ruins near Chachapoyas, Nortbern Peru. New York, 1907. The Islands of Titicaca and Koati. New York, 19ro. The Ruins of Tiabuanaco. Worcester, Mass., I9II.

Berthon, Paul: Etude sur le précolombien du Bas-Pérou. Paris, 191 r. Boman, Eric: Antiquités de la région andine. . . . Paris, 2 vols., 1908.

Cobo, Bernabé: Historia del Nuevo Mundo. Edited by Marcos Jimenez de la Espada. Seville, 4 vols., 1892.

Debenedetti, Salvador: Influencias de la cultura de Tiabuanaco ... en el noroeste argentino. Buenos Aires, I9I2.

Gonzalez de la Rosa, Manuel: Les deux Tiabuanaco . . International Congress of Americanists, XVI, pp. 405-428. 1908.

Means, Philip Ainsworth: An Outline of Culture Sequence in the Andean Area. International Congress of Americanists, XIX, pp. 236-252. 1917c. A Note on the Guarani Invasions of the Inca Empire. Geographical Review, IV, pp. 482-484. I917d.

Montesinos, Fernando: Historia antigua del Perú. Edited by Marcos Jiminez de la Espada. Madrid, 1882.

Nordenskiöld, Baron Erland: Arkeologiska Urdersokningar in Perus och Bolivias. Stockholm, 1906. The Guarani Invasion of the Inca Empire. Geographical Review, IV, pp. 103-121. 1917. Die oestliche Ausbreitung der Tiabuanacokultur ... Zeitschrift fuer Ethnologie. Berlin, I917b.

Oyarzún, Aurelio: Contribución al estudio de la cioilización peruana sobre los aborigines de Cbile. International Congress of Americanists, XVII, pp. 354-397. I9I0.

Posnansky, Arturo: Una metropolí prebistórica en la América del sud. Berlin, 19r4. 
In the opinion of some writers this spread of the Later Tiahuanaco civilization brought about a definite interruption in the Chimu-Nasca culture. At one time I shared this opinion ${ }^{39}$ but I can do so no longer in the face of data which I gathered during my last trip in Peru. It now seems to me plain that the sole result of the spread of Tiahuanaco culture from the highlands down to the coast was that of elaborating the adobe architecture of the latter region with forms borrowed from the stone architecture of the highlands. There were also various minor contingent transmittals of cultureelements at the same time. There were, however, no profound political, tribal, and permanent innovations. After the Tiahuanaco culture itself declined (probably in the Tenth Century), small and lower cultures sprang up throughout the mountains, but the Chimu-Nasca civilization continued its course with but slight abatement in its cultural vigor. In the course of time one of the numerous low-cultured tribes which succeeded the Tiahuanaco people in possession of the highlands began to form a sort of hegemony over the other tribes in its vicinity, and, in the course of time it became the leader of a considerable confederacy. This tribe

Polo, José Toribio: La piedra de Chavin. Boletín de la Sociedad Geográfica de Lima, IX. 1899.

Reiss, Wilhelm, and Stuebel, Alphons: The Necropolis of Ancon. Berlin, 4 vols., I $880-87$.

Squier, E. George: Peru. . . . New York, 1877.

Uhle, Max: Pachacamac. Philadelphia, 1903. Tipos de civilizacion en el Perú. Boletín de la Sociedad Geográfica de Lima, XXV. 1910.

39 Means, Philip Ainsworth: A Survey of Ancient Peruvian Art. Transactions of the Connecticut Academy of Arts and Sciences, XXI, pp. 315-442. New Haven, Conn., 1917e. 


\section{II6 RACIAL FACTORS IN DEMOCRACY}

was that of the Incas, a word which, in common parlance, is often made to include all the ancient peoples of the Andes. As a matter of fact, the Incas were in reality no more than a tribe particularly able in governmental affairs, by reason of which ability they gradually transformed themselves into a royal clan holding dominion over the great stretch of territory included in the modern republics of Peru, Ecuador, Bolivia, northern Argentina, and northern Chile. This was their status in the days of the four last Inca sovereigns (Viracocha, about 1370-1425; Pachacutec, about I425-I478; Tupac Yupanqui, about 1478-1488; and Huayna Capac, $1488-1525) .{ }^{40}$

Taken as a whole, the Andean civilizations present several aspects marked by special excellence. One of these is their architecture, especially that of late Inca times. Nowhere in the world may the perfect dignity and impressiveness of quite unadorned masonry be better understood than at Machu

40 Gonzalez de la Rosa, Manuel: Ensayos de cronología incana. Revista Histórica (Lima) IV, trimestres i and ii. 1909.

Cavello Balboa, Miguel. Histoire du Pérou. Edited by H. TernauxCompans. Paris, 1840 .

Cieza de Leon, Pedro de: Chronicle of Peru. Edited by Sir Clements Markham. Hakluyt Society, London, 1883.

Garcilasso de la Vega, el Ynca: Royal Commentaries of the $Y_{n c a s .}$ Edited by Sir Clements Markham. Hakluyt Society, London, 2 vols., I869-7I.

Jimenez de la Espada, Marcos: Tres relaciones de antigüedades peruanas. Madrid, 1879.

Riva-Agüero, José de la: La bistoria en el Perú. Lima, 1910. Elogio del Inca Garcilaso. Revísta Universitaria de la Universidad Mayor de San Marcos (Lima), XI, pp. 335-412. I9I6.

Sarmiento de Gamboa, Pedro: History of the Incas. Edited by Sir Clements Markham. Hakluyt Society, London, 1907. 
Pichu, Pisac, Cuzco, Cañar and scores of other sites in the Andean highlands. Late Inca masonry depends upon no flamboyant decoration carved upon it for its grandeur and austere, somewhat lugubrious, magnificence. It would be a great outrage upon good taste if any meretricious prettiness, however delicately executed, were added. Tier upon tier, row upon row, the fine substantial walls of Inca buildings rise, defying time, earthquakes, and human vandalism. Inca masonry is something which modern architects would do well to study. ${ }^{41}$ Hardly less remarkable, though very different, are the other styles of architecture in ancient Peru, notably those of the Chimu-Nasca folk and those of the Tiahuanaco culture.

In the making of textiles, both of cotton and of wool, the ancient Andeans displayed a conspicuous dexterity. Garments, hangings, satchels, slings, and many other things were woven with a fineness which modern looms seek in vain to rival. Good coarse cloth for rougher usage was also manufactured. The designs were rich in color and harmoniously diversified in form. ${ }^{42}$

Like the textiles, the pottery of these people was wonderful in shape, color, and pattern. The Chimu-

11 Bingham, Hiram: The Wonderland of Peru. National Geographic Magazine for April, 1913. Washington, 1913.

Wiesse, Carlos: Las civilizaciones primitivas del Perú. Universidad Mayor de San Marcos. Lima, 1913.

Gonzalez Suarez, Federico: Historia general del Ecuador. Quito, 7 vols., 1890-1903. Atlas arqueológico. Quito, 2 vols., 1892.

${ }^{42}$ Crawford, M. D. C.: Peruvian Textiles. Anthropological Papers, American Museum of Natural History, XII, Part iii. New York, 1915. Peruvian Fabrics. Anthropological Papers, American Museum of Natural History, XII, Part iv. New York, I9r6. 


\section{II8 RACIAL FACTORS IN DEMOCRACY}

Nasca ware, which went through many phases, both chronologically and geographically, was especially excellent for realism in its earlier and more northerly varieties and for richness of tint in its somewhat later and more southerly forms. The later Inca pottery was very graceful in shape, but the painted decoration tended to be sombre and geometric. Tiahuanaco ware was much like that of the coast, from which it borrowed many features. ${ }^{43}$ In the allied arts of metal-working (in copper, bronze, silver and gold) the Andeans displayed a proportionate ability. Their feather-work, though less intricate than that of the Mexicans, was admirable, ponchos, towering headdresses and kindred objects being made with the gayly colored plumes of the tropical birds which abound in those parts.

In the matter of social organization the arrangements perfected under the Inca régime in the Andes were particularly excellent. In order to understand them properly it is necessary to go back a little into pre-Inca times. In the period between the decline of the "Tiahuanaco Empire" (during

43 Baessler, 1902-03.

Reiss and Stuebel, 1880-87.

Joyce, 1912, pp. 193-215.

Beuchat, 1912, pp. 636-692.

Means, 1917e.

Uhle, I910; 1903.

Berthon, I9II.

Tello, Julio C.: Los antiguos cementerios del valle de Nasca. Proceedings of the Second Pan-American Scientific Congress, I, pp. 283-29I. Washington, 1917.

Urteaga, Horacio: Bocetos bistóricos. Lima, 1914. Pp. 85-90.

Eaton, George F.: The Collection of Osteological Material from Macbu Piccbu. Memoirs of the Connecticut Academy of Arts and Sciences, V. New Haven, Conn., rg16. 
which, undoubtedly, there had been some sort of central or supreme government) and the rise of the Inca Empire, the disruptive influences of geographical environment in the Andes were enabled, through the absence of artificial couteracting forces, to assert themselves. Consequently, throughout the Andean highlands the people split up into small communities, each possessing a valley or a part of a valley, and all separated from one another by the high mountain-ranges. These communities were called ayllus. They were made up of a number of families to the heads of which the arable land was allotted annually by the elders of the ayllu. Pasturelands for the flocks of llamas and vicunas and the forest-lands when there were any were held in common by the ayllu. Government was distinguished by the same informal and complete democracy that characterized primitive China and the early days of mankind in general. It is not wonderful that conditions so idyllic did not last long. After a while it became customary for the ayllus to appoint an officer called sinchi to lead them in their wars against one another. At first the sinchi, like the Roman dictator in the days of Cincinnatus, was merely a temporary leader appointed to fend against special dangers. As time went on, however, the sinchi became more and more definitely a fixture. At the same time ayllus tended to draw together into strong confederacies; then came a period in which the confederacies contended bitterly for supremacy. The history of the Incas is merely that of one ayllu which, by reason of its cleverness and perseverance, first made its sinchi 


\section{RACIAL FACTORS IN DEMOCRACY}

permanent chief over the six other ayllus in the Cuzco valley, then, with the confederacy thus formed, overcame its rival confederacies to South and North. That done, the Incas, by the time Viracocha assumed the scarlet feather-diadem of sovereignty, found themselves a royal family with dominion over a large and well-organized kingdom. Though determined to make their city, Cuzco, the center of a vast and highly centralized state, the Incas were sagacious enough not to arouse needless antagonism among their new vassals and subjects by introducing radical modifications in the structure of society. Instead, they took over the already established system of ayllus and, altering here and there when necessary, molded it to their requirements.

The underlying purposes of the Inca administration were that all people should be given definite work to do for society and that no one should suffer the discontents which arise from idleness, want and overwork. To serve those aims labor was organized so as to be plentiful but not arduous, and there were ample provisions for play-times and festivities as well as for food and clothing. The state, that is the Inca sovereign and the official class made up of Incas-by-blood and of Incas-by-privilege, supervised every phase of social existence and saw to it that all was well. To do so, they found that a very carefully planned administrative mechanism was necessary. The old ayllu was now called a pacbaca and was made up of 100 families over whom an official designated by the heads of families (with the sovereign's approval) was placed, being given a title which means "village-supervisor." The pa- 
chacas, in turn, were arranged in groups of ten, each group being under the control of a higher official chosen from the village-supervisors. The next subdivision of the state was the province, usually conterminous with a formerly independent confederacy or kingdom (such as that of the Titicaca Basin or the kingdom of the Chimu on the coast). The head of it was generally its old chief who, having been made an Inca-by-privilege, ruled over his old dominions in the capacity of a mediatized prince. Over him was a general overseer of the blood royal who had jurisdiction over four or five provinces and who was responsible to the person of the sovereign.

In addition to these purely administrative posts there were a lot of auxiliary offices of one sort or another. Such were concerned with the roads, bridges, inns, post-runners, royal farms, fisheries, with the flocks belonging to the Inca or to the priests of the Sun, and so on. The people themselves were divided up into age-categories to each of which occupations proportionate to their strength were apportioned. Women held an honored position in society, being practically the equals of men. It was a happy time in the history of America. Peace, plenty, playfulness, jollity, and justice reigned throughout the broad lands swayed by the Inca rule from Cuzco. Though some of the coast people were, at times, immoral to an extreme, the Incas never permitted anything of the sort. To us, the incestuous marriages of the last sovereigns seem repulsive, but they were a late development, being the outcome of an oddly snobbish desire on the part of the royal family to keep its blood uncontaminated. 


\section{RACIAL FACTORS IN DEMOCRACY}

Though without writing, the Andeans had a well-regulated solar calendar based on accurate observations of the sun's movements. Their year was liberally sprinkled with holidays on which they celebrated such events as the harvest, the solstices, and the coming of age of the youths. There were songs and dances in which all the men and women took part. At the court, which was usually at Cuzco but which accompanied the sovereign wherever he went, always being housed in finely built palaces of stone richly furnished with exquisite hangings, carved stools, splendid gold, silver, copper, and pottery vessels and many ornaments in stone, bronze, and kindred objects, there were performances of a sort which contained the germs of incipient drama, as well as the more usual rhythmic dances and pantomimes. ${ }^{44}$ In short, it was a society which fell not very far short of being a civilization of the highest sort.

The American Civilizations as a Whole. In the rapid review of the American civilizations which I

44 Garcilasso, 1869-7I.

Sarmiento, 1907.

Markham, I910, pp. 159-172.

Wiesse, 1913, pp. 88-121, 171-198, 239-267.

Joyce, 1912, pp. 99-116.

Beuchat, 1912, pp. 597-609.

Riva-Agüero, 1910, pp. 113-162.

Sancho, Pedro: An Account of the Conquest of Peru. Translated and edited by Philip Ainsworth Means. Cortes Society, New York, 1917.

Cunow, H.: Die soziale Verfassung des Inkareiches. Brunswick, 1898. Saavedra, Juan Bautista: El ayllu. La Paz, 1909.

Belaunde, Victor Andrés: El Perú antiguo y los modernos sociölogos. Lima, 1908.

Uhle, Max: Los origenes de los Incas. International Congress of Americanists, XVII, pp. 302-353, 1910b. 
have just given, it has been my aim to present some of the more striking good qualities that anciently prevailed in American cultures. Properly to appraise those cultures, however, it is needful to record their shortcomings as well as their superiorities.

Practically every lack on the part of the American cultures would have ceased to exist very shortly had they been, as some have wished to claim that they were, in relationships with the outside world. Let us choose, to prove this point, the case of mechanical contrivances. The most important single element in any piece of mechanism is the wheel. This is equally so of the wheeled vehicle, of the watermill, of the potter's wheel, of the lathe, and of such things as windmills, windlasses, pulleys, derricks, and countless other machines, to all of which a wheel, or at any rate a wheeling motion, is essential. It requires but little reflection to make one perceive how far-reaching would be the results today were all knowledge of rotary devices suddenly lost by mankind. Yet ancient America was quite without that knowledge, for it is not too much to say that in all the Western Hemisphere not a wheel turned till Columbus arrived. The nearest approaches to wheels and wheeling movement are seen in the Alaskan region where some of the natives rolled the canoes into the sea on logs and in Mexico where fire was ignited by means of a stick rapidly revolved between the palms of the hands while its point rested upon another bit of wood. ${ }^{45}$ Nevertheless, the ancient peoples of America were by no means

${ }^{45}$ Wissler, 1917, pp. 37, 69, 127-133, 358.

Means, 1916. 


\section{I24 RACIAL FACTORS IN DEMOCRACY}

lacking in mechanical devices. Litters were certainly used in Mexico and in Peru (and very likely in Yucatan) by great personages. The travois and sledge were used widely in the more northern parts of the continent.

Nearly as important as the matter of rotatory mechanism is that of domestic animals. With the exception of the comparatively useless dog there were none such in ancient America. Only the Andeans with their feeble, wilful, semi-subjected llamas and the Eskimo with his specially developed sledge-dog had the slightest sign of an animal helpmate and burden bearer.

Again, in the matter of metals, the New World was behind the rest of the planet. Copper was fairly widely used; bronze (i.e. copper deliberately alloyed with tin) was pretty general in the Andes but markedly less so in Middle America. As a result of this, all the marvelous carvings in Mexico and Central America were made with stone implements of flint, obsidian, and similar materials. Iron, with one possible exception, ${ }^{46}$ was never used in ancient America.

Equally striking are the absence of milk and of the true arch from indigenous American cultures, to say nothing of an utter deficiency of nativeevolved stringed musical-instruments, means for artificial lighting (save among the Eskimo, who had lamps), and substances, whether vitreous or otherwise, for use as window-panes. Of the four great textile materials (cotton, wool, linen, and silk)

${ }^{46}$ Ambrosetti, Juan B.: Arqueología argentina; el bronce en la región calcbaqui. Buenos Aires, 1905. P. 305. 
only the two first named were used by American aborigines. These are some of the chief shortcomings of American cultures on their material side. Hardly less important is the intellectual loss occasioned by the very limited use of any system of writing. The Andeans, who had no writing, had an intellectual heritage much less rich than it would have been had they possessed some means of recording their thoughts. As it was they did have a rather rich verbal literature. 


\section{THE FUNDAMENTAL LAWS OF CULTURAL GROWTH}

A. The Nature of Culture

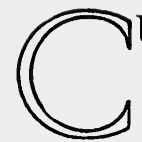

VULTURE, the complex of conditions created by man and his psychological reaction to those conditions, has been shown to vary from place to place and from age to age. Culture is continually undergoing modifications and improvements, sometimes it undergoes modifications and processes of deterioration. According to most thinkers on this subject in the past, culture progresses through an evolutionary series to its highest stages. In many parts of the world a society has begun to mount through such a series only to stop part way up, just as some of the branches of a tree do not reach so near to heaven as some others. All this is undeniably true, of course; it is even preponderantly true that any reasonably high and complicatedly complex culture can be proved to have passed through a series of forms arranged in an evolutionary series. Nevertheless, logical evolutionary development in cultures has not been a universal fact, as we shall presently see. It is by no means true that all cultures grow smoothly, evenly, unhurriedly from stage to stage or that all cultures in the same stage are alike; the infinite 
diversity of the human intellect is such as to preclude the possibility of such a delightfully simple and automatic way of cataloguing human cultural activities. $^{1}$

Yet obviously various stages and grades of cultures do exist, always have (since the dawn of cultural progress), and always will. It is equally manifest that any high culture comprises elements which are in truth the cream of its excellences at various stages in its upward career, elements which have survived because of their inherent virtues. Therefore it is true that "Civilization is the composite result of progress from the purely natural life of the animal to the purely artificial life of the most enlightened individuals and peoples." 2 In this book I have used the word "civilization" to describe the more intricate manifestations of culture. The differences between a culture and a civilization are not so much those of quality as of quantity. Not every culture is a civilization, for some of them lack the intricacy which would entitle them to be so called; but every civilization is a culture. As the contrast between civilization and culture is almost nil, so is the divergence between the highest civilized community and the lowliest savage society not very striking when one comes to regard it dispassionately. Although the material creations of the former are immeasurably more numerous and more bothersome - than those of the latter,

1 Boas, Franz: The Mind of Primitive Man. New York, 1916. Pp. 175-I 84 .

${ }^{2}$ Mason, Otis Tufton: Woman's Share in Primitive Culture. New York, 1894. P. 272. 
thereby creating a seemingly tremendous contrast (which is only superficial, after all), the spiritual inward nature of the civilization is apt to be only half a pace ahead of that of the culture. We need to develop in ourselves a wholesome humility. For all our material accomplishment, we are as capable of ignoble actions as any savage. The fact is that human progress has only just begun. We are in a stage now where no society and no culture can rightly scorn any other and where no opportunity to seek for good beyond our own immediate environment should be permitted to escape us.

\section{B. How Culture Grows}

The processes by which culture grows are in themselves a fascinating study. In general terms, the processes fall into two great groups: those of originating and those of borrowing. They shall be considered in that order.

The originating processes are those which we may regard as one of the causational factors in the unevennesses of cultural mutations. An invention may send a culture ahead a stage or two overnight. So lacking in apparent logical reasons for their occurrence are such inventions that they must be regarded as the product of the mind of some extraordinarily gifted individual, of the mind of a "genius." Such a "genius" among the anthropoid apes discovered that he could throw stones and so kill the prey he wished to devour. Such a "genius" seeing a rotten branch fall from a tree upon a sleeping bear and kill it thought of the club as a 
weapon. Such a "genius," on observing a tree set on fire by lightning, warmed himself in delight, for the first time, and ate the first cooked meal, composed of burned animals who had lived in the tree. Nor is this fortuitous combination of accident with "genius" limited to anthropoid apes and lowly arboreal men. Lamb's immortal whim anent roast pig is by no means lacking in elements of serious scientific suggestiveness. We are all familiar with the moral tale of James Watt and the tea-kettle, a modern example of the same combination of circumstances, as is also Benjamin Franklin flying his kite in the thunder-shower. It is not too much to say that every individual material element of our civilization had its origin in some interplay of accident with "genius."

Originating, however, is wholly incapable of being regarded as the sole factor in cultural development. Its complement, borrowing, is of at least equal importance.

At first glance borrowing seems to be a simple matter enough. Useful things are originated here and there, quickly become necessary to their inventors, are seen, envied and copied by the inventors' neighbors, and so pass on from clan to clan, from tribe to tribe, from land to land. A recent writer has pointed out how this occurred in the case of paper-making. ${ }^{3}$ The Chinese invented the art; the Arabs copied it; the people of Europe were taught the lesson at the knee of the Arab. Sometimes, usually on account of governmental shortsightedness, the first and hardest work on an inven-

3 Lowie, Robert H.: Culture and Etbnology, p. 9. New York, 1917. 


\section{I30 RACIAL FACTORS IN DEMOCRACY}

tion is done in one country and by one people only to be flouted, scorned, ignored in its birthplace and perfected in some other land and by strangers. Such was the situation in the case of the aeroplane. A little group of men, braving public derision and firm in their convictions, laid down in America the principles of gliding flight. These were Octave Chanute, S. P. Langley, James Means, A. Lawrence Rotch, Sir Hiram Maxim (then an American) and a few others who, during the last decade of the Nineteenth Century, created the first heavier-thanair machines for flying. ${ }^{4}$ But the representatives of the American people failed to encourage them. They failed also to encourage their direct inheritors, Wilbur and Orville Wright. As a result, the Wright Brothers (about 1908) took their invention to France, by which nation it was at once acclaimed. Ever since then France has been and is supreme in the manufacture of aeroplanes. Tragically similar is the story of the submarine which, since the days of Bushnell, Fulton, and Delaney in America; of Garrett in England; and of Goubet, Zédé, and Dupay de Lome in France has passed largely into other and less scrupulous hands.

Such events, then, constitute examples of what may be termed "pure borrowing." One people invents something; another people sees it, likes it, borrows it, and keeps it. Such a process is simple enough.

More elaborate, however, is the situation involved

4 See the collection of essays by and about these pioneers and their results in the Aeronautical Annual for $1895,1896,1897$, and in the Epitome of the Aeronautical Annual (I9ro), Edited by James Means. Boston. 
in other sorts of borrowing. Conquests of one ethnic group by another often, in fact always, result in borrowing on a tremendous scale. Usually the processes at work in this variety of borrowing operate slowly, not from day to day or from year to year, but from generation to generation. This truth explains why the Yue-Chih lived in Bactria about a century before reaching a high level of culture. It makes clear why the children of the entirely barbarous destroyers of the Roman Empire of the West were far more polished than their fathers. A crude but virile people being muscularly and martially superior to a highly civilized but old and decadent nation can overwhelm it by dint of sheer physical superiority. But the intellectual heritage of the vanquished is so majestic that presently it tames and tempers, then overpowers and absorbs the mentality of its invaders, just as a lion-tamer can dominate, by sheer force of personality and intellect, a beast which physically is his superior.

Akin to the military or horde conquest in its effects is the pacific but wholesale migration of peoples of one plane of culture into a society which is on a higher plane. The Incas of Peru, on conquering a low-cultured tribe, would move it bodily into the midst of a civilized community "where they would be surrounded on all sides by faithful vassals of the Ynca" ${ }^{5}$ and so would be acculturated upwardly. A parallel situation is found in our own midst. Droves of peasant immigrants from Europe have come among us in the last six or seven decades. Many of these, particularly those from the North-

- Garcilasso, 1869-71, II, p. 215. 


\section{RACIAL FACTORS IN DEMOCRACY}

east and from the Southeast of Europe, not only live according to standards vastly inferior to those of our own people but they also, on account of centuries of oppression and misery, are themselves personally thoroughly objectionable. The Russian Jews are a case in point. Yet no matter how much one may dislike their characteristics he has only to travel in Russia or to see "The Yellow Ticket" to understand why they are so and why their children, drunk with free air, are equally objectionable in another direction. Disgust is mitigated, however, by reflecting that, though the first generation is bad, the second generation turbulent and lawless, the third may be much better than either and the fourth as decent as any one. This, then, is an illustration of one phase of mass acculturation just as is the barbarian conquest of Rome.

Somewhat different, but not less far-reaching in its results, is that acculturation which arises from trade. Owing to geological, climatic, and other natural causes certain raw products necessary for our manufactures may be found in some districts but not in others. The activities that have for their purpose the bringing of these raw products to the places where they can be utilized constitute one side of trade; the other side is made up of those activities which result in the introduction of manufactured articles of one sort and another among people formerly without them. From the ethnological and cultural standpoints the latter category of activities is the more important. It usually implies the incidental existence of an elevating acculturation. When we see South Sea Islanders 
enjoying the breezes made by an electric fan, when we see an Eskimo listening with delight to the melody of the Blue Danube Waltz as rendered by a victrola, when we find a Quichua peasant-woman of upper Peru using a sewing machine, then we know that influences of this variety have been at work. All alike are indicative, even if only faintly so, of some degree of appreciation in the standards of living.

It should not be rashly assumed that trade-born acculturation concerns itself solely with the reactions of unequal cultures. This is not so. One has only to look about him with an inquiring eye to observe that our architecture is partly French, partly English and partly made up of a lot of extraneous elements infinite in number. Hitherto the sole contribution we North Americans have made to world-architecture is that exemplified by the skyscraper. Born of conditions peculiarly acute in lower Manhattan, this type of edifice is made the vehicle for architectural features derived as I have indicated. Yet it is truly North American product. Furthermore, because it meets requirements becoming more and more general, it is in turn borrowed, and we find sky-scrapers more or less pronouncedly a feature of contemporary architecture in London, Rome, Buenos Aires, and other cities. In all this we have a perfect example of the operation of the borrowing process among highly civilized people. Again, the same thing is seen in the ante-bellum prevalence of German toys and Swiss watches in America and of American shoes, typewriters, sewingmachines, and so on in Europe and all over the civilized or being-civilized world. Some nations 


\section{RACIAL FACTORS IN DEMOCRACY}

have an aptitude for making certain things which other nations cannot rival. So each one trades the things in whose manufacture it excels for the peculiarly excellent products of other lands.

In trade and in the cultural results which it entails geography has a tremendous influence. Up to a certain point of development man finds himself shut in and hemmed about by oceans, lakes, rivers, mountains, and deserts. As he climbs the ladder of cultural evolution, whether rung by rung or by long steps, he finds that these bournes become less and less restraining to his bursting energy. With a stone axe he fells a tree on which he rides astride upon the waters. By and bye he calls in the aid of fire, and presently he has made a dug-out and a paddle with which he voyages to shores where the people are as backward as he himself lately was. He teaches them his new-found art. Later, he learns how to make paths and roadways, and mountains lose their character of absolute barriers. The using of camels, horses, elephants, and railways all helps to make him override the deserts. Often, in fact, what was a wall becomes a highway. Rivers and river-valleys, because of the navigability of the former and the flatness and easiness of the latter are not only the seats of oldest empires but have been from time immemorial the highways along which have passed tradeinfluences. As man progresses he becomes more and more unconstrained by geographical circumstances. Highly civilized man can live and thrive in any situation not acutely menacing to the health. Even some diseases are now robbed of their terrors by serums. 
A final sort of acculturation should not be left unmentioned. That is the wholesale, deliberate and politically-engendered transculturation which has twice occurred in the world's history. In the period between $55^{2}$ and 630 A.D. the Japanese government perceived that Chinese civilization was vastly superior to their own. Indeed, it was at that time the highest anywhere in the world. Purposefully the rulers of Japan welcomed Buddhism and at the same time deliberately colored their society with the dye of Chinese civilization. Being essentially eclectic, they did not adopt certain features which seemed to them objectionable and harmful. The culture of Japan remained a simulacrum of that of China (with salutary omissions and with others not so salutary) until the middle years of the Nineteenth Century when, as a result of the Treaty of Simoda (2I Feb., I 855), Japan once more deliberately, but still eclectically, acculturated herself with foreign civilization, this time with Occidental, not Oriental, civilization. It is by no means true that either of these transculturations was the occasion for giving up features native to Japanese culture; at both periods the best of such features were retained, and they still exist, doubtless being destined to play an important part in the future.

\section{The Essentials of Cultural Growth}

From the immediately foregoing, as well as from the earlier chapters of the book, it is clear that certain circumstances must be postulated if a culture 


\section{RACIAL FACTORS IN DEMOCRACY}

is to remain vital. The first of these is the continuation of the processes of originating. The second is the maintenance of culture-contact and of the interchange of ideas.

Without continual and continuous contactual influences a culture may develop up to a certain point. It will, however, be marked by important lacks, and it will, eventually, reach a place where it will stagnate and finally retrograde. (The American civilizations are an example of this.) Had the Spaniards reached America about a century earlier than they did the history of this hemisphere would probably have been very different from what it was. Then, both in Middle America and in South America, the native cultures were at the height of their power. Obliteration would not have been their fate. Instead, a blending such as that effected by the British in India would have occurred, for the native civilizations would still have been sturdy enough to resist successfully the outsider and vigorous enough to profit by the stimulus applied by him.

The absolutely essential need of culture-contact on the part of a civilization cannot be better exemplified than by our own civilization. To quote Dr. Lowie's admirable statement of the case:

"Our immediate indebtedness to Rome and Greece has been drilled into us with such fulsomely exaggerated emphasis in our schooldays that the less said about it the better for a fair estimate of general culture history. That the Greeks were merely the continuators and inheritors of an earlier Oriental culture, must be considered an established 
fact. Our economic life, based as it is on the agricultural employment of certain cereals with the aid of certain domesticated animals, is derived from Asia; so is the technologically invaluable wheel. The domestication of the horse certainly originated in inner Asia; modern astronomy rests upon that of the Babylonians, Hindu, and Egyptians; the invention of glass is an Egyptian contribution; spectacles came from India; paper, to mention only one other significant element of our civilization, was borrowed from China." 6

To my mind, contact, which has been so important in the past, is destined to be infinitely more so in the future. Hitherto, with the exception of the Japanese, people have borrowed from one another more or less accidentally, haphazardly, unconsciously, and even unwillingly. We are now entering upon a period of the planet's history when such borrowing must become systematized and carefully planned for. The future of civilization hinges . directly upon the interchange of ideas. Up to date we of the west European civilization have been willing enough to impose our ideas and material accomplishments upon other peoples, and we have done so very successfully. That, however, does not constitute an interchange of ideas, for the traffic in ideas all moves one way. What we must do now is to try and learn something from others and to give over, at least for a time, the rôle of pedagogue to the universe. Our civilization is not

- Lowie, 1917, pp. 32-33.

Cf. also, Laufer, Berthold: Some Fundamental Ideas of Cbinese Culture. Journal of Race Development, V, pp. 160-174. 1914. 


\section{I38 RACIAL FACTORS IN DEMOCRACY}

perfect; it is merely mechanically excellent. Our great contribution to the world-civilization of the not distant future will be that of practicality, of technological dexterity in certain directions. While attaining to that distinction in mechanical matters we have lost boundlessly in things fully as important. In powers of soul, of spiritual and poetic selfexpression, in artistic ability, in political idealism, and in that intangible something that made life so sweet and pure in days gone by, when men and women made sacrifices without stopping to figure out what it would cost, in all this we have lost, lost, and lost. Yet those qualities still survive at their fullest in other societies. In our own they are by no means dead; the War is proving that; but they are not so strong, or rather so general, as they were. Then, too, in governmental matters, Europe and America are not noticeably more felicitously situated than they were when the Magna Carta was signed at Runnymede. If misery is less usual discontent is more so; if the public voice is louder in governmental matters the ill effects of bad ruling embitter more lives. We are so certain that our own forms of polity are the best that we rush on blindly with them, never pausing to see if perhaps there are not better ones. So it goes, throughout the long, long list of our cultural short-comings. When we have finished the final and definitive punishment of that nation which has carried to its logical termination that soul-less materialism toward which we ourselves were headed four years ago, we must, for our own sakes, as well as for that of the world at large, deliberately sit us down to learn 
whatever lessons our hitherto scorned or ignored fellow-cultures can teach us. We must, by our practical inventions, set about clearing up and utilizing the waste-places that abound in the world, but we must, if we can, find out the best, both material and intangible, that exists in each region opened up, and we must profit by it.

In causing waste lands to vanish we must also cause savagery and bestiality to vanish. By that I do not mean that we must continue the evil policy of exterminating all lowly peoples. That we must not do. Even the humblest tribes in the world have some native virtue, even if it is nothing more than that of possessing strong flesh, bone, and gristle. Then, also, we should remember that the lower levels of all middle-rank and upper-rank cultures are much the same, both in the standards of their lives and in their ways of thinking. The peasants of Europe are not profoundly dissimilar to those of South America, India, or China. We also should not forget that our own present superiority did not begin till about the Sixteenth Century and that up to then the civilization of Europe was on the same level of excellence as that of China; formerly it had been inferior to that of China. The American civilizations in the middle of the Fifteenth Century were hardly inferior to that of Europe in the middle of the Thirteenth. We are cultural parvenus, and we have the arrogance that marks the parvenu.

In short, all cultures have elements, phases, aspects in common. Side by side with these are the differences, some tangible, others supersensible, 
I40 RACIAL FACTORS IN DEMOCRACY

which mark the contrast between human minds in separate stages of development. The outcome of these similarities and divergences is a situation of the utmost intricacy and one requiring most careful adjustment in the relations of one culture to all its neighbors, so that no injustice may be done and so that no opportunity for betterment may be lost. 


\section{DEMOCRACY AND WORLD CIVILIZATION}

\section{A. Cultural Relationsbips and Racial Relationsbips}

$\prod \int \begin{aligned} & \text { AVING now rapidly reviewed the histories } \\ & \text { and qualities of most of the peoples on the } \\ & \text { earth we are in a position to judge with a }\end{aligned}$ spirit of fairness the racial and cultural situation which prevails in the world.

Hitherto race-relationships have been chiefly characterized by a feeling of apprehension, by injustice, scorn, and ignorance on all sides. We of the West, with our fair skins and our hypermechanical culture, with our social system and our altruistic religion (to which few of us are devoted and faithful in practice), have looked with contempt on races of other colors and of other creeds. No one thing is more indicative of that contempt than is our system of proselytizing. To be sure, missionaries are sent "to the heathen" with the kindliest intentions in the world; the missionaries themselves are often good, devoted, self-abnegating people fired by a lofty ambition to "better" the unfortunate folk among whom they go. I grant their unselfishness and the righteous intentions with all my heart, but nevertheless the truth remains that the sending out of missionaries is a practice born of 


\section{I42 RACIAL FACTORS IN DEMOCRACY}

race-contempt. We see in other lands institutions which differ from ours; we assume that ours are superior; straightway we send out people to knock down the native establishments and set up new ones, modeled upon our own, in their place. In other words, we contemn and, being kindly at heart, we seek to ameliorate the lot of all those unfortunate creatures who are not as we are.

Still more deplorable (because lacking in the friendliness that tempers our contempt) is the mistrust and jealousy of other races than our own which we have too often manifested. Of these sadly injurious and profoundly petty sentiments the treatment of Japan by the United States is an example. We allow ourselves to be misled by unworthy men in our own midst; we permit them to fill us with mendacious misconceptions which they constantly nourish by means of innuendoes and halftruths. Undoubtedly Japan is not a perfect country; indubitably nepotism, graft, and immorality are all too common there, even as they are in the United States. Without question the lower classes live in misery, squalor, and filth. But vainly does one seek to find, in all this, a great contrast between the Japanese and ourselves. In fact, before the occidentalization of Nippon, conditions of all kinds were better than they are now. 'The present-day situation, highly unpleasant though it is, must be attributed entirely to the too sudden transformation in the nation's culture, to a culture which, seventy years ago, was entirely unknown to them but which they have sought to assume at once. Of course evils have sprung up, evils which are certainly not 
the peculiar vices of the Japanese. ${ }^{1}$ Our attitude toward Japan today, when the Allied cause requires her intervention in Siberia and Russia, an intervention desired also by the English and the French, is one which shames us as much as it insults her. What man in business would hold back from a business venture on the ground that his partner might get as much or more than he out of it? That is precisely what our attitude is today, anent Japanese activity on the Asiatic mainland. (This passage was written in March, I9I8. Now, September, I918), the Japanese, the Chinese, and the Americans are fighting shoulder to shoulder, aiding the brave and staunch Czecho-Slovaks to free Russia from the perils of Teutonism and Bolshevikism, perils at once antithetical and identical.)

The fact of the matter is that all races and all cultures have some measure of good in their makeup. What we need to develop is an attitude decently charitable and a frame of mind wisely tolerant and receptive. It is customary to apply the word Chauvinism to national questions. The best

1 It has never been my good fortune to go to Japan. I have, however, talked with friends who have been there, both Occidentals and Orientals, on every possible occasion. My friends are various in point of profession, religion, and so on. I have also read, with what wisdom I could muster, these books, extremely diverse in spirit and purpose:

Gulick, Sidney L.: American Democracy and Asiatic Citizensbip. New York, 1918.

Flowers, Montaville: The Fapanese Conquest of American Opinion. New York, 1917.

Millis, H. A.: The Fapanese Problem in the United States. New York, 1918.

Sunderland, Jabez T.: Rising Fapan. New York, 1917.

Pooley, A. M.: Gapan at the Cross-Roads. New York, 1917. 


\section{I44 RACIAL FACTORS IN DEMOCRACY}

definition of the term is that of Sir Charles Waldstein: "Patriotism is the love of one's country and its people; Chauvinism is the hatred of other countries and other peoples." ${ }_{2}$ To the present day the feeling of certain Western nations, especially (let us confess it shamefacedly and with humility) of ourselves and of Germany, toward other cultures has been one of Chauvinism. We must mend this breach in our general attitude of fair-mindedness. The same breach on Germany's part will presently be mended for her by the two nations which, in their colonizing activities, have shown a minimum of Chauvinism.

Unfortunate circumstances are by no means limited to the relationships between nations with different races and cultures; they also have been characteristic of the relationships between different races and cultures within one set of political boundaries. England led the way in the anti-slavery movement; the South American countries followed and the United States came trailing after. Slavery abolished, we found ourselves with a tremendous race-problem on our hands. To the everlasting credit of the United States be it said that we have done more to solve that problem than any other American nation. The great work began in 1868 when Samuel Chapman Armstrong, guided by a noble ideal, founded Hampton Institute. In the early eighties Tuskegee was founded by Booker $\mathrm{T}$. Washington, a Hampton graduate. ${ }^{3}$ Ever since then these two schools, and a number of less famous

2 Waldstein, Sir Charles: Aristodemocracy. New York, 1917. P. 4I.

3 Peabody, Francis Greenwood: Education for Life. New York, 1918. 
ones, have been doing wonderful things to lift up a degraded race (full of admirable potentialities) to the level of the rest of our people. Their aim has not been so much that of teaching the Negro the prettinesses of life as it has been that of making him self-reliant, self-supporting, and self-respecting, of making him cease to regard himself as zoölogically the inferior of the white man. The Negro has unplumbed capabilities for good. These schools are bringing them to the front. Hampton's work along similar lines among the few Indians which our rapacity had left undestroyed was equally admirable until, in 1916, the Government caused the Indian Industrial School (Carlisle) to take over this part of Hampton's task, continuing, however, the full force of Hampton tradition. ${ }^{4}$

The race-problem in the United States is marked by the absence, on the part of both Negroes and Indians, of any specially strong heritage of cultural respect-worthiness useful for modern conditions. The Negroes, on account of the previous condition of servitude, were further hampered by the assumption, on the part of a class of whites, that they were low, bestial, and incapacitated for improving. It is a tragic fact that just enough of them were so to lend a color of verisimilitude to the assumption. Moreover, certain somatological facts undoubtedly indicate that the Negro is not so remote from the anthropoid apes as we are. Yet, because the union of a Negro and a white will give offspring that is fertile, we must look upon the difference as being exceedingly slight. When we examine the conditions

- Peabody, 1918, p. 167. 


\section{RACIAL FACTORS IN DEMOCRACY}

which mark the lives of the Negroes still in Africa we discover that they possess qualities and dexterities which we have long since suffocated in their transplanted kinsmen in America. As Boas says:

"A survey of African tribes exhibits to our view cultural achievements of no mean order. To those unfamiliar with the products of native African art and industry, a walk through one of the large museums of Europe would be a revelation.... The blacksmith, the wood-carver, the weaver, the potter, all these produce ware original in form, executed with great care, and exhibiting that love of labor and interest in the results of work which are apparently so often lacking among the Negroes in our American surroundings. No less instructive are the records of travelers, reporting the thrift of the native villages, of the extended trade of the country, and of its markets. The power of organization as illustrated in the government of native states is of no mean order, and when wielded by men of great personality has led to the foundation of extended empires. All the different kinds of activities that we consider valuable in the citizens of our country may be found in aboriginal Africa. Neither is the wisdom of the philosopher absent. A perusal of any collection of African proverbs that has been published will demonstrate the homely practical philosophy of the Negro, which is often proof of sound feeling and judgment." 5

- Boas, 1916, pp. 268-278. (Quotation from p. 270.)

Cf. also

Woodruff, Charles Edward: Expansion of Races. New York, 1909.

Weale, B. L. Putnam: The Confiti of Colour. New York, 1910. 
All this indicates very clearly that the Negro bas good capacities. It will be no more than two or three generations before the work of Hampton Institute and similar institutions puts him on an equality, moral, intellectual, and social, with the rest of us. In time the slavery-engendered antagonisms and prejudices will have vanished. Even now it is difficult to find a white person to whom the idea of marriage with a decent Indian is physically objectionable. That is because the Indian has never been enslaved - he has merely been well nigh exterminated.

Finally, the present war is doing very quietly and unobtrusively an immense amount of work toward bettering race-relationships in this country, as well as in others. Hardly a day goes by now but what one is able to read in the newspapers of some deed of gallantry and of noble daring done by the Negro or by the Indian troops of the United States. The Indian, of course, like those Orientals who are with our forces, is already on absolutely the same footing as the rest of our soldiers. The Negro's conduct is rapidly winning for him the same position. This is simply and solely because the Negro of today is a better man than his prototype of Civil War times. The merit which Hampton and other schools are creating in him is finding its due reward.

Bryce, James (Now Viscount Bryce): The Relations of the Advanced and Backward Races of Mankind. Oxford, 1902.

Alston, Leonard: The White Man's Work in Asia and Africa. London, 1907. Reuter, Edward Byron: The Mulatto in the United States. Boston, 1918. 


\section{I48 RACIAL FACTORS IN DEMOCRACY}

The race-problems which confront a large part of the world, notably India and Latin America, are concerned with the relations between the whites and the indigenes, all of the latter having a pronounced cultural heritage and firmly rooted social institutions of their own. To make the good portions of the native civilizations available for the future world-civilization is the underlying motive of the new interracial policy, called race-appreciation, which is slowly growing up in many lands, the home of its conscious expression being Mexico, but its workings being almost world-wide. In various countries, in India, New Zealand, Morocco, Madagascar, Burmah, and Sarawak, no less than in Mexico and the Andean countries, the white race of Europe has superimposed its political direction of affairs and at least fragments of its peculiar culture over peoples who, themselves, are of no contemptible capacity, as is amply demonstrated by their material and intellectual achievements during the time when they were still unmolested by foreign forces. From this situation has arisen, very widely, a cultural and racial conflict, or, as in the case of the British and French colonies, a cultural and racial contrast. England and France, with the noble-hearted foresightedness which characterizes them, have long done what all lands having a dual population and a dual culture must soon do, namely, they have sought out the best in the various native civilizations with which they have come into contact and they have harmoniously blended it with their own political programs. Mr. Alleyne Ireland, in speaking of Burmah, gives an example of this: 
"The most interesting feature of the administrative system of Burma is the use made by the Government of native headmen as tax collectors and petty magistrates. In I90I there were in the whole of Burma no less than 18,505 of these native officials. ${ }^{6}$ The regulation under which the headmen are employed simply establishes a modernized form of the village system which, in Burma as in India proper, has been the basis of the indigenous administration from time immemorial.

". . . The guiding principle of the village system is that, in addition to the personal responsibility under the law of each citizen for his own acts, there exists a collective responsibility of a village in regard to certain specified matters - in brief, the individual is the legal unit, the village the administrative unit recognized by the Government.

". . . Important as the village system is as an aid to the operation of the Criminal Law, its chief value lies in the administrative work performed through its agency. ..." 7

Mr. Ireland then goes on to show the various social and political benefits arising from this system. One is that the natives are given a wholesome and steadying sense of dignity and responsibility; another is that the Government holds the confidence of the people because they, as well as the English, participate in it.

Again, in speaking of Sarawak, Mr. Ireland says:

- The total population of Burmah, according to Mr. Ireland, is somewhat more than $9,000,000$.

7 Ireland, Alleyne: The Far Eastern Tropics. Boston, 1905. Pp. 85 et seq. 


\section{RACIAL FACTORS IN DEMOCRACY}

"The impression of the country which I carry away with me is that of a land full of contentment and prosperity, a land in which neither the native nor the white man has pushed his views of life to their logical conclusion, but where each has been willing to yield to the other something of his extreme conviction." 8

Here in America there is a crying need of this same policy of race-appreciation. I have already mentioned some of the North American aspects of the problem, it now remains for me to present some of the South American and Middle American aspects of it. In not all parts of Latin America and the adjacent islands is race-appreciation needed with equal urgency. Jamaica and Panama, to mention only two of a number of regions, have no need of it. Because of the extinction of the indigenes in those parts, or because of their lack of respect-worthy native culture, there is no reason why the white man's civilization should not have established itself (as it has done) in its totality. On the other hand, in vast regions (such as Mexico, the Andean countries and Colombia) there exists today a dual population, predominantly indigenous but controlled politically, and in large measure culturally, by people of Spanish stock. The control, because harshly unsympathetic to native institutions, has, during four centuries, proved itself injurious to both races. Race-conflict and culture-conflict of the sharpest kind have long been the retarding forces of vast power which have prevented the proper and normal development of those countries. Both the white stock and the native stock, as well as their 


\section{DEMOCRACY AND CIVILIZATION I5I}

respective cultures, are excellent. The great lack has been that of a careful, sympathetic, and intelligent blending. To bring about this blending is the aim of race-appreciation in America. To use the words of Don Manuel Gamio, the leading exponent of race-appreciation in America:

"The problem, then, is not that of avoiding a delusive aggressiveness inherent in ... indigenous groups, but rather it is that of directing their powerful energies, now widely dispersed, by attracting their individual members toward the other (European) group which they have always regarded as hostile, incorporating them, blending them with it for the purpose of making the national population coherent and homogeneous and of causing the language to become unified and the culture to tend toward one form. . . For a family to live in harmonious unity it is indispensable that all its members should enjoy in due proportion those economic advantages which their physical and intellectual condition, their age, and their temperament can provide them with. Similarly, for a group of families to form an harmonious whole ... it is necessary for them all to enjoy in just proportion their share of well-being, and this is only possible in a situation of economic equilibrium. . It is said that the form of governmént ... in Mexico since the Independence is that called democratic and representative, but in reality this is not so, for the indigenous classes have been forced to live under a governance derived, not from their needs, but from the very different ones of the European elements." 9

- Gamio, Manuel: Forjando Patria. Mexico, 1916. Pp. 15-16. 


\section{I52 RACIAL FACTORS IN DEMOCRACY}

In a word, race-appreciation is a doctrine or policy shot through with a spirit of kindliness and generosity; it is eager to find good and useful elements among all peoples wherever and whenever possible and, on finding them, to employ them for the benefit of mankind in general, not for that of one group in particular. In the words of Chapin:

"We must remember that none of the great civilizations of the world was the product of the genius of a single people." 10 These terms set forth the most salutary lesson that we of the white race of Europe can teach ourselves. It is a lesson that we North Americans, with our young self-confidence and sometimes rather exaggerated self-esteem, must especially learn, for use in our future trade and political activities, both at home and in the outside world. The white race of Europe neither has a monopoly of all the institutional, intellectual, and material excellence in the world, nor are all its institutional, intellectual, and material characteristics excellent. We must teach our special superiorities to all other peoples; and at the same time we must learn from our pupils the things which they can teach us.

To England belongs the credit of carrying out most thoroughly (albeit half unconsciously) the principles of race-appreciation. In every one of her colonies where the native peoples were found to possess institutions and material development at all respect-worthy or at all capable of being made respect-worthy, she has intrenched her power by means of local mechanisms rather than by violent

${ }^{10}$ Chapin, F. Stuart: Social Evolution. New York, 1913. P. 229. 


\section{DEMOCRACY AND CIVILIZATION I 53}

innovations. In this respect France is a close second; Spain and Germany are the worst offenders against the principles of race-appreciation; Holland and the United States fall midway between.

\section{B. The Nature of Democracy}

All that has been said before in these pages has been by way of preparation and foundation for the ideas I now mean to expound. In this period, which is preëminently one of transition and re-formation, every man or woman who has thought long, earnestly, and devotedly upon questions of public interest and of governmental principles and who has come to conclusions which seem to possess at least some measure of value, every such person owes it to society to present his ideas in published form so that, in the years to come, whatever may be serviceable in them shall be made accessible for those who shall have in charge the weaving of all such elements into the rich fabric of future worldcivilization. Our times are horrid (in the Latin sense); they are so because, like weeds in a garden of flowers, injustices and rancors choke and vitiate many of the beauties of which humanity is capable. But in the future, little by little, the weeds will be pulled up, and the garden will bloom with a splendor which never has yet been seen. Every thinker who can aid in the work of weeding, no matter how little, is in duty bound to do so.

In the midst of this well-nigh world-wide war against a nation which embodies one of the two antithetical perils which threaten to disrupt society, 


\section{I54 RACIAL FACTORS IN DEMOCRACY}

we hear at every turn and in every hour of the day the word "democracy." We all fight for it, we all long for it. But how very few have formulated in a pensive and dispassionate spirit the content and significance of that word. How few can tell in brief and clear-cut terms just what democracy is.

As I have gone about the world, in a good many lands and among all sorts and conditions of men, I have noticed that, in general, there are two sorts of democracy. One is that which does not yet (nor ever will) exist permanently. It is the sort that most men desirous of the establishment of democracy hunger for and dream about. The other is the sort which already exists, quietly and almost unnoticed, in our midst. To be more explicit, the first sort is the leveling and destructive variety of democracy; the second sort is that wherein classes exist, membership in them being determined by only one thing - personal merit - and wherein the underlying spirit is one of constructivism, not one of destructivism.

To make clear exactly what I mean I must speak in terms of specific examples. Very well, then. The obvious example of leveling democracy is that Bolshevikism which even now is encompassing the temporary destruction of Russia and which threatens the whole world. Bolshevikism is essentially a destructive, chaos-engendering force. It is a new phase of an old ailment, but to consider this phase alone is sufficient for us, since it is the phase which must be stamped out. The perils that raise their shaggy heads with unkempt madness-tangled hair between the now and the great future of our garden 


\section{DEMOCRACY AND GIVILIZATION I 55}

fill one with terror to contemplate. While the good, the brave, and the sane give all they possess and their very lives to put down one of the world menaces, the other stalks through the world with a venomed whisper there and a poisonous catch-word here. Russia lies prone, raped and dishonored, because of Bolshevikism; the disease is in England's vitals and in ours.

Let the danger be made clear (unwittingly) by one of our leading American Bolsheviks:

"The real strength of the Bolsheviki, however, lay in the fact that they represented the working classes of the world. The war is approaching a stage where the workers in all countries are rapidly gaining in power and influence. . . Here we have a new variant of the theory of democratic war. No longer does the issue hinge chiefly upon the relations between states but between social classes. . . This proletarian democracy is different, in aspiration at least, from any other that we know. . It is a Democracy which opposes not only Militarism, Autocracy, and Conquest but also such cherished institutions as Private Property and Privilege.

... There is a war beneath the war, a war of the poor and the exploited of all the world against all exploiters, big and little, respectable and disrespectable. The goal to which the Bolsheviki look is a society in which all shall have an equal opportunity to develop latent faculties, where every child born of woman is to have his place in the sun. . . ." 11

In these quotations one may see all the beauties of

"Weyl, Walter E.: The End of the War. New York, 1918. Pp. 182-184. 


\section{I56 RACIAL FACTORS IN DEMOCRACY}

Bolshevik argumentation. The writer first hails with delight the reducing of all humanity to one category - that of the proletariat - and then he states that everyone shall have an opportunity to develop latent faculties. He quite ignores the obvious fact that such development would never be permitted in his Bolshevik Paradise because it would result in the disruption of the noble category of the unable and in the rise of an aristocratic body made up of those whom a non-Bolshevik God had endowed with greater powers than those of their fellows. Next to destructiveness, inconsistency is the chief characteristic of Bolsheviks. It is in the highest degree interesting to set them going round and round in a circle, madly and vainly trying to unsnarl themselves from the mass of contradictions into which even a very short conversation will deeply plunge them, for, in addition to being irascible and acrimonious, they are usually stupid and illogical into the bargain.

Bolshevikism, then, is that social miasma which tends toward the denial of the manifest inequalities of human abilities. It aims to make the more excellent men and women keep on a level where the least excellent men and women can keep up with them without getting out of breath and dropping by the wayside in panting exhaustion. It is as if foot-races should be so managed that the fleetest runners should bind themselves not to come in ahead of the most lumbering. Its conception of democracy is that which portrays a state of rampant and triumphant mediocrity. To excel in anything would be to commit the heinous sin of standing out 
from the mass, of being, in fact, an aristocrat. Such a thing would never, never do. As a consequence all things tending to create such aristocrats - art, learning, religion, poetry, science, law, athletics, literature - would be abolished. Bolshevikism is moved, not by a noble desire to mend, restore, improve, and cherish whatever worthiness there may be; rather, its aim is that of tearing down everything that might win for some men a greater measure of admiration - or a smaller measure of disdain - than that meted out to the rest. Its life-blood is made of hate and bitterness, not of love and charity.

Few people realize, here in the United States, how really pressing and actual is the menace of Bolshevikism. We are wont to regard it as a disease exclusively the property of the working classes. Some of them, under-nourished, unenlightened, un-spiritual, and unhappy, have it truly enough. But it is found widely among the well-fed and the comparatively intelligent. Many of this type of Bolsheviks are those strange creatures who have spread abroad a fondness for "new poetry" and an unwholesome interest in erotic ethics (which should concern specialists only) and in parallel manifestations of degeneracy, both moral and mental. Many of them are merely those palavering faddists who, dwelling in a noisome atmosphere of sham Bohemianism (in steam-heated flats with Strindberg's plays and Sudermann's novels on the center-table), have as their purpose in life that of being advanced and of leading movements. It is often noticeable that the movements vary in character from week to week. 


\section{I58 RACIAL FACTORS IN DEMOCRACY}

They are one and all contemptible poseurs, these "intellectual" Bolsheviks, far more despicable than the labor-Bolsheviks, for they at least have the merit of being sincere, though cruel and stupid.

Such, briefly, is the wrong sort of democracy. Let me now speak of the pleasanter right sort.

True democracy does not consist of cramming all the infinite diversity of humanity into one category. On the contrary, its aim is that of devising a social and political system whereby each shade and variety of that infinite diversity shall be enabled to give expression to its ambitions and aspirations, thereby performing the functions for which it was created. The perfect democracy will be a state in which there will be classes absolutely rigid as to their functions for society but absolutely fluid as to the individuals who compose them. A man's or a woman's position in society will, in such a state, be determined by his or her peculiar aptitude and talents, not by hereditary position, nor by nepotism, nor by human authority, but solely by individual merit. There are two antithetical menaces against which society must fight. One, that involved in the outworn hereditary principle which continues in offices of trust unmeritorious and unable persons who are held in their positions by the arbitrary workings of the principle, is now being done away with forever. The other, the equally portentous and enervating spirit of leveling which denies to the good and the capable the power to exercise their virtues and abilities, is yet to be dispatched. Any institution which conduces toward the ending of these twin evils is a democratic institution. 
We may well be fervently thankful that already we have several such institutions in modern society. I will speak of three, the French Legion of Honour, the English Knightage, and the American Selective Service regulations.

Of these, the two first mentioned may be considered together, for they are much alike. The French Legion of Honour and the Knightage (i.e., that portion of it included in the Orders of the Bath, of St. Michael and St. George, of the Star of India, and especially the Order of Merit and the Distinguished Service Order) are the very acme of true democracy for the reason that admission to them and advancement from rank to rank within them depends simply and solely on personal deservingness. For this reason it is that in those bodies one may find men born in every possible social position who, however diverse in their origins, are welded into a true aristocracy, one of the mind, heart, and soul. Were it not for the hereditary element attaching to the British Peerage and Baronetage, these, too, would be examples of real democracy, for, in the majority of cases, the first holders of titles of nobility are men who deserve such honors on account of services rendered by them to society. Lifepeerages, indeed, are democratic. The day may not be far off when all peerages shall be for life only.

Almost ludicrously different from my first examples is my third. Yet the underlying principle position determined by merit only - is present in the Selective Service regulations of the United States as well as in the two other instances. 


\section{I60 RACIAL FACTORS IN DEMOCRACY}

Every able-bodied male citizen of this country between the ages of 18 and 45, unless already in the military service of the United States, or unless engaged in essential work, is immediately or ultimately liable to be inducted into the National Army. No favor, no influence, no wire-pulling can release him from liability to that call. Once inducted, or drafted, into service the recruit stands with his military career before him. If he has grit, pluck, brains, initiative, endurance, high-heartedness, devotion to duty, and all the other virile, soldierly virtues, he will gain promotion. The able man will inevitably reach the highest point in the forces to which his ability entitles him. If he lacks those qualities he will remain a private, which is, of course, no disgrace whatever, for even an humble man may be an honorable man. Meanwhile, the recruit, whatever his rank may be, will be learning the beauty and the soul-brightening qualities of discipline. He will learn that men are not all equal, that authority based on merit and ability must be respected. More than any one thing his obligation to salute his superiors, or rather their authority, will teach him that, for, though the private must salute the lieutenant or the colonel or the general, even the general must return the private's salute. The first salute pays the respects of the private to the general's authority; the second is a tribute of respect paid by the general to the private as a fellow man and as a co-worker in the fight. No human contact could be more beautiful - or more democratic.

This, then, is the nature of true democracy. How 
infinitely more magnanimous it is than Bolshevikism. That social ogre stamps out with hob-nailed boots the rare flower of individualism and personal superiority wherever it ventures to show itself. Its opposite, the democracy of merit, is extolled by a well-known Frenchman in these words:

" $I$, as a Frenchman and as a writer, if I stand for Democracy it is because it offers the safest and most acceptable and loyal basis for individualism. By individualism I don't mean egoism and selfish aims. The highest aim for individual life is selfsacrifice. Sacrifice to what you choose and love and want to serve.", 12

In order to appraise, if that is possible, the chances that the true democracy just now defined may have of being finally, definitely, and universally established on earth and in order to prepare to link up the relations between democracy and culture, let me make a few remarks about certain aspects of democracy as it is to-day.

The trend of political progress in recent generations has been to give the majority more and more power. He were a guileless and unsophisticated optimist indeed who could seriously contend that the wise outnumber the foolish or that the good and the generous are more numerous than the wicked and illiberal. Indeed, I never heard anyone, save a dear old clergyman in a remote country village where nearly every one is good, make any such contention. Most of us realize all too sadly that the majority is covetous of worldly well-being and

12 Lanux, Pierre de: New France and Young America. New York, 1917. Pp. $57-58$. 


\section{I62 RACIAL FACTORS IN DEMOCRACY}

material advantages; that only the minority is capable or desirous of self-abnegatingly devoting itself to an ideal. This being so, we must fain admit that the minority is nobler than the majority, and that the tendency (Bolshevik-like as it is) to pass over all the power into the hands of the majority is a menace to society.

To clarify this point I will analyze a certain aspect of the contemporary world. The tendency now is to concentrate all the power in the hands of one class of society. In Germany, because of the development there of the hereditary principle; that power is in the hands of the aristocracy of blood. In all the ancient world this was the most frequently met-with arrangement. In Russia, where the same situation till lately prevailed, the power now tends to be centered in the hands of the least stable and least practical or wise elements of society. In most of the countries of Europe and in the United States the power rests chiefly with our middle-class of well-to-do, materialistic, plodding, and unimaginative business men of various breeds. Owing to the nearly universal tendency toward majority rule, political power always centers in that class which is most numerous, except, of course, in hereditary autocracies like Germany, Austria, and old Russia. Majorities, being composed of the least intelligent, the least perceptive, the least analytical, and the least noble individuals, are more capable of being swayed by demagogues, rhetorical casuistry, and emotional appeal, and consequently they all presently fall under the rule of an oligarchy which presently becomes an autocracy. The cycle then 


\section{DEMOCRACY AND CIVILIZATION $\mathrm{I}_{3}$}

must be gone through with once more. ${ }^{13}$ This is precisely what has happened in Russia. That is what will occur in every country where Bolshevikism gains a foothold. It is likely to happen in any land where majority rule continues in force, without, that is to say, a radical and all-inclusive change in the present distribution of virtues. The bringing about of such an alteration in the quality of the majority must be the ultimate aim of all social reform. When it is completed, it will in effect indicate that selfish men, unscrupulous men, stupid men, and men lacking in the thousand and one intangible refinements of mind, person, and spirit which mark the nice-idealed man are no longer so numerous as the opposite sort of human being. Then will be the dawn of the bright to-morrow. Between us and then lie generations of upward struggling. We must kill Bolshevikism and hereditary principles. That done, we must submit ourselves to a government wherein the best, not the worst, shall rule, - to a minority government.

One of the first steps toward this minority rule, and through it to the right sort of majority rule, will be that of realizing that no class of society as at present constituted contains more or less excellence in proportion than any other. Men and women of the minority have been born in the homes of farmers, kings, bankers, day-laborers, and bishops. Each of the three great classes of contemporary society has its peculiar failures to achieve, as a whole, the level of excellence attained by the best people in

${ }^{13}$ Mallock, W. H.: The Limits of Pure Democracy. New York, 1918. Pp. 32-39. 


\section{I64 RACIAL FACTORS IN DEMOCRACY}

each. The so-called upper class is, or was before the War, slowly being poisoned by the unwholesome influences which seem to be inevitable concomitants of the senseless idleness and the joyless splendor of the newly rich. Yet there are newly rich, as well as "old families," who are neither senselessly idle nor joylessly splendid. These belong to the minority; being capable of an ideal, they should rule. The middle class is largely taken up with trying to imitate, amid much bitterness and many heartburnings, the worst aspects of the lives of the upper class. Their patronage of certain gaudy magazines that pander to the snobbish and their constant shopping after cheap imitations of the articles of luxury therein described indicate this. Yet there are thousands of this class who care far more about their mental and spiritual growth than they do about any material considerations whatsoever. These belong to the minority, and should rule. The lower class is money-mad in large part. Labor has the world by the throat and knows it. Most of labor cares nothing for ideals and for exalting idealism; it is chiefly concerned about having a crammed belly and a draught of beer. Likewise, it wishes to make those whom it considers more fortunate than itself become less fortunate than itself. Yet there are laborers who refuse to strike for more pay in the nation's hour of danger and who devote their savings to the nation's cause. These are of the minority which ought to govern.

Who, then, belongs to this minority of which I speak? I will name of its past and present members a handful. George Washington, Lincoln, Florence 


\section{DEMOCRACY AND CIVILIZATION 165}

Nightingale, Lloyd George, Charles Evans Hughes, Kossuth, Napoleon, Hugo, Wilberforce, Booker T. Washington, Darwin, Benjamin Franklin, Grover Cleveland, King George V, belonged or belong; two young dressmakers of whom I know who gave up their business to aid the Knights of Columbus by doing canteen work in France, the school-boy who gives up his chewing-gum and his attendance at the Saturday baseball game in order to give the money saved to the government, the banker who voluntarily gives most of his fortune to help on some public charity much needed, the news-vendor who, learning that a woman who had befriended him needed a transfusion of blood to save her life, offered himself to the doctor's knife, all these, because capable of following an ideal, belong to the minority which ought to be dominant. No doubt some of them backslide, no doubt some of them are not constantly magnanimous, but nevertheless, actions in the lives of all I have named and in the millions whom I have not named, show that the necessary spark is there. A sense of responsibility and of unhampered power is alone needed to make it a permanent flame.

\section{The Need of Applying Democratic Principles to Cultural Relationships}

The purpose of my argument up to this point has been the twofold one of showing that other cultures than our own possess their special excellences just as ours does, and that merit alone should determine a man's or a woman's position in life. I now 
propose to show what bearing this has on cultural relationships.

The general lack in both class-relationships and culture-relationships has been that of an all-pervasive spirit of tolerance, geniality, and good-humored forbearance. Class has clashed against class, nation against nation, culture against culture, race against race; everywhere there has been bitterness, suspicion, and strife; almost nowhere has there been an oil of clemency and kindliness to lubricate the surfaces of human contacts. This is an amazing truth, for individual men and women almost always have at least one of those qualities from the lack of which societies have suffered. One can seldom find a human being, be he savage or civilized, who has not one winning trait in his character or one power of being reached and softened by tender regard and by unceasing fairness of treatment. Yet societies, as differentiated from individuals, clatter when they touch and grate harshly against one another's susceptibilities.

As our age-long and evil habit of stating our ambitions in terms of materialistic wealth and of transmuting the stuff that dreams are made of into dollars and cents before we bring ourselves to the point of seeking to realize them has profoundly exacerbated social and class relationships, so also has our custom of esteeming unduly our own particular culture on account of its mechanical and technological superiority rendered us blind to the unquestionable excellences that ennoble other cultures. Most of us have lost sight of the fact that civilization, above all our own, is always a mosaic of elements, 


\section{DEMOCRACY AND CIVILIZATION 167}

assembled from widely separated sources to form a coherent whole. As this has been true in the past, so is it destined to become more and more fundamentally true and more profoundly necessary in the future. Scarcely any aspect of our modern west European culture exists which would not be improved by a judicious admixture of ingredients derived from other cultures and other races. Future civilization, to be permanent, beneficial, and logical, will make itself less diversified as between country and country and as between continent and continent, and it will, at the same time, become richer and more various in its composition, for elements now peculiar to one region and to one race will, if found worthy, become general throughout the world, being spread everywhere by the machines for traveling and for the dissemination of knowledge which are our special contribution.

I will give a few hypothetical cases to illustrate my conception of just how this principle of cultural selection might and should be made to operate for the good of the human race as a whole. 


\section{DEMOCRACY, RACE-APPRECIATION, AND FUTURE SOCIETY}

\section{A. Majority Rule and Minority Rule}

- NY person who looks at both past and present broadly and with a mind unheated by the fires of prejudice will confess to himself that the real reason for the very imperfect success of our democratic ideals in realizing themselves is that the will and the aspirations of the choice minority has been consistently obliterated by those of the heterodox majority, and that the world has been controlled by its worst, not by its best. ${ }^{1}$ For that reason the ideals, beautiful, noble, and truly Christian, of Liberty as enunciated by Washington, Jefferson, Franklin, Clay, and Lincoln, have, in the last forty or fifty years, degenerated into a chaos and an ignoble unenlightened materialism which exposes the nation almost equally to two deadly perils of social and individual freedom - syndicalism and demagogical despotism. - The fundamental reason for this very tragic degeneration is nothing more than this: in the days when the nation was born the majority of its people were Anglo-Saxon by descent and tem-

1 Lecky, William Edward Hartpole: Democracy and Liberty. New York, 2 vols., 1899. 
perament; the intellectual and material culture of the land was Anglo-Saxon. The majority of people was respect-worthy and self-respecting; they understood and honored the gracious amenities of life; they were not money-mad, nor were they selfish to any great extent; their religion was a burning faith which kept their souls clean; they loved good books, and the comparative simplicity of their daily life was unconducive to that pampering of the body and attrition of the mind and soul which is so general today. One has but to read contemporary literature, or to look about him in all walks of life to perceive how very plainly antithetical to this is the nature of the majority today. In the governmental, as well as in the purely social, aspects of the matter of degeneration in the majority, a sad, lamentable and dangerous change may be seen. To use the words of Ralph Adams Cram:

"Democratic government for the last twentyfive years has neither desired nor created leaders of an intellectual or moral capacity above that of the general mass of the voters, and when by chance they appear they are abandoned for a type that is not of the numerical average but below it, and the standard has been lowering itself steadily for a generation." 2

Everywhere, not only in the United States, but also in pre-war England, France, Italy, and in contemporary Spain and South America, one can see the same processes. The rotten state into which Society (using that word in the newspaper sense) had fallen in this country before the war finds its image in every European country. But here the

2 Cram, Ralph Adams: The Nemesis of Mediocrity. Boston, 1917. 


\section{I70 RACIAL FACTORS IN DEMOCRACY}

disease was caused by the introduction into the country of bad elements from outside, by the floods of low-charactered immigrants who poured into our land and corrupted our Anglo-Saxon blood with scores of mongrel strains. The growth of demimondainism among our good families is a direct outcome of this. In a certain eastern city of this country I have seen young men and women who had ancestors among that splendid group of men who signed our Declaration of Independence acting like drunkards and prostitutes; I have seen supposedly well-mannered girls find delight in "Mrs. Warren's Profession," "Salome," "Three Weeks," and similar literature; I have seen them deliberately seek low adventures in the slums; - in short, I have seen them behave just as the people in that remarkable anonymous book, "The Goldfish," act. Why do they do this? They do it because the tone of Society in pre-war days was sounded by the newcomers, whose origin was in heaven knows what gutter, and those newcomers, being essentially low themselves, lowered the Society which they rapidly dominated. Only here and there, in somewhat provincial cities (often those where the prevailing element was academic), did one, in pre-war days, find any vestiges of the old and simple beauty which delights in intellectual gold rather than in material gilding.

All that, of course, was before the war. Society now, to its credit be it said, is working hand in hand with the rest of humanity; indeed, Society may be stated to have become human. Let all real men and all true women in Society pray that the present improvement will continue. 
How does the question of minorities bear upon all this? Do those young men and women of good birth of whom I spoke belong to the desirable minority merely because their ancestors did? No! A thousand times, No! Do those parvenus who have corrupted them? Still less! Who, then, in Society, does belong to it? Those belong to it who, whether in the somewhat provincial cities of slightly academic tinge, or elsewhere, have kept themselves true to the inherited precepts of their forefathers. So also do those newly risen people who, instead of pulling down the moral tone of those among whom they have come, lift themselves up to the same level as the best in the older families. But, unhappily, both of these categories - the fine old and the fine new - are small, yet they are of the minority, the desirable minority.

The exact nature of this minority has already been broadly indicated, but if one is to make practical suggestions for social improvements and not content himself with impalpable theories, he must be more specific.

Other writers have dwelt, in my opinion, somewhat too lengthily upon intelligence as an attribute of the desirable minority. They have too often neglected the equally important desideratum of moral, intellectual, and spiritual decency. A man or a woman, worthily to fill a place in the minority which should rule, should be not merely intelligent, but likewise honest, upright, kindly, strong-willed, and self-denying. Intelligence alone is not necessarily a noble or a virtuous thing. To sum up, then, the nature of the desirable minority, one may say 


\section{I72 RACIAL FACTORS IN DEMOCRACY}

that it is composed of all men and women who are strong in mind and sound in the subtler virtues of the heart and soul.

The question of how far the rule by the minority should be carried and how it is to be instituted now confronts us. Is it possible to make the governments of the world depend solely on the will and opinions of any minority? Is it even desirable that such should be the case? To both of these queries I, for one, clearly and unhesitatingly answer "No!"

In the first place, the whole world now clearly admits that the consent of the governed is a prime requisite for any good government, whatever its form may be. For a system whose declared purpose is that of giving the world the best government it ever had it would be a fatal error and a heinous sin to start out by discarding this fundamentally humane and salutary principle. Minority rule, like every other human rule, will inevitably contain the germs of degeneration, and it must be subjected to checks which shall act as a wholesome antitoxic and which shall, on proper occasions, stay unseemly tendencies toward any form of imperfection. Therefore the consent of the governed must be had, and there must be governmental machinery for permitting that consent to make felt its support or its disapproval. At the same time, circumstances must be such that the general consent will not regain its present damaging omnipotence.

In the second place, pure minority rule is undesirable for the reason that it would quickly change the minority into a closed caste, and the hideous out-worn hereditary principle would come back to 
stay; selfishness, corruption, and irresponsibility would perform a danse macabre upon prostrate humanity, and then all would be to do over again from the very beginning. The necessary check upon this menace is found, however, in the expedient of introducing into the system a measure of majority rule. Presently I will show how this might be done without in any way injuring minority control so long as it remained as it should be, and in such a way that persons newly arrived at voting age, or newly arrived in any given place, could quickly prove their suitability or their nonsuitability for inclusion in the minority. The element of majority rule which I would see instituted would likewise automatically pave the way for that happy time when the majority - not the minority - shall be made up of the intelligent and the decent.

The psychological and mechanical difficulties of setting up minority rule are tremendous. How are the ignoble millions who today hold all the power in this and other lands to be induced to give it up? How are such vilely selfish creatures as the greedy profiteer, the striking munitions-laborer, the conscienceless politician and the unrighteous of other kinds to be overcome by the minority which will have earned the right to rule by its efforts in this war?

The task must be accomplished very subtly, very fairly, very slowly, very tactfully. But it must be accomplished, for only so can the world be saved from a fate but slightly less fearsome than that which Hohenzollern wished to inflict upon it. The German Empire is clearly the worst country 


\section{I74 RACIAL FACTORS IN DEMOCRACY}

in the whole world for the reason that it alone appears to be rotten through and through. There are, as yet, no visible signs that show it to contain a desirable minority. The menace of Hohenzollernism threatens to rule the world through the worst part of Germany's evil majority; the menace of majority rule as we have it in this country threatens to rule the world through its evil forces, wiping out those which are good.

\section{B. A Democratic Scheme of Government founded on the Principles of Race-Appreciation}

The root evil of our present political system is that righteous personalities have no chance to assert themselves and to try with the acid test of their questionings the sincerity of candidates for office. Rhetoric, demagogy, oligarchy, and mob-rule swayed by them we have, of course, in plenty, as Mallock has pointed out. ${ }^{3}$ Suppose, for example, a man who is thoroughly corrupt in politics decides to run for the governorship of a state. If he has what is known as "the gift of gab," that is, if he is picturesque, plausible, and magnetic in his address, he will quickly win the support of the majority, only the desirable minority remaining unhypnotized. At present there is absolutely no way for the minority to exert its beneficent personality over the majority. For one thing, the voting units are too large; for another, they are too impersonal. The candidate tells exactly what he wants to tell and not one word more, then he disappears from the ken of his hearers

$$
3 \text { Mallock, 1918. }
$$


and there is no way of questioning him or his motives. It might be argued that the mud-slinging which takes place at election-time performs this function, but in reality it does not, for it too is impersonal, and it is lacking in the personal poignancy which alone can make criticism effective.

Looking closely and anxiously at our own political institutions one finds no hint as to how to remedy these evils. The failure to discover such a remedy there discloses the limitations of our political institutions. Here enters in the importance of race-appreciation, for, though the representational system of government, as it exists in countries of West European culture, does not give the best possible government to most communities, races and cultures other than our own have evolved governments under which the mass of the people was far happier and far better administered than we have ever been. Such a case was the ancient government of Peru (described in Chapter IV). The first care of the state was to make sure, by means of a marvelous administrative mechanism, that every man, woman, and child in the land had plenty to eat, plenty to wear, plenty to do, and plenty of play. The people were happy, wholesome, and good. Today we mock and rail at such paternalism. In our frantic, headlong rush, and in our obsession with the idea of majority-rule, we never pause to ask ourselves if perhaps it would not be well to look into the past of our own and other races to see if there were not institutions and political systems which we might fittingly adopt and adapt to our needs. The aim of all 


\section{I76 RACIAL FACTORS IN DEMOCRACY}

social reform is supposedly that of giving the greatest possible measure of happiness to mankind. Are we really upon the right path to that goal?

Let me erect, in imagination, a state which might be created on race-appreciation's borrowing principle. As the great drawbacks of the Inca system were the presence of the hereditary principle and the total muteness of the popular voice, so will all other systems be found to have their failings; yet, by taking the best of each a wonderful system without the faults of any can be created. Let me, then, erect my state upon the principles of cultural selection.

All society (using that word in its sociological sense) would be divided into small units. Perhaps the word ban can best express the sort of unit I mean, for clan implies blood relationship, and the han, a Japanese institution, ${ }^{4}$ is strictly territorial. The size of the han would, naturally, depend on whether it lay in the city or in some sparsely populated district. Its membership should consist of about five hundred families, including, of course, a number of adult single persons. In order to qualify themselves for the vote all the members of the han would have to pass simple examinations in reading, writing, and general intelligence as to current problems. A han would have, probably, about one thousand men and women voters. Each han would be provided with a large assembly-hall where not only purely social meetings, such as dances and games, but also political meetings would take place.

4 Asakawa, K.: Some of the Contributions of Feudal Fapan to the New Fapan. Jour. Race Development, III, pp. 1-33. Igr 2. 
There, at stated times, the voters of the han would meet to elect the han-overseer. At these meetings the necessary element of majority-rule would play an important part, for the election would be determined by a majority of the votes cast. But, and here is the point of the matter, the voting would be of such a sort that the wholesome influence of the desirable minority which would inevitably be present would make itself felt. Suppose, for instance, that in a given han two candidates are up for election to the overseer-ship. One candidate is a man of upright character and great intelligence who has held office before, acquitting himself brilliantly therein. The other is a selfish man who has tried on sundry occasions to induce the city by corrupt means to buy his milk for the municipal maternity hospital, although it is well known that he waters the milk and that his cows are not carefully attended to. (Owing to minority control he has failed in this endeavor.) Each of these candidates, Henry Williams (the excellent man) and John Dimmock (the selfish dairy-man), stand up on the platform and address a small audience every member of which knows all about them from close personal knowledge. When Williams has told what he purposes to do in office if he wins the election the supporters of Dimmock arise in their places and, from the floor, before an embarrassing battery of appraising eyes, vainly seek to trick Williams into some statement about his past that shall damage him. Patiently he listens to all that they have to say and quietly he answers each of their questions. Being not only an intelligent man, but also a man of 


\section{I78 RACIAL FACTORS IN DEMOCRACY}

the highest probity, Mr. Williams is not at all disturbed by this ordeal. Presently it is over, and it is Mr. Dimmock's turn to set forth his views. Riled by the nonsuccess of his henchmen's efforts, Dimmock blusters and blunders in a way very damaging to his cause. When he has finished he, too, has to submit to open and public examination by all those voters who wish to question him. A woman rises and is recognized by the chairman (the retiring han-overseer). She walks close to where Dimmock stands and asks him if he does or does not properly sterilize his milk-cans before refilling them. He blusteringly says that he does. Then she asks him why he considers merely drying them off in a dusty back yard where all sorts of impurities might get at them the same as "properly sterilizing" them; finally she asks why he puts so much water in his milk, and tells how she and two friends (who both rise to confirm it) saw him doing so. Then a man rises and asks him if he did or did not promise the retiring overseer an automobile if he would use his influence to induce the city to buy Dimmock's milk. Dimmock has to confess that he did make that offer, and he has the graciousness to add that it was promptly and emphatically rejected. Then comes the actual polling. Each voter rises and says aloud before the crowd which candidate he or she votes for. Very few will have sufficient courage of their corruptions to brave the scornful glances which will rest on them if they vote for Dimmock, who has been shown to be sa unworthy. So Williams wins the election by about nine hundred and seventeen to about eighty-three. 
The importance of the personal equation in such voting as this would be tremendous, and it would be equally beneficial. So likewise would be the element of absolute publicity and openness. The fact that, in the last analysis, the consent of the governed could be ascertained by means of the han assemblies would likewise have a stabilizing and important humanizing effect. Suppose, for example, a situation arose in which the government proposed to do something radically wrong. By means of the han assemblies a fundamental popular disapproval would very soon manifest itself, and the government would wisely decide to mend its ways.

In a city of one million inhabitants there would be about five hundred hans, allowing about two thousand inhabitants to each han. The han-overseers, elected in the manner already described, would not only supervise all the administrative and legislative and judicial activities of the han, but would also meet together to elect, from among those who had previously served with honor in the overseership, the man or woman whose task it should be to perform similar functions in the city. The country districts might be conveniently divided up into communes or counties, care being taken to distribute the power equitably. The chief of a county would be selected in the same manner as the chief of a city. These officials would, therefore, constitute the second rank of the official world. They would likewise elect the state administrators from among those who had given satisfactory service in their own rank, and the state administrators would, 


\section{I8O RACIAL FACTORS IN DEMOCRACY}

in like manner, select the head of the nation. There would be no legislature (a frequent source of inefficiency and corruption), but the administrators of different ranks would have terms not more than two years in length and they would not be able to hold the same office for two consecutive terms. Thereby the growth of despotism would be effectually prevented. To aid the administrators in the enormous number of subsidiary governmental tasks there would be a large corps of expert assistants from whose number all non-elective governmental posts would have to be filled.

Like the administrative hierarchy, the experts would be divided into ranks. The lowest would consist of those who had passed comparatively simple examinations intended to test their ability to aid in the regulation of the hans. From this class the han-overseers would be obliged to select all their assistants. Above that rank would be another, entered by means of stiffer examinations, from which the city or county administrator would choose his helpers. And soon. The examinations would not be under the direct control of the government (though of course they would be subject to its supervision). They would be in the hands of the recognized centers of education and learning, the ordinary public schools having charge of the lower and less specialized ranks, and such bodies as universities, technical schools, learned societies, and special experimental institutions having charge of the higher and more specialized ranks.

Provision would be made so that no one who wished to go into this civil service could begin part 
way up the ladder. Each would have to begin at the bottom and tangibly prove his or her ability and suitableness for promotion to the ranks above. Naturally those who had greater natural aptitude than others, and who had painstakingly equipped themselves with specialized knowledge would go ahead faster than less well fitted persons.

To illustrate the dimensions this civil service might attain, I will mention a few of the sorts of expert assistants the administrator of a large city would have to select:

Police-specialists to superintend the keeping of order in the city; protection-experts to take charge of the fire-department; sanitary experts to guard the health of the community; architectural experts to ensure the beauty and orderly development of the city; dramatic and literary specialists to superintend the proper recreational activities of the people; transportation experts to manage the public conveyances; economic experts to look to the public finances; specialists in landscape gardening to keep the parks of the city beautiful. And many others. The head of each department would be appointed from the proper rank in the service by the city administrator, and he would in turn choose from lower ranks those who would help him. The same principles precisely would be applied to state and national affairs.

Progression from the lowest rank, either in the administrative service or in the auxiliary civil service would not only be orderly and rationally founded on experience, but it would also be dependent on just one thing - personal merit. The 
fact that the civil service examinations would not be in the direct control of the government would tend to keep up their standard, for it would mean that the men who actually managed them would be of a sort which could regard public questions in a desirably dispassionate and critical frame of mind. To attain a place on the board of civil service examinations a man or a woman would have to have served satisfactorily in the service itself, and would have to be elected by the faculty of some recognized seat of learning to represent it on the board.

The present system of taxation could be materially bettered if the principle of using specially trained persons for highly technical work were properly developed. To illustrate, suppose that all the railways, telegraphs, telephones, wireless, aëroplanes, steamships, and street-cars, and a certain percentage of such industries as mines, farms, express companies, lighting and heating plants, automobile manufacturing, and so on were placed, tax-free, under the management of government officials drawn from those who had qualified themselves for the work in civil service examinations. The profit from such government-owned industries as these would, if not contaminated by political bossism (as it is too apt to be today), be so great that the burden of taxation would be very materially lessened. Of course provision would have to be made so that individual initiative and enterprise would not be discouraged, but would rather be encouraged. Certain industries would have to be reserved permanently for private ownership. Otherwise all incentive for a man to work hard to improve his financial condition would 
be lacking. Then, too, the very rich should be relieved of most of their money. I use the word " relieved" advisedly, for I am sure that if all those who have now ten, fifty, and two hundred million dollars in their fortunes were reduced to the comparative penury of one or two million dollars they would quickly feel relief in the truest sense of the word. Because they would be forced to live more simply their digestions would improve, and their minds would rapidly regain something of that mellowness, pliancy, and intellectual avidity which our ancestors had before we became over-rich. The very wealthy are not happy people; instead of envying them, the rest of the world should profoundly commiserate with them as to their unfortunate situation. Nor has their life, for all its exterior luxury and costly sparkle, one whit of the gracious and endearing reality and spiritual significance that the life of the people in the first half of the Nineteenth Century had.

To endow the public with the proper mental poise and saneness of judgment, education would have to be drastically overhauled. Emphasis would be laid, of course, on the strictly practical and matterof-fact aspects of instruction (those being the ones in which West European culture is specially capable), but, unless we wish to see soul-less Teutonic mechanicalism triumph, even in defeat, no less importance must be given to such soul-building and mindenriching studies as literature, art, Latin, Greek, sculpture, acting, dancing, and so on. Most modern people scoff too readily at those things which made "the glory that was Greece and the grandeur that 


\section{I84 RACIAL FACTORS IN DEMOCRACY}

was Rome." The hunger for beauty which brought about the creation of the noblest monuments to human intelligence in the world has almost ceased. to exist; it has been largely supplanted by a hunger for less noble and less inspiring things.

The benefits which would result from such a system as that which I have outlined (a system which contains suggestions from ancient China, India, Peru, and Mexico, from Madagascar and Abyssinia, as well as from the past and present of Europe and America) would be these:

(I) Because of the personal influence and example of the best and most intelligent men and women in the hans, the dangers arising from majority rule would be nullified and yet its good qualities would be preserved. Likewise, forces which now tend to depress the moral standards of the majority would presently begin to get discouraged and would shortly cease to be operative; thereafter, no doubt, the moral quality of the majority would rise.

(2) The openness of the discussion between candidates and voters, and the openness of the voting itself would prevent all bossism and venality.

(3) The chief cause of the imperfection of contemporary governments, namely, the legislative bodies, would be swept away. Both the administrative mechanism and the judiciary would be controlled by persons eminently qualified by preparatory study and experience to do so.

(4) Civil service would at last achieve an importance commensurate with its potential strength for good. At the same time, by keeping it utterly 
non-political and by making everyone in it enter at the lowest rank, rising only when his fitness to do so was amply displayed, it would be given the necessary technical and intellectual excellence. Every person working for the State would be, in greater or less degree, a specialist in his particular task.

(5) Personal merit, and that alone, would enable a man or a woman to rise in rank.

(6) The crushing and bitterness-engendering taxation of the present day would be profoundly altered for the better.

\section{Other Possibilities latent in Race-Appreciation}

Such is the improvement which might be wrought in the important matter of government by an application of the principles of race-appreciation.

Like government, many other things might be benefited by the same principles. Religion is a case in point. As we have seen, Christianity is not the sole faith which is exalted by the presence of high ethical and spiritual qualities. A very pronounced religious revival is undeniably taking place today in the cantonments and trenches of the Allies. As undeniably it is a non-sectarian revival. It seeks pure, lofty, and ardent spirituality; it is a faith and an exaltation quite unencumbered by dogma and pragmatism, wholly free from the old rigidities of form and content. The holy flame now beginning to burn as yet touches only the soldiers, but presently, when they come home, all society will be vitalized by a new realization of beauties 
rare, deep, and inward, but quite separate from those fleshly and earthly joys by which we all have set far too much store. This great hunger and thirst after intellectual and spiritual nourishment will need a varied fare to satisfy it. The nonsectarian religion of the returning soldiery will not be content to confine its musings entirely to Christian fields if others can be found which yield flowers of prayer and religious experience as sweet or sweeter. Eclecticism and catholicity will mark the faith of the tomorrow. Christianity, like Buddhism, Confucianism, Brahmanism and all other high faiths, will furnish its full quota of beauty and nobility to the composite yet harmonious whole.

Similarly, in painting, architecture and music, and in the scores of sister arts which furnish the cherished and endearing humanities that true spirituality and real intellectuality crave, race-appreciation is capable of becoming a potent force for good and for true progress. Through it our architects may learn at last that Greece, Rome, and mediæval Gothicism do not contain the only sources from which æsthetic inspiration may be gained. Already there is, in the Occident, a slight tendency toward justly appreciating the arts of China and Japan. But let that tendency be intensified, and, above all, let it be extended. Let artists and architects browse amid the deserted corridors of Angkor and Boro-budur or amid the vine-shrouded cities of Guatemala and Yucatan; let them study with sympathy the arts of primitive peoples the world over; let them steep themselves in the myriad beauties which have been produced by other races 
than our own. This is a process which is already begun ${ }^{5}$; let it be carried on to a magnificent fulfillment. The ante-bellum madness of the cubists, vorticists, and whatnotists was merely the product of an utter sterility and stagnation of the æsthetic sense of Europe. From such deep degradation cultural selection is capable of raising us.

Nor is the gain wholly ours. We can, of course, vastly enrich our own civilization by blending with it the best elements of others. But the old cultures of Asia, South America, Africa, and Oceania, or the present-day survivals of them, will, in turn, profit profoundly by borrowing from us. No longer will we blindly suck them dry and leave them dead behind us. The conduct of the other races in this war has made it impossible forever for the white race of Europe to maltreat, ignore, and scorn them and their cultural capacity.

We are all on the same little planet. Let us show forbearance, kindliness and a spirit of wise emulation. Let us cease for all time to despise and to mock those who differ from ourselves. The people of the world must draw together into indissoluble union. We have a long journey to make, let all men and all races make it hand in hand.

5 As an example of the application of race-appreciation to artistic matters I will mention the work of Mr. Charles W. Mead, of the American Museum of Natural History (New York). Mr. Mead has for years been a close student of the marvelous designs to be found in ancient Peruvian pottery and textiles. Of late he has turned his attention to the adaptation of these designs to the requirements of modern manufactures of textiles. The success which has crowned his efforts, and the beauty of the work produced by his pupils is a tangible example of what the principle of race-appreciation can do, 


\section{THE ANTHROPOLOGICAL ASPECTS OF COLONIZATION}

\section{THE GENERAL HISTORY AND THE SIGNIFICANCE OF COLONIZATION}

DROM the earliest days of high civilization nations or peoples of a high plane of culture have sent out colonists to take up their abode among peoples of lower culture. In every case where this occurred the newcomers stimulated the aborigines and eventually, in most instances, caused them to take on a civilization which was a more or less perfect simulacrum of that which the colonists brought from their own home.

That, briefly stated, is the anthropological principle involved in the custom of sending out colonies. The purpose of this paper is that of pointing out very concisely how this law has operated in the past, and, more at length, of showing the highly important anthropological factors involved in modern and future colonization.

The ancient empires of the Tigris-Euphrates valley and of the Nile valley seem to have been active colonizers from an early date. As a general rule they annexed regions adjacent to their own territories, sometimes by diplomacy or through the agency of carefully planned royal marriages, but more often by war. Once a region was definitely 
annexed, it was firmly welded to the empire proper by the highly centralized supreme government of that empire. There was, apparently, no particularly noticeable degree of exploitation of the colonies by the central nation or its rulers. On the contrary, because the colonized territories were almost always close at hand, if not, indeed, actually contiguous with the empire itself, they generally became, within a generation, an integral part of the empire, scarcely distinguishable from the older territories of the realm in point of culture and social conditions. The truth of this statement may be observed again and again in the history of Sumer, Babylonia, and Egypt, an especially good illustration of it being Nubia which, to all intents and purposes, became merely a southward extension of Egypt proper. ${ }^{1}$

With the rise of seafaring a somewhat different sort of colony came into being. The Phœnician cities of Tyre, Sidon, Arvad, and so on sent colonies by sea to remote places which were not and never became contiguous with the home territories. It is true that the credit for establishing this sort of colony ought partly to be given to the Kingdom of

1 Breasted, James Henry: A History of Egypt. New York, 1912.

Wilkinson, Sir J. Gardner: The Ancient Egyptians. London, 3 vols., 1878 .

Bates, Oric: The Eastern Libyans. London, 1914.

Gosse, A. Bothwell: The Civilization of the Ancient Egyptians. New York, n.d.

Sykes, Sir Percy Molesworth: A History of Persia. London, 2 vols., 1915.

Winckler, Hugo: The History of Babylonia and Assyria. (Translated and edited by James Alexander Craig.) New York, 1907.

Rogers, Robert William: A History of Babylonia and Assyria. New York, 2 vols., 1915. 


\section{I9O RACIAL FACTORS IN DEMOCRACY}

Israel and to Chaldæa. During the long period between about $\mathrm{I} 200$ and about 600 в.c. the Phœnicians were establishing and maintaining colonies at Carthage, Aoza, Heraclea, Melita, Cadiz, on Corsica and Sardinia, and in the Tartessus region of southwestern Spain. The contrast between these Phœnician colonies and those of Egypt or those of the Tigris-Euphrates empires lies in the fact that the Phœnician colonies, maritime in their origins and far removed from their mother-country, were cultural colonies but not, permanently, political colonies. That is, groups of persons or of families, formed, for one reason or another, colonies which set out from Phœnicia to find new homes for themselves along the shores of the Mediterranean. They took with them all the skill, ability, religion, and general culture which distinguished the people of the old Phœnician cities, and they established those cultural attributes in their new homes, sometimes blending with them elements derived from the culture of the natives of the region in which they found themselves. Political connection with Phœnicia proper was merely nominal, and it was not always even that. Undoubtedly the colonists regarded Phœnicia with that same sentimental and intellectual attachment which Anglo-Saxon North Americans feel toward England, but of more definite bonds there were none, after the first generation or two in the new home of the colonists. ${ }^{2}$

2 Cooke, George Albert: Pbonicia (in Encyclopædia Britannica, IIth Ed.).

Lewis, Sir George Cornewall: Government of Dependencies. Ed. by Jacob Gould Schurman, New York, 1901. Pp. 64-65. 
The colonies sent out by the various city-states of Greece were of several characters, but in general they tended to approximate the nature of the Phœnician colonies. They were like them, too, in that a desire for commercial advantage was the chief motive, in many cases, for the foundation of a colony, and it was almost always the chief bond between the mother-state and the colony. Neither Phœnicia nor Greece was distinguished by a tendency toward centralization, and for that reason it is not surprising that the ties between mother-state and colony should have been so loose. On the other hand, in the highly centralized empires of Egypt and of the Tigris-Euphrates valley, there was every dynastic and political reason for making the adjacent regions an integral part of a growing, haughty, territorial empire.

While Rome was growing towards supreme power in the Italian peninsula, she colonized more or less the same way Egypt did. But Rome was particularly able to aggrandize her power in the face of remarkable difficulties. In her early days, both royal and early republican, that city was surrounded by many states and tribes equal or nearly equal to herself in culture and in strength. Indeed, it is likely that Rome herself had a bi-partite population, the Sabine patricians standing out in contrast to the non-Sabine plebes. She began her imperialistic career by overcoming one by one the Etruscan cities to the North of her, and other powers round about. Having once mastered a territory, Rome would skillfully consolidate it, and would then surround the consolidated area by a circle of de- 


\section{RACIAL FACTORS IN DEMOCRACY}

pendent allies and colonies. Sooner or later, each one of these revolted, which always gave Rome an admirable excuse for annexing and consolidating it. Then a new set of allies and colonies would be created. By the year 264 B.c. Rome, by using this process, had made herself supreme in Italy. In the later republican and in the imperial periods the same system (more or less modified, according to special conditions) was used for carrying on Roman expansion to its greatest extent. As Rome grew, especially under the empire, a tendency toward stricter and stricter centralization made itself apparent. The republic regarded the provinces merely as the estates of the Romans, but the empire tended to do away with distinctions between Italy and the rest of the empire, making all regions equally subservient to the imperial authority which operated through a highly centralized bureaucracy, the prefects and governors of outlying regions being directly responsible to the imperial government. Under the republic there were numerous hampering restrictions on trade and other intercourse, but under the empire this was not the case, and provincial men of weight might well expect to achieve high places in the imperial government or in the intellectual world of Rome. The fact that a number of the emperors were provincials is eloquent of this. ${ }^{3}$

${ }^{3}$ Mommsen, Theodor: Römiscbe Gescbicbte. Berlin, 4 vols., I856-85. The History of Rome. Ed. by William Purdie Dickson. New York, 5 vols., 1903 .

Pais, Ettore: Storia Critica di Roma. Rome, 1913.

Schwegler, A.: Römische Geschicbte. Tübingen, I853-58.

Ferrero, Guglielmo: Grandezza e Decadenza di Roma. Milan, 2 vols., 1902. 
In antiquity, then, there were two general categories of colonies: There were the colonies of the highly centralized empires of the Tigris-Euphrates valley, of Egypt, and of Rome. These colonies were contiguous with the mother-state, and they eventually became integral parts of the motherstate. Then there were the colonies of decentralized powers like the Phœnician cities and like the Greek city-states, colonies which had very slight, if any, political relations with the states which gave them birth.

The anthropological and cultural significance of both sorts of colonies in antiquity was tremendously important. It is, of course, obvious that such colonies, coming from advanced and highly cultured states, must have been exceedingly active in raising the general culture-level of the peoples among whom they established themselves. Less obvious, though hardly less important is it, that the culture of the various lowly communities thus placed in contact with high civilization must have reacted profoundly upon the culture of the colonizers. Imperial Rome undeniably spread Roman and Græco-Roman culture far and wide, into Spain, Britain, Dacia, Africa, Arabia, and other regions, but equally undeniably Roman society, and especially Roman religion and Roman philosophy, took on a large number of characteristics directly derived from the peoples among whom she colonized. For that reason

Seignobos, Charles: History of the Roman People. New York, 1902. Gibbon, Edward: The History of the Decline and Fall of the Roman Empire. London, 12 vols., $1783-90$.

Frank, Tenney: Roman Imperialism. New York, 1914. 
is it, that our civilization today, and especially that part of it which we have derived from Rome, is so highly synthetic in character. Not only that, but also Roman influences, acting through the agency of more or less sporadic maritime activities in the Arabian and Red Seas and in the Indian Ocean, made themselves, for a time, very prominent, if not really dominant, in certain parts of India. ${ }^{4}$

The influences here referred to were associated with what may be called a cultural or moral (in contradistinction to a political) colony. Of this sort of colony I shall speak at greater length presently. ${ }^{5}$

\section{COLONIZATION FROM THE TIME OF THE ROMAN EMPIRE DOWN TO I9OO}

Throughout the period of one thousand years or so between the decline of the Roman empire and the beginning of the Renaissance colonization, as far as Europe was concerned at least, was comparatively unimportant for the reason that the peoples of Europe were too actively engaged in passing through profound internal metamorphoses to possess the cultural vigor which the sending out of colonies demands. It is true that the Norman conquest of England in 1066 and the English con-

4 Smith, Vincent A.: The Early History of India. Oxford, 1908. A History of Fine Art in India. Oxford, I9II.

Barnett, Lionel D.: Antiquities of India. London, 1914.

Dutt, Romesh Chunder: History of India. London, 1906.

${ }_{5}^{5}$ Mookerji, Radhakmud: Indian Shipping. London, I9I2.

Coomaraswamy, Ananda K.: The Arts and Crafts of India and Ceylon. London, 1913. 


\section{THE ANTHROPOLOGICAL ASPECTS $\mathbf{1 9 5}$}

quest of a large part of France during the Fourteenth Century and Fifteenth Century both possess certain aspects that suggest colonization of the centralistic type. Again, the Moorish conquest of the southern half of Spain suggests the centralistic type of colonization also. Anthropologically speaking it was far-reaching in its effects, for it not only left a strong strain of Moorish blood in Spain, but it also deeply dyed Spanish culture, religion, and language. In spite of these exceptions, however, the period was, on the whole, comparatively unimportant from the point of view of colonization. ${ }^{6}$

Prince Henry of Portugal, surnamed "the Navigator," was the man to whom we must look up as the founder of modern colonial enterprise. All through his life (I394-I460) he devoted himself to expanding Portuguese power in western Africa and in the Atlantic archipelagoes off the African shore. Though he was a slave-trader, he was much more besides, and he it was who gave the first push which started the people of the Iberian peninsula on that career of discovery and colonization which made them, for a time, the leaders of Europe if not of the world. ${ }^{7}$

- Histoire Générale du IVème Siècle a Nos fours, Ed. by E. Lavisse and A. Rambaud. Paris, 12 vols., 1894 .

For the sake of brevity I have omitted here all discussion of the very important colonial activities of India, the Turks, the Mongols, the Chinese, the Aztecs, the Quechuas (Peruvian highlanders), and other nonEuropean folk.

7 Azurara, Gomes Eannes de: Cbronica do Descobrimento e Conquista de Guiné. Ed. by Vizconde de Santarem. Paris, 1841. Cbronicle of the Discovery and Conquest of Guinea. Ed. by Raymond Beazley and Edgar Prestage, Hakluyt Society, London, 2 vols., 1896-99.

Freire, Candido L.: Vida do Infante D. Henrique. Lisbon, 1858. 


\section{RACIAL FACTORS IN DEMOCRACY}

With the discovery of the New World by Christopher Columbus in 1492 the new age of discovery and colonization was definitely established. By the Bull of Demarcation, given by Pope Alexander VI in 1493 , the newly found continent and all its peoples were divided, for missionary and other purposes, between Portugal and Spain. By 1545 Spain and Portugal had preëmpted the southern two-thirds of the Western Hemisphere, France had made a beginning of her colonization in the St. Lawrence basin through the agency of Jacques Cartier, and England, in the persons of John Cabot and his sons, Lewis, Sebastian, and Sanctus, had begun to push her power out into the northern parts of the Atlantic Ocean. ${ }^{8}$

The colonies to which these exploring activities gave rise were of a type different from the two types which we identified in speaking of the colonies of remote antiquity, yet having points of resemblance to both of them. Like the Phœnician colonies, those which now sprang up under Spanish, Portuguese, English, French, and other auspices were maritime colonies remote from the motherland; like the Roman or Egyptian colonies, they were lashed to the central authority by all the bonds and restrictions that more or less benevolent stupidity

Major, R. H.: The Life of Henry of Portugal Surnamed the Navigator. London, 1868.

Ruge, Sophus: Prinz Heinrich der Seefabrer. Globus, Braunschweig, Germany, 1894.

Cambridge Modern History. New York, 14 vols., I909-12. (N.B. This work will hereafter by referred to in this article under the initials CMH.)

8 Payne, E. J.: in CMH, I, Caps. I and 2. 
could devise. A degree of centralization that might have served well enough for territories not far away from, or even contiguous with, the home territories was forced to do duty in the governing of colonies which were not merely thousands of miles away but which were also separated from the motherland by many weeks of traveling and by the fact that they possessed inhabitants and environmental conditions wholly unlike those of the colonists' home. ${ }^{9}$

In view of this situation it is not, therefore, surprising that by 1830 a very large majority of the maritime, but highly centralized, colonies of Spain, Portugal, France, England, and other European countries should have shaken off the yoke of foreign (i.e., motherland) domination. At the date mentioned, of course, it had long been evident that the colonial system as it then stood was imperfect. England had had trouble with her American colonies ever since about 1770. The beginnings of active unrest in Spanish America began with a series of rebellions ten years later. Contemporaneous with the revolutionary movements of this sort was the rise of a new sort of colonization.

The point I wish to make here is just this: in America every one of the colonizing powers sought,

9 Many valuable monographs on the subjects of general geography, anthropogeography and so on have appeared in special periodicals. Among the most valuable are: The Geograpbical Review (American Geographical Society, New York); The Journal of the Royal Geographical Society; and the Boletin de la Sociedad Geográfica de Madrid. Equally valuable, but generally more technical, are the journals of the various national geographical societies, notably: the Sociedad Geográfica de Lima; the Société de Géograpbie (Paris); and many others. 


\section{I98 RACIAL FACTORS IN DEMOCRACY}

in spite of the immense distances between the colonies and home, to set up a state which was not only an exact simulacrum of the home state, but which was, in effect, an integral part of the central domain of the power concerned. France and England encountered, in their American colonies, no native populations of high culture or of great stamina. For that reason the societies which they founded in America shortly became thoroughly European in character.

The new sort of colonization to which reference has just been made is that which may be seen in British India, in French Indo-China, in French Algeria, and in British Egypt. The modern colonization of those lands is distinguished by a combination of strongly centralized control by the European Power concerned with an equally strong and very wholesome tendency to preserve all that is good in the native peoples and the native institutions of the colony.

Such, very briefly stated, is the general significance of the history of colonization from the fall of the Roman Empire down to modern times.

III. THE GENERAL CHARACTER OF CERTAIN MODERN COLONIES

The limitations of space make it impossible to discuss here the colonizing methods of all the Powers. Instead, I shall present a brief study of certain British, French, Japanese, and North American colonizing activities, selecting those which are the most important from the anthropological point of view. 


\section{A. British India}

The supreme head, in England, of the Indian government is the Secretary of State for India. $\mathrm{He}$ is assisted by a Council composed of from ten to fourteen members appointed to serve for seven years. At least nine of the councilors must have had residential experience (whether official or nonofficial) in India for a period of at least ten years, that period having ended not more than five years prior to their appointment as councilors. The Secretary and the Council have control over all expenditures and over all affairs which call for dealings with the native States.

Supreme executive authority is vested in the Viceroy, who resides at Delhi, and who is appointed by the Crown for a term of five years. Like the Secretary of State for India, the Viceroy is assisted by a Council. It is appointed, like the Viceroy, for a term of five years, and it consists of seven ordinary and one extra-ordinary members who divide up between them the eleven ministerial portfolios or departments of the government. There is a Legislative Council, also, consisting of the Viceroy, thirty-six official and thirty-two nonofficial members, special provision being made for the inclusion of Mohammedans. The Legislative Council is elected by a special suffrage and has considerable law-making power. The majority of voters in all parts of the Indian Empire is made up of natives.

Under the Viceroy there are a number of subordinate executives of purely English origin. For them 
the titles of Governor, Lieutenant Governor, Chief Commissioner, etc., are used according to the rank of their post. In addition to these English administrators there is a vast number of native princes and chiefs each of whom rules over one of the seven hundred or so native States. These States are all under the direct and active control of their prince or chief who rules through the medium of native governmental institutions. The imperial power of the British Crown is represented at each native Court by a Resident. It is this officer's duty to see that the imperial rules relative to the limitation of the size of princely armies, and the non-interchange of ambassadors between native Princes and similar matters are not infringed. The principle of local self-government is deeply rooted in India, and the representative form of government, together with the suffrage, is gradually being spread everywhere.

The analogies between the structure of the Indian Empire and the federal republic of this country are obvious. ${ }^{10}$

\section{B. British Egypt}

Egypt is ruled, under British protection, by a Moslem Sultan. British authority is represented by a High Commissioner for Egypt, and he is aided by a Councilor and by a number of consular officers. The actual administration of Egypt is wholly in the hands of the Sultan and his native Ministers.

From 1883 to 1913 Egypt had several representative institutions, the chief ones being the Legislative

${ }^{10}$ Statesman's Yearbook, 1918, pp. I12-116. (Hereafter, SYB is the symbol for this authority.) 
Council, the General Assembly, and the various Provincial Councils. Unlike the Indian bodies of this description, they were merely consultative. In I9I3 a new Legislative Assembly was created. It consists of the Ministers, sixty-six elected members and seventeen members appointed by the government so that certain minority elements shall not be wholly unrepresented. The elections are indirect, the voters choosing electors-delegate who in turn, elect the legislators. Though the Assembly has a veto, it may be overridden, so that, in effect, the government is not much restricted by the Assembly. The various Provincial Councils have a great degree of local authority, and ample provision is made for the employment of suitable natives in minor administrative posts. ${ }^{11}$

\section{French Algeria}

This colony is highly centralized under the authority of a Governor-General appointed by the central French government. The tendency is to make Algeria in effect a southward extension of France itself. ${ }^{12}$

\section{Frencb Indo-Cbina}

The territory that is meant by this term consists of the colony of Cochin-China and the protectorates of Annam, Cambodia, Tonking, Laos, Kwan-ChauWang, and Battambang.

The Governor-General of Cochin-China is a Frenchman. He has supreme executive authority

11 SYB, pp. 240-242.

12 SYB, pp. 849-850. 
over all Indo-China, being assisted in the discharge of his duties by a Secretary-General and by a number of Residents-Superior. Native tribunals have been established throughout Indo-China, and they have appeal to superior courts consisting of French judges having Annamite or other native assistants. The superior courts sit at Saigon and at Hanoi.

The protectorate of Annam is under the control of its own King, who rules through a council of native Ministers and in accordance with French wishes. French authority is represented by a Resident and by a garrison of French troops. Annamite mandarin functionaries (under French control) administer all internal affairs. The protectorates of Cambodia, Tonking, and Laos are organized on similar lines, though only the first has its own King. Kwang-Chau-Wang, on the Chinese coast, is under the control of a Governor-General. The old Chinese communal social organization is carefully preserved by the French authorities. ${ }^{13}$

\section{E. Fapanese Korea (Chosen.) Fapanese Formosa}

Chosen resembles Algeria in that the tendency is to make it an integral part of the Japanese Empire, just as Algeria tends to become an integral part of the French Republic. Chosen is under the authority of a Governor-General appointed by the Imperial Japanese government. The rule is very strict, but benevolent.

The situation of Formosa (or Taiwan) is exactly similar. ${ }^{14}$

$$
\begin{aligned}
& 13 \text { SYB, pp. } 844-848 . \\
& 14 \text { SYB, p. 1056. }
\end{aligned}
$$




\section{F. American Hawaii}

The Governor of Hawaii is appointed by the President of the United States. The Legislature is patterned closely upon that of the United States, the Senate ( 15 members) and the House of Representatives (30 members) consisting of natives (or at least permanent residents) of the Islands and having powers similar to those enjoyed by the State legislatures in the United States itself. There is a tendency to give the natives as large a part in the administration and law-making as is possible. ${ }^{15}$

\section{G. American Pbilippines}

The Governor-General of the Philippines is appointed in the same manner as the GovernorGeneral of Hawaii. $\mathrm{He}$ is assisted by a cabinet of which all the members save the Secretary of Public Instruction are Filipinos. In the Senate and in the House of Representatives the influence of the natives is very strong. There is a great degree of local self-government throughout the Philippines. ${ }^{16}$

Having now outlined the history of colonization and the general character of some colonies which represent that category of dependencies where anthropological considerations are of special importance, we are in a position to consider the matter of anthropological method in its relation to colonizing activities. It should be said here, however, that certain colonies (like Canada and Australia) are, from the absence of racial questions

$$
\begin{aligned}
& \text { 15 SYB, pp. 6II-612. } \\
& \text { 16 SYB, pp. 617-618. }
\end{aligned}
$$




\section{RACIAL FACTORS IN DEMOCRACY}

which characterizes them, comparatively or even quite free from anthropological complications of a sort which involve two or more races and their respective cultures.

IV. THE ANTHROPOLOGICAL ASPECTS OF THE COLONIES NAMED

A. The Anthropological Aspects of British India

Generally speaking the environment of India is tropical. In the extreme North, and also in various regions of the South, there are mountain-ranges which modify the normal conditions to a greater or a lesser extent. The Ganges valley and the other valleys of North India, as well as the low-lying or medium-leveled portions of South India, have always been the main seats of high civilization. These valleys are excessively hot and unwholesome in their climatic conditions, but nevertheless they are fertile and of a character which permits the growth (and likewise the decay) of high cultures. The huge mountain-barrier of the Himalayas has two chief gateways, that in the Northwest (through which the primitive Aryans and subsequent invaders came) and the lesser one formed by the Brahmaputra valley (through which the TibetoBurman and some of the Chinese elements have entered India). By sea, of course, India is readily accessible from many directions.

The present-day population of India may most conveniently be classified on a basis of language. The statistics may be tabulated thus: 


\section{THE POPULATION OF INDIA TODAY}

(Arranged according to linguistic groups.)

Austro-Asiatic family of languages:

Mon-Khmer..................... 560,000

Munda........................ 3,850,000

Tibeto-Chinese family of languages:

Tibeto-Burman.................... 10,930,000

Siamese-Chinese.................. 2,040,000

Dravidian family of languages:

Telugu......................... 23,000,000

Others........................ 40,000,000

Indo-European family of languages:

Aryan.........................232,820,000

English....................... 123,000

N. B. These figures, based on material in SYB, are only APPROXIMATE.

As the reader will already have noted earlier in the book, the ancestors of these stocks entered India at widely different periods and under diverse cultural conditions. This being so, it is not surprising that diversity should seem, to many travelers, to be the outstanding characteristic of the Indian population of today. As a matter of fact, there is a very strong tendency toward unification approaching even to a sense of real national unity in India, for the Hindu religion binds together more than two hundred millions of the India population with intangible, but unbreakable, bonds transcending all ethnic variations. ${ }^{17}$

To what degree the British rule in India has preserved the very wonderful native institutions of the country is a question of the highest importance P. 59 .

${ }^{17}$ Caldecott, Alfred: English Colonization.... London, 1901.

Mookerji, Radhakumud: The Fundamental Unity of India. London, 1914. 


\section{RACIAL FACTORS IN DEMOCRACY}

from the point of view of anthropology and raceappreciation. From 1612 to 1746 was the so-called "factory period" during which England traded in India on an equality with other European Powers, exercising little or no political influence over the native states. At that time the Mogul Empire had not yet crumbled. From 1746 to 1816 England was struggling with France for the possession of the paramount power which was being wrested from the enfeebled grasp of the Mogul dynasty. Ever since 1816 England has held the supremacy for which she strove so long and so bravely. ${ }^{18}$ Native institutions, in the shape of rule by native princely houses over their hereditary dominions, are very generally preserved. Indeed, the relations between the supreme power of the British and of the governmental institutions which they have introduced into India and the various native rulers of the native States (each with its peculiar social and political arrangements) is no more stultifying than is that between the federal government and the state governments in this country or in Bismarckian Germany. ${ }^{19}$ The relationship is a partnership on a basis of strict quid pro quo. The splendidly democratic and efficient social organization of the masses of the native peoples has been carefully preserved, modified here and there of course to meet modern conditions. ${ }^{20}$

18 Roberts, P. E.: in CMH, VI, Cap. xv, Sect. 2.

Caldecott, pp. 60-66.

19 Lee-Warner, Sir William: The Protected Princes of India. London, 1894. Pp. 180-205.

${ }^{20}$ Baden-Powell, Baden H.: The Indian Village Community. London, 1899. 


\section{THE ANTHROPOLOGICAL ASPECTS 207}

England emphatically does not own India. India merely depends on England for that supreme governance the function of which is to modernize India and adapt her institutions to modern demands so that the latent greatness of that country may again make itself apparent. England has destroyed no liberties in holding India; rather, she has given India the inestimable benefits of the Pax Britannica, of trade and commerce and industry, of European material and intellectual cultural stimuli. In turn, English culture has been enriched and stimulated profoundly by ancient Indian elements (such as pedagogical methods, philosophy, literature and art). ${ }^{21}$

Into all these great accomplishments race-appreciation of the semi-unconscious variety has entered largely. The situation, however, is still far short of being perfect. There is much to be done, and in the doing of it the conscious application of the principles of race-appreciation must play a leading part.

These principles should especially be consulted with reference to the problem of whether or not India is to have ultimate independence. The present condition of the masses in India is obviously open to sharp adverse criticism. But that condition, like many other things, is perfectible. The modern situation of the Indian populace is described by one writer in these words:

${ }^{21}$ Caldecott, 1901, pp. 73-83.

Sarkar, Benoy Kumar: The Influence of India on Western Civilization in Modern Times. Journal of Race Development, IX, pp. 91-104. 1918. 


\section{RACIAL FACTORS IN DEMOCRACY}

"These swarming myriads, vegetating, and content to vegetate, under the dominion of noxious traditions and grotesque superstitions - by what magical influence are they or their children's children to be rendered capable of self-conscious and selfrespecting national life? By education? 'Yes, that is the sole resource. But in how many years or centuries can education undo the work of enervating, soul-sapping milleniums?" 22

In this connection it is well to note that British dominance in India is by no means universally approved in India. On the contrary, there is a good deal of rather vigorous opposition to it, proceeding chiefly from two categories; i.e., rulers who have been, for one cause or another, "eliminated" by the Imperial government, and those partially occidentalized Indians who, by reason of their receiving a part of their education in England or Europe, feel out of tune with their surroundings at home and resent the contrast between their social position there and that which they quite rightly held in England. It should be observed, however, that it is from this very class of discontented "intellectuals" that England and the Indian government intend to build up a civil service and a magistracy composed predominantly of natives. ${ }^{23}$ To a dispassionate American observer the contrast referred to between the respect (not to say adulation) which a well-placed or royal young Hindu receives while in England at one of the universities and the

22 Archer, William: India and the Future. London, 1917. P. 26.

${ }^{23}$ Caldecott, 1901, pp. 70-73. Nor is the "theosophist" group, headed by Mrs. Annie Besant wholly to be forgotten. 
cold-shouldering and constant snubs which he receives at home from the Anglo-Indian society about him seems nearly as inconsistent and unjust as the discrepancy between our high-flown sentimentality about the Negro and our actual treatment of him must seem to a dispassionate Englishman. Unquestionably there is much, very much, fine human material with which to work in India. This fact has been emphasized by Mr. Archer and, coming from one who is anything but dazzled by India's past, it is of all the more weight. $\mathrm{He}$ says:

"Outside [of the hotel in Kandy, Ceylon], in the streets, I had seen Othello, I had seen Shylock, I had seen Sohrab and Rustum, I had seen a hundred stately and impressive figures. I had even seen two or three men who might have sat to a realistic painter as models for Christ - not, of course, the bland and lymphatic Saviour of pictorial convention, but the olive-browed, coal-eyed Enthusiast of historic probability. Surely it was a strange topsyturvydom that reckoned the races which had produced these figures essentially inferior to the trivial mob around me [in the hotel lobby]devoid of dignity, devoid of originality, devoid of earnestness, all cut to one dull pattern, all living up to the ideals of the vulgarest sporting papers, the only literature to which they appeared to be addicted." ${ }^{24}$

Thus vividly does Mr. Archer call attention to a fact that draws the thoughts of all thinking travelers, not only in India, but in scores of other regions.

24 Archer, 1917, pp. 28-29. 


\section{RACIAL FACTORS IN DEMOCRACY}

That is the fact that, whenever placed beside some other race of high cultural standing, the present-day Anglo-Saxon and Teutonic stocks, taken as a mass quantity, appear revoltingly dull, trivial, and silly. We have, as a whole, no sense of personal dignity. We do not hesitate to waste our brains and our time in matters of the most utter worthlessness. Our manners in our intercourse with our fellow-men more nearly approach those of the Yahoos than do those of any other civilized people. Only among the Latins and the Slavs does one find, in the white race, a prevalence of considerate courtesy and well-mannered reticence. To learn the sour truthfulness of this, go to a theater or a department store in America, Germany, England, or Sweden, and then get into a similarly representative crowd in Japan, China, India, Italy, France, or South America.

Though Mr. Archer frankly acknowledges the existence of less desirable elements in the Indian population, he shows that there is an amplitude of good clay to work with. It is just here that anthropology and race-appreciation should enter in. By an exhaustive and intensive study of the cultural and psychological past of the peoples of India, the good that lies in them can be brought out and the bad can be nullified. If real knowledge of the psychological make-up of the people is gained, teachers will be able to ascertain just what pedagogical methods are best suited to the mentality of their pupils. Indeed, it is not at all unlikely that the native methods of instruction will be found the best, especially if they are perfected in the light of 
modern occidental experience. Again, an examination of the early Vedic religion of India and of the other early and pure faiths of that land will reveal the best way in which to strip away the dross of superstition and revolting obscenities which has encrusted the old cults, and it will give the people a creed at once exalting and suitable. Again, and finally, eugenics, properly carried out on sound anthropological lines, will undoubtedly prove to be a powerful reviving force if it is but given a fair chance. In all this, the vast importance of raceappreciation and anthropology is patent.

\section{B. The Antbropological Aspects of British Egypt}

Egypt, a sub-tropical country whose fertile and habitable area lies mainly close to and along the River Nile, all the rest being desert with occasional oases, has a population made up as follows:

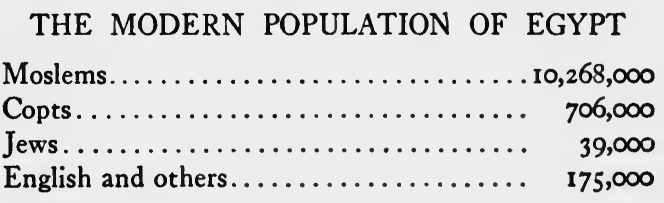

Although long ago Egypt had a civilization at least the equal of India's, she has, of recent centuries, been considerably inferior to India from the cultural point of view. Nevertheless, much of value survives from ancient institutions, as well as from more recent ones, and it is for race-appreciation and anthropology to blend all the elements, both cultural and ethnic, into a cohesive and harmonious 
whole. In fact, their function here will closely resemble their function in India, though the material will differ considerably. ${ }^{25}$

\section{The Antbropological Aspects of French Algeria}

Geographically and environmentally Algeria falls into three zones each of which extends from East to West. The northernmost zone is that called the Tell (Arabic for hill). It consists of shore country bordered on the North by the Mediterranean and on the South by the Little Atlas Mountains. These last are deeply and frequently indented by fertile valleys which are the seats of thriving communities. The climate is very salubrious. Agriculture, mainly cereals, has long been practiced. Next to the Tell, and lying between the southern slopes of the Little Atlas and the northern slopes of the Great Atlas is a broad plateau called the Shat, the altitude being roughly three thousand feet. It is a region of broad plains interspersed with salt-lakes and swamps. Save in the neighborhood of these, it is a healthy region. The Great Atlas forms the third zone. The altitude is between six thousand five hundred feet and seven thousand five hundred for the most part. Here, as in the Shat, swamps are numerous. Generally speaking, rainfall is plentiful in Algeria, and most of the country is either already under cultivation or capable of becoming so, under man's care.

Algeria is characterized by the presence of one of the most interesting populations in the. world. The combination of ethnic elements is very striking,

25 Cromer, The Earl of: Modern Egypt. New York, 2 vols., 1908. 
and it has already been touched upon from the historical point of view (in Chapter III). The present-day population may be summarized thus:

THE POPULATION OF FRENCH ALGERIA 26

Indigenes.............................

Berbers....... $75 \%$ of above figure

Arabs..........15\%

Negroes........ 5\%

Jews.......... $3 \%$

Others........ 2\%

French.............................. 234,000

Other Europeans. . . . . . . .

The French rightly regard the more than two million Berbers as the best ethnic stock in Algeria. Somewhat more than half of them habitually speak Arabic rather than Berber, and they are termed Berbères arabesants. Pure Berber is found spoken only among the Touareg tribes, but the French are doing their best to put a stop to the Arabization of the Berber stock and its language, for the Berbers are, when uncontaminated, honorable, industrious, and cultured. They live in stone villages (or adobe

${ }^{28}$ These figures are derived from

Bordier, A.: La Colonisation Scientifique. Paris, 1894. Pp. 172-175.

They are, of course, out of date now, but they serve to show the proportions of the ethnic elements. It should be noted that the Berbers are the descendants of those people among whom the Phonicians colonized and whom they called Libyans. The Libyans of times contemporaneous with the early Egyptian dynasties were made up of two strains: a stock indigenous to Africa and probably identical with the Mediterranean race, and a very blond stock from northern Europe.

See also Bates, 1914, p. 4 I, and:

Faidherbe, L. L. C.: Instructions sur l'Antbropologie de l'Algérie. Bulletin de la Société d'Anthropologie de Paris. 2nd. Ser. VIII, p. 603 ff. 1873 .

Sergi, Guglielmo: The Mediterranean Race. London, I90I. 


\section{RACIAL FACTORS IN DEMOCRACY}

ones). Their political organization consists of the decbera (commune) and the kebaila (confederation of communes). All the citizens, rich and poor alike, meet to vote in the djemâa or assembly. They are probably nearly the most democratic folk in the world today. The French realize that the Arab elements, by reason of their fanaticism and low morals, are a source of danger. They know that they are decadent and evanescent and that, as there is no reason to hope that they can be restored to the high place they once held, there is no particular reason to regret their imminent disappearance. ${ }^{27}$

The French are carrying out the best principles of race-appreciation in Algeria. They are doing everything in their power to increase the best elements in the population, and they are consistently encouraging the native social institutions. Their aim is expressed by M. Bordier thus:

"Si le peuple berbère disparait, la civilization européenne en général et la France en particulier auront a se reprocher de n'avoir pas su mettre en valeur un des éléments les plus vivaces de la race blanche.” ${ }^{28}$

\section{The Antbropological Aspects of French Indo- China}

The environmental conditions prevalent in French Indo-China are tropical. The ancient civilizations of the region have mainly had their seat along the

27 Bordier, I884, pp. 175-I8I.

Dubois, Marcel: Systèmes Coloniaux. Paris, 1895 .

Coen, Gustavo: La 2uestione Coloniale ed i Popoli di Razza Latina. Leghorn, I90I.

${ }^{28}$ Bordier, I884, p. $18 \mathrm{I}$. 
sea-coasts or in the broad river-valleys like those of the Menam and the Mekong. The region included in the political division described as French IndoChina is linked on the North with the Asiatic mainland proper and on the South and Southwest with the Sumatra and Java and the westernmost confines of Oceania. Undoubtedly it was a region passed through by many of the migrating stocks which gave rise to the present-day Oceanic population. Today the descendants of some of these early and primitive peoples may be seen in the hill-folk who dwell up in the hills in the less desirable portions of the country.

The present native population consists chiefly of a low stratum of negrito folk and of a variety of peoples (Annamites, Cambodians, Mois, Chams, Chinese, Malays, etc.) of varying sorts of culture. They seem to be mainly of northern origin, having filtered in from time to time. (See Chapter III.) The population may be tabulated thus:

\section{THE POPULATION OF FRENCH INDO-CHINA 29}

Cochin-China:

Indigenes.....................3,039,000

Europeans................... $11,0 \infty$

Annam:

Indigenes.................... $5,200,000$

Europeans.................. 2,100

Cambodia:

Indigenes....................1,634,000

Europeans................... $\quad \mathbf{I , 1 0 0}$

29 These approximate and unsatisfactory statistics are based upon material in SYB. They refer to the year 1914. I have sought in vain for more detailed material. 


\section{RACIAL FACTORS IN DEMOCRACY}

Tonking:

Indigenes....................6,120,000

Europeans.................. 6,100

Laos:

Indigenes................... $\mathbf{6}_{4} \mathbf{1}, 000$

Europeans.

Kwang-Chau-Wan:

Indigenes................... I68,000

Europeans.....................

The reader has already seen something of the history of the old native civilizations of this part of the world. Unlike the powerful states of India, those of Cambodia, Annam, and so on had lost much of their one-time cultural vigor by the time European influence began to make itself strongly felt. Nevertheless, the French, with characteristic sagacity, have observed that the native peoples have very good qualities, and they have set themselves the task of bringing out every one of them, proceeding always in accordance with the principles of race-appreciation. ${ }^{30}$ Wherever it has been found possible to do so, local autonomy and local native institutions have either been maintained in totality or they have been modified to meet modern requirements. ${ }^{31}$ Nevertheless, despite the good work that

${ }^{30}$ Means, Philip Ainsworth: Race Appreciation and Democracy. Journal of Race Development, IX, 1918.

${ }^{31}$ Bordier, 1884, pp. 384-400.

Chailley-Bert, Joseph: La Colonisation de l'Indo-Cbine. Paris, 1892.

Reinsch, Paul: Colonial Government. New York, 1902.

'Cerisier, Charles: La France et ses Colonies. Paris, 1886.

Russier, H., and Brenier H.: L'Indo-Cbine Frangaise. Paris, I910.

Lanessan, J.-L. de: Principes de la Colonisation. Paris, 1897.

Ireland, Alleyne: Tropical Colonization. New York, I899. Pp. $37-83$. 
has already been done, an immense amount still remains to be accomplished. In the task of welding all the rather diverse ethnic and cultural elements of Indo-China into a national solidarity both anthropology in general and race-appreciation in particular will have to contribute a large-sized quota of labor, and of informative data.

\section{E. The Antbropological Aspects of Japanese Korea}

\section{(Chosen)}

Korea, or Chosen, is a cold country with forested mountains and a rich soil which, for many centuries, has been made to yield a wide variety of edible and commercially valuable crops.

The population (1915) may be tabulated thus:

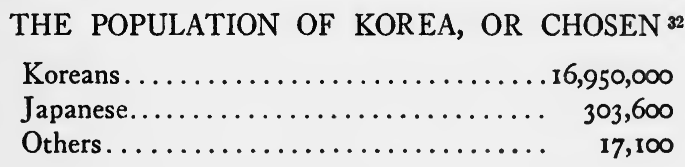

The theoretical aims of the Japanese government in Chosen (Korea) are stated as follows by the Government-General of Chosen:

"It seems that no great obstacle lies in the way of the two nations (Chosen and Japan) being assimilated and so becoming one. But in contrast to Japan, which, thanks to the wise and beneficent reigns of her successive Emperors, has steadily progressed towards civilization, Chosen lagged behind the times and fell into a state of weakness and

${ }^{32}$ Ladd, George Trumbull: The Development of Korea in Most Recent Times. Journal of Race Development, VIII, pp. 431-438. 1918. 


\section{RACIAL FACTORS IN DEMOCRACY}

decadence. Under the circumstances, though Japan and Korea have now become incorporated into one nation, there naturally exists a relationship in which one is the leader and guide and the other, the follower and pupil. In order that they may become thoroughly assimilated, the former must guide and assist the latter, while the latter must endeavour to work hard for self-improvement. The Government-General . . . intends to leave nothing undone that can avail to guide, teach and develop the Korean people. . . . It may be said, by the way, that prior to annexation there were in Chosen not a few Japanese who held themselves very haughtily towards the Koreans and treated them with scant respect. I, the Governor-General, thought that if such an attitude on the part of the Japanese towards the Koreans were left unremedied, the latter would harbour ill-feeling against the former and it would prove a great obstacle in the way of bringing about intimate relations between them. Accordingly I frequently gave instructions to the Japanese residents in Chosen to the effect that, as the Korean people were now subjects of the Emperor and their fellow-nationals, they should show sympathy towards them, treat them with kindness and live in harmony with them, helping each other. It is gratifying to note that the attitude of Japanese towards Koreans has lately changed for the better. ... Further, in all branches of industry, such as agriculture, technical industry, and commerce, Japanese undertaking these employ many Koreans as their business assistants or workmen and there are also to be found many instances in which 
Japanese and Koreans are jointly undertaking business. . . . .33

Elsewhere the Report of the Government-General of Chosen speaks of the improvements which the Japanese have brought about in the industries of Chosen (Korea).

"The technical industry of Chosen was in a highly developed condition when the country was under the sway of the Koryo dynasty, but as a result of long years of maladministration it gradually declined and in recent years weaving, ceramics, manufacture of paper, metal work and a few other arts were the only branches of technical industry still remaining. These branches of industry were pursued on a very small scale, the workmanship was inferior and their production was small in amount. As it was, most of the commodities in daily use had to be imported from abroad. So, with the purpose of reviving the technical industry of old Korea, the former Korean Government, under the direction of the Residency-General, established, in 1907, a Technical Industrial Training Institute in Seoul, where weaving, dyeing, ceramics, metal and wood work and applied chemistry were taught to Korean students. . . . Necessary arrangements are in the course of being provided for, also carrying out examinations concerning weaving, dyeing, ceramics and applied chemistry ... and

${ }^{33}$ Results of Three Years' Administration of Chosen Since Annexation.

Published by the Government-General of Chosen, Seoul, 1914. Pp. 10-12. The ideals outlined here are of the highest. I am not able to vouch for the thoroughness with which they are put into execution. P. A. M. 
subsidies have been and are given to the work undertaken by public-spirited men for giving technical education to Koreans, as well as to various promising technical undertakings. . . ." 34

Directly one begins to study the government which Japan has erected in Korea or Chosen he realizes that the Japanese are, without doubt, the most conscious, conscientious, and thorough-going followers of the principles of race-appreciation in the world. At least they are so in theory, and I have never found an unprejudiced person who declared them to be otherwise in actual practice. The Japanese Government-General of Chosen has conducted an investigation of old usages which is officially described in these words:

"The business relating to investigation of old usages and institutions was formerly conducted by the Old Usage Investigation Bureau. As a result of the administrative readjustment, this business was transferred to the Councillors' Office of the Governor-General in April, I9I2, the Bureau at the same time being closed.

"These investigations not only furnished material of great import in effecting improvement in administrative measures in general, but also afforded many useful examples of the application of old usages which were of great assistance in administer-

${ }^{34}$ Results, etc., 1914, pp. $3 \mathrm{I}-33$. The facts given here, as well as the others embodied in this Report, indicate that the Japanese occupation of Chosen has been accompanied by a policy of the purest race-appreciation. Whatever of good was found in Korea was preserved, and the present Japanese government of Chosen seeks in every way to bring the Koreans to the cultural status they were in under the Koryo dynasty (918-1392) and to lead them into modern ways of life. 
ing justice to Koreans. Having in view the framing of laws or regulations concerning legal capacity, family relations, succession, wills, etc. of Koreans, investigation of these particular usages is continually going on, as is also investigation of other usages. The investigation is carried out not only by referring to old books or official documents, but by despatching officials to local districts for personal inspection of actual conditions existing in those localities. During the year 1912 such personal inspection or investigation was made in twelve seats of Provincial Governments besides twelve other localities. In addition, special investigation of special usages was also made in accordance with requests of administrative offices or law courts, and investigations so made during the year were nearly fifty in number. ... (Reference is here made to investigations carried out among the historical records and archives of the $\mathrm{Li}$ or $\mathrm{Yi}$ dynasty - I392-I9I0). ... The translation of an old Korean law encyclopædia, called the Tai-junboi-ton, into Japanese was completed in $191 \mathrm{I}$, but the revision and modification of it was commenced in 1912, and the work on the section dealing with the organic regulations of Government offices and of financial matters has already been completed." ${ }^{35}$

The activities here described compose a bit of pure and unalloyed race-appreciation of the noblest sort. A large portion of the world stands in urgent need of just this sort of policy.

35 Annual Report on Reforms and Progress in Chosen (Korea), (19121913). Issued by the Government-General of Chosen at Keijo (Seoul), December, 1914. (Quotation from p. 19.) 


\section{RACIAL FACTORS IN DEMOCRACY}

The Japanese in Chosen or Korea are by no means monopolizing the desirable official positions. Dr. Ladd says on this head:

"As might be expected, Japanese are principally employed in the most responsible places or positions requiring technical knowledge, while the Koreans are for the most part employed as assistants or subordinates. Yet all the members of the central council, five provincial governors out of thirteen, all the provincial councillors, all district magistrates, and all village headmen, are appointed exclusively from the native population. The number of government officials paid out of the government revenues in the fiscal year 1916 was 38,166 , of which 17,230 were natives." 36

In fine, the Japanese, though their colonizing methods are not superior to those of England and France, are more consciously and intensively applying the principles of race-appreciation. ${ }^{37}$

\section{F. The Anthropological Aspects of American Hawaii}

The first white man to visit Hawaii was probably Juan Gaetano, about 1555. For more than two centuries after that, however, these fertile, volcanic islands, tropical, but cool and salubrious, were unvisited by Europeans. In 1778 Captain Cook

\footnotetext{
36 Ladd, 1918, p. 437.

37 See also:

Hamilton, A.: Korea. London, 1903.

Griffs, W. E.: The Hermit Nation. New York, 1907.

Starr, Frederick: Korean Buddbism. Boston, 1918.
} 
rediscovered them, and in 1789 American influence became strong and has remained so ever since.

Like Algeria, Hawaii is characterized by the presence of a number of diverse ethnic groups.

THE POPULATION OF THE HAWAIIAN ISLANDS

Hawaiians and part-Hawaiians.......... 39,000

Chinese........................ 22,100

Japanese...................... 102,500

Filipinos...................... 19,000

Americans........................ 30,000

Others....................... 27,000

There is reason for supposing that in the days before missionaries came into the Islands the natives numbered at least 350,000 souls. The baleful effects of proselytizing unaccompanied by any real sympathy for or comprehension of the people and their needs, have reduced them to their present numbers. King Kamehameha I (1795-1819), aided by two American captains, Young and Davis, made good his rule over the whole archipelago and established a realm which gave great promise of cultural adaptability. Many of the interesting, and theoretically excellent agrarian and social institutions of the older and smaller chieftainships were used by Kamehameha. American influence made itself felt through the missionaries and through commerce. When the United States formally took the rulership of the Islands out of the hands of Queen Liliuokalani in August, I898, there was so little left of the native stock and its culture that there is now but slight need of race-appreciation as far as they are concerned. However, the arrival in the Islands of Jap- 


\section{RACIAL FACTORS IN DEMOCRACY}

anese, Chinese, Filipinos, and others has given rise to a new set of anthropological problems, most of them touching upon race-mixture and so on. There is hope that the remnant of the excellent Hawaiian stock may yet be preserved and augmented if a proper study of its characteristics and needs is carried out. ${ }^{38}$

\section{G. The Antbropological Aspects of the American Pbilippines}

The Philippine Islands are fertile volcanic islands with a tropical and humid environment.

The statistics as to population are not very accurate, as yet.

There are about $8,000,000$ people in the Islands, of whom about I I,000 are Americans and Europeans, about 35,000 are Chinese and the rest are natives (including some 25,000 negritos). ${ }^{39}$

As early as about 1435 the Filipinos had attained a stage of semicivilization through their incomplete contact with China. Several of the linguistic groups had their own systems of writing. Society was divided into three classes: Chiefs (three grades), freemen, and slaves. The family was the political unit, the barangay or clan being the division next above it. Though the freemen were often oppressed by their superiors, the slaves seem to have received remarkably mild treatment. There were fairly

${ }^{38}$ Carpenter, Edmund Janes: America in Hawaii. London, 1899. Pp. 2-16.

Alexander, W. D.: A Brief History of the Hawaiian People. New York, I891.

Liliuokalani, H. M. Queen: Hawaiï's Story. Boston, I898.

39 SYB, p. 6 I 8. 
good native laws. ${ }^{40}$ The agricultural methods of the Filipinos, especially their terraces, were good, and, in the hands of more vigorous folk, would have yielded much larger crops than they did.

All these native institutions Spain took over almost in bulk, the regular clergy frequently assuming the rank of chiefs so as to administer the people more effectively. The Filipinos, however, have long manifested a tendency toward political corruption, due to their excessive love of "playing politics." During the Spanish régime the Church was the dominant force, though after I810 some semblance of representative government came into being. ${ }^{41}$

Today the Filipinos, consisting of the Bisaya, the Tagalog, and six other stocks, all of which arrived in the Islands at different times, evince a growing ability to put themselves in the ways of modern civilization. The important question of whether or not the Filipinos be given independence is in a state of discussion best described as chaotic. Various political groups in this country are wrangling over it, but very little attention appears to be given to the discussion of what is best for the Filipinos. Meanwhile, the American government is doing, on the whole, excellent work as regards improving the condition of the native folk. Probably, in due course, the problem of independence will automatically solve itself. The chief arguments against

40 Robertson, James A.: The Social Structure of, and Ideas of Laro Among, Early Philippine Peoples. The Pacific Ocean in History, pp. 160-191. New York, 1917.

11 Robertson, James Alexander: The Evolution of Representation in the Philippine Islands. Journal of Race Development, VI, pp. 155-166. 1915. 


\section{RACIAL FACTORS IN DEMOCRACY}

giving the Philippines independence at once appear to be: (I) A lack of national feeling; (2) A lack of self-control and general ability; (3) A lack of a mass able to govern wisely; (4) The prevalence of ignorance, superstition, and illiteracy. ${ }^{42}$

If education and race-appreciation are allowed to assert their beneficial influences, these arguments will all presently lose their force. It is our duty as a generous-minded nation to do our best to act toward the Filipinos in as nearly the same manner as the Japanese act toward the Koreans as possible, so that we shall presently render them the independence which we have more than half promised them.

\section{OTHER ANTHROPOLOGICAL AND RACIAL FACTORS}

\section{IN COLONIZATION}

One of the most important problems that faces a colonizing nation with dependencies in an environment totally different from its own is that of whether or not acclimatability is possible for the colonists. Into this question all sorts of factors enter, such as the desirability of intermarriage with the natives, such as the general attitude of the colonists toward the natives and such as the physical characteristics of both human categories and of their surroundings.

Certain writers maintain that Europeans can never become really acclimatized in the tropics. ${ }^{43}$

${ }^{42}$ Worcester, Dean C.: The Philippines Past and Present. Vol. II, pp. 933-973. New York, 2 vols., 1914.

${ }^{43}$ Woodruff, Charles Edward: The Expansion of Races. New York, 1909. Pp. 242-245.

Orgeas, J.: La Patbologie des Races Humaines et le Problème de la Colonisation. Paris, 1886. Pp. 416-418. 
They argue that man, like the other animals, lives in environmental zones definitely established by Nature, and that he should not seek tc transcend the limitations set upon his movements. Dr. Woodruff made an exhaustive study of various more subtle bars to successful acclimatization, such as the effect of actinic rays in tropical light upon northern races. But he himself has shown that, to a very large extent, it is possible to counteract whatever evil influences may be exercised by tropical light by using the right sort of clothing, houses, and so on. Further, he draws attention to the fact that races which live in the hot, rarefied air of the tropics have broad nostrils and spacious nasal passages to enable them to take in the requisite amount of air, whereas the races that dwell in the dense cold atmosphere of the North have narrow nostrils and smaller nasal passages. The first half of this proposition is undoubtedly of considerable anthropological importance, but it is by no means obvious that the Eskimos have the type of nose which Dr. Woodruff's theory requires.

It is, of course, plain enough that most of the races native to the tropics are indolent, unprogressive, and gifted with little or no intellectual alertness. There is nothing in a tropical environment that would lead them by natural processes to become otherwise. Life is too easy to spur men on to effort. ${ }^{44}$ Indeed, history shows us a number of instances where tropical regions have had lymphatic inhabitants of low culture until, from some nontropical region adjacent, a new race with a high culture came in and created a civilization in spite of

"Ward, Robert DeCourcy: Climate. New York, 1918. Pp. 224-230. 
tropical conditions. Such cases are found in India and Egypt. On the other hand, it is also true that remarkable cultures have developed in tropical conditions and perished or transplanted themselves when the conditions altered. The pre-Columbian history of the Mayas shows us that. ${ }^{45}$

The other school of anthropological thought on this question is of the opinion that European man is acclimatable in the tropics, but it is recognized that special means must be adopted to hasten and perfect the acclimatization. M. Bordier, for example, is of the opinion that, both in Algeria and in Indo-China, marriages between French men and native women should be encouraged so that a mixed population having the mentality of the male parent and the physique of the female parent may be created. It is thought that such a population will be at once suited to tropical or semi-tropical conditions and intellectually fit for modern civilization. ${ }^{46}$ Indeed, the whole policy of the French government towards the natives of its colonies is one of fusion along these lines, for the two other possible policies (abstention from commingling with and complete obliteration of the natives) are equally frowned upon.

England, in contrast to France, adheres, as far as marriage and other alliances are concerned, to a policy of abstention toward the natives of her dependencies.

4s Huntington, Ellsworth: The Climatic Factor. Carnegie Institution of Washington, 1914. Civilization and Climate. New Haven, 1915. Pp. 242-244.

${ }_{46}$ Bordier, 1884, pp. 54 and $187-190$ and 395 .

Lanessan, 1897, pp. 26-28. 
Japan, in Chosen or Korea, approximates to the French policy.

The United States, in the Philippines, appears to have no fixed and formal policy in this connection. Our experience has been a peculiar one. The first groups of Americans to go out to the Philippines were almost exclusively males. They got on admirably well with the Filipinos, and happy marriages between American men and Filipinos were by no means infrequent. After American women began to arrive, however, the relations between them and the native women were such as to create a perceptible disharmony between the two groups of people. In some cases American women have married Filipinos while the latter were in America. All has gone well so long as the couple remained in this country, but as soon as they went to the Islands the wife would find herself snubbed and even ostracized by both Filipinos and Americans. ${ }^{47}$ For general social purposes, however, Americans and Filipinos associate on equality.

American and English and other anthropologists should make it their business to study this whole matter very exhaustively so as to ascertain what really is the best course to pursue.

\section{ADDENDUM TO CHAPTER VIII}

After the manuscript of this book was sent to the publisher, I chanced to run across a book which led me to think that possibly my picture of conditions in India was a little bit too sunny. ${ }^{48}$

47 I am indebted to Mr. James A. Robertson for this information.

48 Rai, Lajpat: England's Debt to India. New York, 1917. 


\section{RACIAL FACTORS IN DEMOCRACY}

The book is quite a recent one. On first taking it up, I thought that it was the work of some unprincipled agitator, but the further reading of the work, and the fact that its author bases his remarks almost entirely on the expressed opinions of Englishmen, soon convinced me that this was not the case.

Mr. Rai makes a large number of points; among the chief are these:

I. The population is immensely fecund, but the births are nearly outnumbered by the deaths. (Page 245.)

2. It is stated, on the authority of Sir William Hunter, that some $40,000,000$ people never satisfy their hunger. (Page 249.)

3. It is said that over $100,000,000$ people have an annual income of less than $\$ 5.00$. (Pages 249-250.)

4. There is said to be very widespread misery and poverty in India. (Pages 250-260.)

5. It is stated that between 1876 and 1900 there were eighteen famines resulting in deaths to the number of $26,000,000$ as against six famines with $5,000,000$ deaths between 1851 and 1875 and as against two famines with 500,000 between 1826 and 1850. (Pages 263-282.)

6. The conditions of the dwellers in the village communities are said to be exceedingly bad, hunger being very frequent.

I have discussed these points with several persons who know India well. The general consensus of opinion seems to be that:

I. The improvements in sanitation, policing, and living conditions effected by the British have 
lowered the death-rate to such an extent that the population is increasing with incredible speed.

2 and 3. That most of the people would rather tuck what money, especially gold, they have away in some corner, so that some day it may be beaten into bangles for their womenfolk, than they would eat a square meal, and that great amounts of coin are lost to circulation in this way, as well as through being given to idols or thrown down sacred wells.

4,5 , and 6 . That a large part of the misery of the people is directly caused by their own shiftless habits, and that most of the hunger is caused in the same way. Since 1900 the Government has built railways to such an extent that a real famine is now an impossibility. The figures given above take no account of the increase in population. Famines are not caused by overpopulation, but by failure on the part of the rivers to provide enough water for irrigation, by pests (locusts, fungi, etc.) and by similar natural catastrophes.

On the whole it seems likely that British administration in India, like every other human institution, is fallible. But it seems also likely that it is, on the whole, wonderfully able. 


\section{GENERAL CONCLUSIONS}

A. The Necessity of Having Race-Appreciation

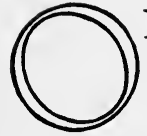

$\mathrm{NE}$ of the posters issued by the United States government for the purpose of stimulating public interest in the Third Liberty Loan bears the striking legend "To make the world a decent place to live in." Those words express what is undoubtedly the fundamental purpose of the best element in every Allied nation. Yet, in spite of this fact, the ideas which prevail as to what constitutes " a decent place to live in" are exceedingly discouraging to anyone who is so impractical as to have ideals. For several months I have been asking all sorts of people what their idea of "a decent place to live in" might be. One man thinks of it as a place where he can get free "beer and eats"; another man thinks of it as a place "where the income taxes are not so damned heavy"; a third thinks of it as a place where "the trains come in on time once in a while"; a fourth considers it a place "where weekend parties last from Thursday to Tuesday." So it goes. Out of several score of answers that I received from time to time to discreet questionings all save five or six had a similarly hideous and earthy tone of selfishness and materialism. The 
exceptions usually took the form of defining "a decent place to live in" as one where everyone got a "square deal."

A "square deal"! That is just what every man and woman, every nation and people, every culture and civilization, needs to have if democracy (real, in contradistinction to sham, democracy) is to be made a reality. If every individual, every nation, every culture, be given an opportunity to prove what good qualities it possesses and what task for society as a whole it is capable of performing; if every individual assume a place in the social scale in accordance with his or her proved qualities and capabilities; if mankind realize once and for all that to a social position which is lofty because its holder is a person of high ability there attaches an added obligation to be courteous, generous, upright, honest, unselfish, considerate, temperate in language and in act, brave, and self-sacrificing and that to a position which is humble because the holder's abilities are modest there attaches no disgrace or shame whatsoever; if these things and others of a kindred sort become social realities, then we shall begin to have real democracy. The anti-democratic forces at large in the world today are not inequality in social and political rank, paternalism, wealth and the possession of wealth, titles in recognition of merit, and kindred things; rather, the real antidemocratic forces are the hereditary principle, nepotism, unkindliness, materialism, Marxism, Bolshevikism, Teutonism, race-contempt, color-lines, cultural exclusiveness, and so on.

There is, unhappily, very little reason for believing 


\section{RACIAL FACTORS IN DEMOCRACY}

that any great proportion of the world's West European population is as yet ready for real democracy. Some lands, such as New Zealand, Switzerland, Denmark, Western Canada, parts of the United States, and Australia, seem to be ready, or very nearly ready, for it; indeed, the first three may be said already to possess it (save that Denmark still clings to the hereditary principle). I base this seemingly discouragistic statement on the fact that the countries named consist almost entirely of decent, upright, intelligent people. They have none (or almost none) of the undesirable rabble and the greedy, venal money-mad classes which are the masters of most modern lands, and which sway the unintelligent and indecent many according to their will; nor have they populations almost wholly several centuries behind the times. Real democracy can never exist in a country where most of the people are either unintelligent or indecent or both. It is not likely to exist in a country where either extreme wealth or extreme poverty prevail. It will find existence difficult in a land where men and women find it impossible to respect themselves if their position in life chances to be modest, or where men and women in high places look down with contempt upon those fellow human beings of theirs who happened to be less brilliantly endowed by Providence.

As every human being should have a "square deal," so should every culture and civilization; as every man or woman should have ample opportunity to prove himself or herself, so should every society and every human institution. When we of 
the white race of Europe humbly confess that we do not possess all the excellence in the world, and when we acknowledge that others may be able to teach us much that will help us, just as we teach them much that aids them, then, with the introduction of such race-appreciation, will come real world democracy. The planet will become a social constant, and a social whole.

B. The First Steps of Race-Appreciation in the Future

As already explained, race-appreciation has been going on subconsciously for uncounted centuries. The day of its conscious application to the world's affairs is only just now beginning to dawn.

I purpose here to examine critically several recent writings on the subject in hand. The first of these is a paper by Professor George H. Blakeslee, who says: ${ }^{1}$

"To make the world safe for democracy has come to be the ultimate purpose of the United States in the present war. ... In the public mind ... as revealed by newspapers and magazines... it is generally taken for granted that when the nations of the world are once democratic ... the world will ... be safe; great international wars will be at an end; universal militarism will pass away; and the nations will live together in peace and security. But is this impression correct, that democracy alone will make the world safe? If it is correct, then the great aim of America,

1 Blakeslee, George H.: Will Democracy Alone make the World Safe? Journal of Race Development, VIII, pp. 491-505. 1918. 


\section{RACIAL FACTORS IN DEMOCRACY}

a lasting peace, a non-militaristic world, will be secured by making all governments democratic, that is, responsible to their people. But if this impression is not correct, then the world may be made democratic without being made safe; the misery and the loss of the war may bring only a partial success, the righting of the immediate wrongs inflicted by Germany and Austria, but not the triumph of our ultimate aim, an abiding world peace.

". . . If democracies may be trusted to keep the peace this fact should be evident from a study of history. But even a hurried survey shows that, as a matter of fact, democracies have done their fair share of fighting, even of aggressive fighting. In classic Greece, at the height of its development, a large majority of its city states were democracies; yet they were not peaceful. They bled to death from the wounds which they inflicted on each other.... Y Yet the Athenian democracy was continually at war, not merely for defense, but aggressively to gain trade, commerce, and territory and from mere jealousy and pure lust of conquest. . . . This democratic imperialism was seen at its height in the attempt to conquer and annex Sicily.... There was no justification for it. Democratic Athens had less excuse for attacking Syracuse than autocratic Austria had for attacking Serbia. . . .

"The next imperialistic claimant for "the dominion of the western world' was also a democracy, the republic of Rome. After it had won control of Italy, largely by war and high-handed seizures of territory, it challenged Carthage to a life and death struggle for world sea power and empire. . . ." 
Professor Blakeslee then traces this principle down to Napoleonic times by way of Italy, the United Netherlands, the British Commonwealth, Switzerland, revolutionary France. He shows that democracies always have been both quarrelsome and selfishly aggressive. $\mathrm{He}$ then demonstrates the continuance of that truth during the last century of European and North American history. He then goes on to say:

"Even today the Monroe Doctrine contains seeds of possible trouble with other democracies since it is interpreted by many in this country as giving the United States a right to secure peculiar or artificial advantages in trade and commerce in South America. . . .

"During the past century, as is evident from this hasty sketch, the great democracies have been making war, threatening war, and preparing for war, much of the time against each other. . . . Each democracy becomes an excited partisan of its own view, ready to back it by force of arms; . . . There are enough conflicts in national policies today to lead to a dozen future conflicts, even if all the world should be democratic. . . ."

So much for Professor Blakeslee's adverse criticism. His constructive criticism is of equal value. $\mathrm{He}$ shows that democracies have been at odds and at war for generations until some outside force built up a union which wielded separate democracies into one democracy. Evidences of this truth are found in the history of the British Isles where today England and Scotland, once bitter foes, are practically one united democracy. The same thing is 
true of the United Kingdom of Italy and of the United States of North America. He then urges with all possible emphasis that peace, to be permanent, must be won through an international "concert of free peoples," or a "partnership of democratic nations."

This is undoubtedly the real foundation of lasting peace. The lack of a sympathetic understanding that shall transcend boundary lines has been the basic cause of the multitudinous wars which fill the pages of history. How can democracy win a true victory if there is no democracy between nation and nation?

Similarly, to extend the matter beyond the bournes of our own race and culture, how can real world democracy ever come into being so long as one race looks down upon, exploits and exterminates all the rest, obliterating both the evil and the good in their cultures by the enforced introduction of both the evil and the good in its own? How can a true democracy be created for the world unless every one of the world's peoples be given an equal chance to prove what degree of political, social and cultural virtue it may possess?

Finally, there is the all important question of paternalism and its relations to democracy. This is the time and the place to discuss but one phase of the matter - that which touches upon the attitude of our culture toward the other cultures in the world.

Everything in the preceding pages of this book points to the fact that some cultures are higher or more advanced or better fitted to do combat with 
Nature and her restrictions than are others. Likewise, it is clear that no culture, no matter how seemingly humble, is totally lacking in perfectibility, that no culture is entirely devoid of good qualities. Yet the task of the higher civilizations will be, in the immediate future, that of lifting up the lower cultures to their own level, and, at the same time, that of absorbing into themselves all that is best in the lower cultures to which they are giving of their own best. The reason why this twofold task will be accomplished and why the best of each culture and not - as hitherto - the worst will be exchanged, is this. Mankind is on the threshold of a new period in which ethical rectitude and conscious systematized efforts toward the destruction of existing evils will be the moving forces. In the past such ethical movements have frequently been witnessed. The movement which during the period between 1805 and 1865 strove successfully in England, the United States, and other countries to do away with slavery is an example. So also is the present-day agitation against child-labor, and that against intemperance, and that which, a few years ago, succeeded for a time in lessening the white slave traffic. In the past, however, such movements have been sporadic, and they have been accompanied by a bland toleration of conditions as bad or worse than those against which they were directed. There has been, in short, a lack in generality of scope in all such ethical movements. The aim has too often been that of stamping out one evil, rather than all evils. The ethical movement of which I speak will involve all 


\section{RACIAL FACTORS IN DEMOCRACY}

society, not merely sections of it; and it will aim to destroy all evils and all injustices, not merely some evils and some injustices.

One of the finest presentations of the problems of race-contact which has ever been written is that by Viscount Bryce. ${ }^{2}$ Lord Bryce says:

"To describe the phenomena of race-contact in our own time as marking a crisis may seem a strong expression, for such contact has never been interrupted since our palæolithic ancestors roamed hither and thither in search of wild fruits or wild creatures. There have been epochs, such as that of Alexander the Great, or that of Attila, or that which followed the discoveries made by Christopher Columbus, in which there has been a great impingement of some peoples upon other peoples which created new relations between them by way of conquest or settlement. But our own time stands eminent and peculiar in this, that it marks the completion of a process by which all the races of the world have been affected, and all the backward ones placed in a more or less complete dependence upon the more advanced. . . . The same forces or motives have worked to bring this result about which induced the conquests of earlier days. But two new factors have been more active and pervasive than before - the desire of civilized producers of goods to secure savage or semi-civilized customers by annexing the regions which they inhabit, and the rivalry of the great civilized States, each of

2 Bryce, James (Now Viscount Bryce): The Relations of the Advanced and Backward Races of Mankind. Oxford and London, 1902. (The Romanes Lecture.) Quotations from pp. 7-9 and p. 43. 
which has been spurred on by the fear that the others might appropriate the markets which it might win for itself. The process has been much swifter than was desirable in the interest of either conqueror or conquered. ... The completion of this Worldprocess is a specially great and fateful event, because it closes a page forever. The uncivilized and the semi-civilized races cannot relapse into their former isolation. In passing under the influences of the great Powers they have indeed given the world a new kind of unity. . . . It is hardly too much to say that for economic purposes mankind is fast becoming one people. ... The various races may, if friendly, help one another, more than ever before, and so accelerate the progress of the world. . .."

In these words Lord Bryce sums up the whole matter: He shows that mankind is already slowly unifying itself, and he emphasizes the need of friendliness (i.e., generosity, decency, square dealing) in human intercourse, especially between race and race.

In short, the task of the white race of Europe and of its civilization must be the paternalistic one of instructing the rest of the world in how to live cleanly, conveniently, comfortably, and systematically. Our material practicality is our greatest asset; it will be our greatest gift to world civilization; it will be the means of binding all the peoples of the planet together by infrangible bonds of commerce and by intangible (but no less mighty) bonds composed of ideas and ideals. It will prepare us, during the next few centuries, for whatever new trials an all-wise but unrelenting Providence may 


\section{RACIAL FACTORS IN. DEMOCRACY}

have in store for humanity, perhaps for combat with increasing polar ice-caps and all that they will mean, perhaps for interplanetary wars, perhaps for some sort of struggle of which we do not even dream today. While thus doing our share, however, we must not be blind to the qualities and the lore which we may acquire from our very pupils; cultural reciprocity and race-appreciation will be the cornerstones of the temple.

Turning our attention now to the more material and concrete tasks of race-appreciation, it will be well to consider what the more or less unconscious raceappreciation of the past, already has accomplished. Thereby it will be possible to gain some idea of what it will accomplish when it ceases to be unconscious and becomes conscious race-appreciation.

The gist of this aspect of race-appreciation - the material aspect - is contained in the words of Sir John Foster Fraser, who says: ${ }^{3}$

"Whenever I hear questioned the advantages of British rule in India I recall an experience. Years ago I crossed Persia. It was a country of glorious history, but seemed to have sunk to a state of repellant senility. It was as though a curse had fallen upon the land. The people were miserable and ill kempt. Modern architecture was debased. The famous cities of Teheran, Ispahan, and Shiraz had relics of past greatness, but they accentuated the sordidness of the present. There were no roads of merit; there were no railways whatever. In all my wanderings over half a hundred countries

${ }^{3}$ Fraser, Sir John Foster: The Future of India. Century Magazine, September, 1918, pp. 605-616. 
there was no region so wretchedly slothful and degraded as that of the shah.

"Then, as passing through a door, I entered India. It was a neighboring Eastern country, and many of the people were of the same race and the same Mohammedan faith; yet what a contrast! Great thriving commercial cities like Bombay, Calcutta, and Madras; a fine transcontinental railway system; excellent roads everywhere; areas of great industrial activity; all the towns well kept and decorated with exquisite gardens; on all sides an atmosphere of modernism, of stable government, of progress. I do not desire to make the comparison too marked, but I have often wondered whether Persia would have been as prosperous as India if the British had ruled it, and whether India would have degenerated to the position of Persia if left to itself.

Let me interpret the situation thus vividly laid before us by Sir John in the terms of race-appreciation. India had a marvelous civilization of her own, and admirable institutions, created by her peculiar needs. The British, on making themselves the masters of India, far from destroying this magnificent social and material fabric, preserved it, and added rich new elements derived from their own culture, elements which gave to India just those qualities which she needed to enable her to maintain her great position in the world. In other words, cultural reciprocity resulted in the creation of a hybrid civilization adapted to the needs of India as a modern nation. Persia, on the other hand, had no such advantages and no such 


\section{RACIAL FACTORS IN DEMOCRACY}

teachers. Consequently, although her position was once no less great than that of India, she fell further and further behind the march of the world. Hence arose her present state. But, as is often the case in race-appreciation, the pupil gave as much if not more than the teacher. Sir John continues:

"(India's) historical monuments are the most impressive in the world, revealing a long stretch of intensive culture. Indeed, the West owes much more to the East than the East owes to the West. From the East we get all our religion and most of our philosophy. In return we have given little more than mechanical devices and industrialism and such things which pass by the name of twentiethcentury civilization. And while it is true that there are millions of peasants in ignorance and superstition, it is not too much to say that in India are to be found men of scholarly attainments and animated by a beautiful idealism. ...."

It is fairly clear, then, from all that has been said, that the right sort of paternalism, as between the more advanced and the less advanced cultures of the world must prevail in the future; but it is equally clear that it must be accompanied by a generous-minded cultural reciprocity and race-appreciation. This is true in very many parts of the world. One has but to read dispassionately good books of history, geography and travel ${ }^{4}$ in order to perceive it.

4 As, for example, the following works:

Gaffarel, Paul: L'Algérie. Paris, I883.

Johnston, Sir Harry: A IIistory and Description of the British Empire in Africa. London, n.d. British Central Africa. London, 1898. 
So much, then, for the matter of what may be called external or international paternalism. Upon the vastly important but highly intricate subject of internal or inter-class paternalism and its very important task in the world I can touch only very briefly here. It is enough for me to say that in those countries where there is a great disparity between the general and intellectual culture of the highest class and those of the lowest or of the average or masses, paternalism will have a very definite job in bringing the quality of the masses up toward that of the best, and thereby preparing the people for the ultimate reception of democracy. What we must all realize today is the fact that democracy as we now have it is a very embryonic and imperfect thing, loaded down and encumbered with contradictions, crudities, and inconsistencies. That is probably because even the best of us today are not the equals of the masses of a few centuries hence; we are too deeply permeated with old selfishnesses and ancient mental or intellectual or spiritual evilnesses; as yet human nature is not much more perfect than it was half a million years ago; we think too well of ourselves and are much too bland and smug about our wretched little material achievements. We too often fail to realize that the men of the future will be far, far greater

Sykes, Sir Percy Molesworth: Ten Thousand Miles in Persia. New York, 1902.

Weigall, Arthur E. P. Brome: Egypt from 1798 to 1914. Edinburgh, 1915 .

Morel, E. D.: Nigeria: Its People and its Problems. London, 1912. Drake-Brockman, Ralph E.: British Somaliland. London, 1912.

Wylde, Augustus B.: Modern Abyssinia. London, 1901. 


\section{RACIAL FACTORS IN DEMOCRACY}

than we. Coupled with the deliberate ignoring of this truth is a tendency to deny the perfectibility of human nature. That tendency is a fundamental evil. Human nature is perfectible - as will quickly appear directly the best element of mankind sets itself the task of seriously improving human nature. In the perfecting of human nature paternalism, both the internal and the external varieties, will play an exceedingly important part, for through its means the now unworthy many will gradually be made the ethical and intellectual equals of the present best, and this applies to cultures in the world as a whole, as well as to classes in individual states.

It is a matter of extreme difficulty to decide which sort of paternalism - external or internal is to be the more important. The fundamental function of both kinds will be that of making the many (whether of cultures or of individuals) equal to the few, so that the undesirable elements may change from being a majority into being a minority. Certainly that can never take place while rancors, bitternesses, spleen and hate are at large in the world and predominantly the motivating forces therein. Let us hate only what is evil, let us joyfully cherish and love all that is good so that we may greet with clean souls the bright sun that will some day rise.

We North Americans and our friends of South America are faced today with the biggest opportunity for service to humanity that has ever faced any nation or any group of nations. In our eager plans for commercial and material aggrandizement 


\section{GENERAL CONCLUSIONS}

let us not forget the ideals of liberty voiced by Washington, fought for by him, by Lafayette and by the American armies of their date, let us not ignore the example set by Lincoln when he struck the shackles of slavery from the Negro, let each and every one of us do his part to aid America in leading the way toward a universal freedom and justice for all peoples whatever their condition and their history.

FINIS 



\section{BIBLIOGRAPHY}

\section{OF WORKS CONSULTED, REFERRED TO AND QUOTED}

[Thanks are due to Mrs. James Means who very kindly arranged and organized this bibliography.]

ALEXANDER, W. D.:

I89I A BRIEF HISTORY OF THE HAWAIIAN PEOPLE.

New York.

ALSTON, Leonard:

1907 THE WHITE MAN'S WORK IN ASIA AND AFRICA. London.

ALVA IXTLILXOCHITL, Fernando de:

1840 HISTOIRE DES CHICHIMEQQUES. Edited by $\mathrm{H}$. TERNAUX-COMPANS. Paris.

ALVARADO TEZOZOMOC, Fernando de:

I878-8I CRÓNICA MEXICANA. Edited by Manuel OROZCO Y BERRA. Mexico.

ALVAREZ, Francisco:

I88I NARRATIVE OF THE PORTUGUESE EMBASSY TO

ABYSSINIA, DURING THE YEARS $1520-1527$.

Edited by Lord STANLEY OF ALDERLEY. Hakluyt Society. London.

AMBROSETTI, Juan B.:

1905 ARQUEOLOGIA ARGENTINA; EL BRONCE EN LA REGION CALCHAQUI. Buenos Aires.

AMEGHINO, Florentino:

1878 L'HOMME PREHISTORIQUE DANS LE BASSIN DE LA PLATA.

Congrès international des sciences anthropologiques, pp. 341-350. Paris.

AMEGHINO, Florentino:

1879 LA PLUS HAUTE ANTIQUITÉ DE L'HOMME DANS

LE NOUVEAU-MONDE.

Congrès international des Américanistes, IInd Session, pp. 198-250. 
AMEGHINO, Florentino:

1880-81 LA ANTIGÚEDAD DEL HOMBRE EN LA PLATA. Paris. 2 vols.

ANCONA, Eligio:

I889 HISTORIA DE YUCATAN. Barcelona. 4 vols.

ANDERSON, C. L. G.:

I9II OLD PANAMA AND CASTILLA DEL ORO. Washington.

ANNUAL REPORT ON REFORMS AND PROGRESS IN CHOSEN (KOREA), (1912-1913).

Published by the Government-General of Chosen Keijo (Seoul), Dec., I9r4.

ANONYMOUS CONQUEROR, The:

I917 NARRATIVE OF SOME THINGS OF NEW SPAIN.

Translated and edited by Marshall H. SAVILLE. Cortes Society. New York.

ARCHER, William:

1917 INDIA AND THE FUTURE. London.

ARGUEDAS, Alcides:

I909 PUEBLO ENFERMO. Barcelona.

ARMSTRONG, John:

1752 HISTORY OF MENORCA. London.

ASAKAWA, K.:

I9I2 SOME CONTRIBUTIONS OF FEUDAL JAPAN TO THE NEW JAPAN.

Journal of Race Development, III, pp. I-33.

ASAKAWA, K.:

1914 THE ORIGIN OF FEUDAL LAND TENURE IN JAPAN.

American Historical Review, XX, pp. 1-23.

AYMONIER, Étienne:

1900-04 LE CAMBODGE. Paris. 3 vols.

AYRTON, E. R.: and LOAT, W. L. S.:

I9I I EL MAHARNA. London.

AZURARA, Gomes Eannes de:

I84I CHRONICA DO DESCOBRIMENTO E CONQUISTA DE GUINÉ.

Edited by the Vizconde de SANTAREM. Paris.

AZURARA, Gomes Eannes de:

1896-99 CHRONICLE OF THE DISCOVERY AND CONQUEST OF GUINEA.

Edited by Raymond BEAZLEY and Edgar PRESTAGE, Hakluyt Society, London. 2 vols. 
BADEN-POWELL, Baden H.:

I899 THE INDIAN VILLAGE COMMUNITY. London.

BAESSLER, Arthur:

1902-03 ANCIENT PERUVIAN ART. New York. 3 vols.

BALBOA, Miguel Cavello:

(See CAVELlO BALBOA, Miguel:)

BANCROFT, Hubert Howe:

I883 NATIVE RACES OF THE PACIFIC STATES. San Francisco. 5 vols.

BANDELIER, Adolph F.:

1878 ON THE DISTRIBUTION AND TENURE OF LANDS ... AMONG THE ANCIENT MEXICANS.

Peabody Museum (Harvard University), Cambridge (Mass.). BANDELIER, Adolph F.:

1879 SOCIAL ORGANIZATION AND MODE OF GOVERNMENT OF THE ANCIENT MEXICANS.

Peabody Museum (Harvard University), Cambridge (Mass.). BANDELIER, Adolph Francis:

1907 THE INDIANS AND ABORIGINAL RUINS NEAR CHACHAPOYAS, NORTHERN PERU. New York.

BANDELIER, Adolph Francis:

I910 THE ISLANDS OF TITICACA AND KOATI.

Hispanic Society of America. New York.

BANDELIER, Adolph Francis:

I9II THE RUINS AT TIAHUANACO.

American Historical Society. Worcester, (Mass.).

BARNETT, Lionel D.:

I9I4 ANTIQUITIES OF INDIA. London.

BASTIAN, Adolf:

1883 ZUR KENNTNISS HAWAIIS. Berlin.

BATES, Oric:

1914 THE EASTERN LIBYANS. London.

BATES, Oric:

1917 ANCIENT EGYPTIAN FISHING.

Harvard African Studies, I.

BATRES, Leopoldo:

1890 CLASIFICACIÓN DEL TIPO ÉTNICO DE LAS TRIBUS ZAPOTECAS. Mexico.

BATRES, Leopoldo:

1902 EXPLORACIONES DE MONTE ALBÁN. Mexico.

BEAZLEY, R.: and PRESTAGE, E.:

Edited AZURARA, 1896-99. 
BELAUNDE, Victor Andrés:

1908 EL PERÚ ANTIGUO Y LOS MODERNOS SOCIOLOGOS. Lima.

BENT, J. T.:

1893 THE SACRED CITY OF THE ABYSSINIANS. London. BERTHELOT, S.:

I879 ANTIQUITES CANARIENNES. Paris.

BERTHON, Paul:

I9II ETUDE SUR LE PRECOLOMBIEN DU BAS-PEROU. Paris.

BEUCHAT, Henri:

1912 MANUEL D'ARCHEOLOGIE AMERICAINE. Paris. BINGHAM, Hiram:

1913 THE WONDERLAND OF PERU.

National Geographic Magazine, April, 1913. Washington.

BINYON, Laurence:

1908 PAINTING IN THE FAR EAST. New York.

BLAKESLEE, George H.:

I918 WILL DEMOCRACY ALONE MAKE THE WORLD SAFE?

Journal of Race Development, VIII, pp. 49I-505.

BOAS, Franz:

1916 THE MIND OF PRIMITIVE MAN. New York.

BOMAN, Eric:

1908 ANTIQUITÉS DE LA REGION ANDINE . . . Paris. 2 vols.

BORDIER, A.:

1884 LA COLONISATION SCIENTIFIQUE. Paris.

BOWDITCH, Charles P.:

1910 THE NUMERATION, CALENDAR SYSTEMS AND ASTRONOMICAL KNOWLEDGE OF THE MAYAS. Cambridge, (Mass.).

BOWMAN, Isaiah:

I916 THE ANDES OF SOUTHERN PERU. New York.

BRASSEUR DE BOURBOURG, C. E.:

1857-59 HISTOIRE DES NATIONS CIVILISEES DU MEXIQUE ET DE L'AMERIQUE-CENTRALE. Paris. 4 vols. BRASSEUR DE BOURBOURG, C. E.:

Edited LANDA, 1864 .

BREASTED, James Henry:

1912 A HISTORY OF EGYPT. New York. 


\section{BIBLIOGRAPHY}

BRETON, Adela C.:

1906 SOME NOTES ON XOCHICALCO.

University of Pennsylvania, Philadelphia.

BRETON, Adela C.:

1906b THE WALL-PAINTINGS OF CHICHEN ITZA.

International Congress of Americanists, XVth Session, pp. 165-169.

BRIGHAM, William T.:

1899 HAWAIIAN FEATHERWORK.

Memoirs of the Bernice Pauahi Bishop Museum, I, Part I, Honolulu, H. I.

BRINKLEY, Francis:

190I-02 JAPAN; ITS HISTORY, ARTS and LITERATURE. Boston. 8 vols.

BRINKLEY, Francis:

1905 JAPAN. Tokyo. 12 vols.

BRINTON, Daniel Garrison:

1882 THE MAYA CHRONICLES. Philadelphia.

BRYCE, James: (Now Viscount Bryce.)

1902 THE RELATIONS OF THE ADVANCED AND BACKWARD RACES OF MANKIND. Oxford.

BUNAU-VARILLA Philippe:

I892 PANAMA, LE PASSE, LE PRESENT, L'AVENIR. Paris. BUSHELL, Stephen W.:

1904-06 CHINESE ART. London. 2 vols.

CALDECOTT, Alfred:

I9OI ENGLISH COLONIZATION ... London.

CAMBRIDGE MODERN HISTORY:

1909-I9I 2 New York. 14 vols.

CARPENTER, Edmund James:

1899 AMERICA IN HAWAII. London.

CARRUTHERS, Douglas:

1913 UNKNOWN MONGOLIA. London. 2 vols.

CARTAILHAC, Émile de:

1892 MONUMENTS PRIMITIFS DES BALEARES. Toulouse (France). 2 vols.

CARTAILHAC, Emile de: and BREUIL, Henri:

I906 LA CAVERNE D'ALTAMIRA. Monaco.

CASTANHOSO, Miguel de:

1902 THE PORTUGUESE EXPEDITION TO ABYSSINIA IN I54I-I543.

Edited by R. S. WHITEWAY. Hakluyt Society. London. 
CAVELLO BALBOA, Miguel:

1840 HISTOIRE DU PEROU. Edited by H. TERNAUXCOMPANS. Paris.

CERISIER, Charles:

I886 LA FRANCE ET SES COLONIES. Paris.

CHAILLEY-BERT, Joseph:

1892 LA COLONISATION DE L'INDO-CHINE. Paris.

CHAPIN, F. Stuart:

I9I3 SOCIAL EVOLUTION. New York.

CHAVANNES, Édouard:

1913 LES DOCUMENTS CHINOIS DECOUVERTS PAR AUREL STEIN DANS LES SABLES DU TURKESTAN ORIENTAL. Oxford.

CHIROL, Sir Valentine:

I918 ACCLIMATIZING DEMOCRACY IN INDIA.

Asia, XVIII, pp. 837-841.

CHRISTIAN, F. W.:

I899 THE CAROLINE ISLANDS. London.

CHURCHILL, William:

I9I I THE POLYNESIAN WANDERINGS.

Carnegie Institution of Washington, Publication No. 134.

Washington.

CHURCHILL, William:

I916 SISSANO: MOVEMENTS OF MIGRATION WITHIN AND THROUGH POLYNESIA.

Carnegie Institution of Washington, Publication No. 244. Washington.

CHURCHILL, William:

1917 CLUB TYPES OF NUCLEAR POLYNESIA.

Carnegie Institution of Washington Publication No. 255. Washington.

CIEZA DE LEÓN, Pedro de:

1883 CHRONICLE OF PERU. Edited by Sir Clements R. MARKHAM, Hakluyt Society, London.

CLAVIGERO, Francesco Saverio:

178I STORIA ANTICA DEL MESSICO. Cesena (Italy).

COBO, Bernabé:

1892 HISTORIA DEL NUEVO MUNDO. Edited by Marcos JIMENEZ DE LA ESPADA. Seville. 4 vols.

CODAZZI, A.: 
COEN, Gustavo:

190I LA QUESTIONE COLONIALE E I POPOLI DI RAZZA LATINA. Leghorn.

COOKE, George Alexander:

PHOENICIA, article on, in Encyclopaedia Britannica IIth Ed.

COOMARASWAMY, Ananda K.:

1913 THE ARTS AND CRAFTS OF INDIA AND CEYLON. London.

COOPER, John M.:

1917

ANALYTICAL AND CRITICAL BIBLIOGRAPHY OF THE TRIBES OF TIERRA DEL FUEGO AND ADJACENT TERRITORY.

Bureau of American Ethnology, Bulletin 63, Washington.

CORDIER, H.:

Edited: YULE, 1903.

COWAN, J.:

I9I0 THE MAORIS OF NEW ZEALAND. Wellington (New Zealand).

CRAIG, James Alexander:

Edited: WINCKLER, 1907.

CRAM, Ralph Adams:

'1917 THE NEMESIS OF MEDIOCRITY. Boston.

CRAWFORD, M. D. C.:

I9I5 PERUVIAN TEXTILES.

Anthropological Papers, American Museum of Natural History, XII, Part iii, New York.

CRAWFORD, M. D. C.:

1916 PERUVIAN FABRICS.

Anthropological Papers, American Museum of Natural History, XII, Part iv, New York.

CROMER, The Earl of:

1908 MODERN EGYPT. New York. 2 vols.

CUNOW, Heinrich:

1898 DIE SOZIALE VERFASSUNG DES INKAREICHS. Brunswick.

CZAPLICKA, M. A.:

I914 ABORIGINAL SIBERIA. Oxford.

DALL, William H.:

1877 ON THE SUCCESSION IN THE SHELL-HEAPS OF THE ALEUTIAN ISLANDS. Washington. 
DALL, William H.:

I880 ON THE REMAINS OF LATER PRE-HISTORIC MAN ... IN THE CATHARINE ARCHIPELAGO, ALASKA. Smithsonian Contributions to Knowledge, XXII. Washington.

DALL, William H.:

I886 THE NATIVE TRIBES OF ALASKA.

Proceedings of the American Association for the Advancement of Science (1886), pp. 363-38r.

DARWIN, Charles:

I859 THE ORIGIN OF SPECIES. London.

DARWIN, Charles:

187I THE DESCENT OF MAN. London. 2 vols.

DAWSON, C.

1913 ON THE DISCOVERY OF A PALAEOLITHIC HUMAN SKULL . . . AT PILTDOWN.

Quarterly Journal of the Geological Society, LXIX, pp. 117-151. London.

DAWSON, C.

I9I3b PREHISTORIC MAN IN SUSSEX.

Zoologist, Series 4, XVII, pp. 33-36. London.

DEBENEDETTI, Salvador:

I9I2 INFLUENCIAS DE LA CULTURA DE TIAHUANACO ... EN EL NOROESTE ARGENTINO. Buenos Aires.

DECHELETTE, J.

19I0-13 MANUEL D'ARCHEOLOGIE PREHISTORIQUE, CELTIQUE ET GALLO-ROMAINE. Paris. 4 vols.

DENNIS, George:

I878 CITIES AND CEMETERIES OF ETRURIA. London. 2 vols.

DIAZ DEL CASTILLO, Bernal:

1908-16 A TRUE HISTORY OF THE CONQUEST OF NEW SPAIN. Translated and edited by Alfred Percival MAUDSLAY. Hakluyt Society, London. 5 vols.

DICK, Frederick J.:

1915 NOTES ON PERUVIAN ANTIQUITIES.

Papers of the School of Antiquity, No. 3. Point Loma, California.

DICKSON, W. P.:

Edited: MOMMSEN, 1903. 


\section{BIBLIOGRAPHY}

DILKE, Sir Charles Wentworth:

I910 FORCED AND INDENTURED LABOUR IN SOUTH AMERICA, In NATIONALITIES AND SUBJECT RACES, pp. 99-106, London.

DIXON, Roland Burrage:

1912 THE INDEPENDENCE OF THE CULTURE OF THE AMERICAN INDIAN.

Science, N. S., XXXV, pp. 46-55.

DIXON, Roland Burrage:

1916 OCEANIC MYTHOLOGY. Volume IX of the mythologies of all races series. Boston.

DIXON, Roland Burrage:

1916b THE SWAN-MAIDEN THEME IN THE OCEANIC AREA.

Holmes Anniversary Volume, pp. 80-87. Washington.

DOMVILLE-FIFE, Charles W.:

I9IO THE GREAT STATES OF SOUTH AMERICA. London. DORSEY, George A.:

I901 ARCHAEOLOGICAL INVESTIGATIONS ON THE ISLAND OF LA PLATA, ECUADOR.

Field Museum. Chicago.

DRAKE-BROCKMAN, Ralph E.:

1912 BRITISH SOMALILAND. London.

DUBOIS, Eugen:

I894 PITHECANTHROPUS ERECTUS, EINE MENSCHENAEHNLICHE UEBERGANGSFORM AUS JAVA. Batavia.

DUBOIS, Marcel:

I895 SYSTEMMES COLONIAUX. Paris.

DUCHESNE-FOURNET:

1909 MISSION EN ÉTHIOPIE. Paris. 2 vols.

DUTT, Romesh Chunder:

1906 HISTORY OF INDIA FROM THE EARLIEST TIMES

DOWN TO THE SIXTH CENTURY B. C. London.

EATON, George F.:

1916 THE COLLECTION OF OSTEOLOGICAL MATERIAL FROM MACHU PICCHU. Memoirs of the Connecticut Academy of Arts and Sciences, V. New Haven (Conn.).

EDGE-PARTINGTON, James:

I890 ALBUMS. Manchester (England). 2 vols.

EDGE-PARTINGTON, James:

1895 ALBUMS. Second Series. Manchester (England). 
EDGE-PARTINGTON, James:

1898 ALBUMS. Third Series. Manchester (England).

ESPINOSA, Alonso de:

1907 THE GUANCHES OF TENERIFE. Translated and ed. ited by Sir Clements R. MARKHAM. Hakluyt Society, London.

EVANS, Maurice S.:

19II BLACK AND WHITE IN SOUTH EAST AFRICA. London.

EVANS, Maurice S.:

1915 BLACK AND WHITE IN THE SOUTHERN STATES. London.

FAIDHERBE, L. L. C.:

1873

INSTRUCTIONS SUR L'ANTHROPOLOGIE DE L'ALGÉRIE.

Bulletin de la Société d'Anthropologie de Paris, and Series, VIII, p. $603 \mathrm{ff}$.

FERRERO, Guglielmo:

1902 GRANDEZZA E DECADENZA DI ROMA. Milan. 2 vols.

FERRERO, Guglielmo:

I918 EUROPE'S FATEFUL HOUR. New York.

FIRMIN, A.:

I885 DE L'EGALITE DES RACES HUMAINES. Paris.

FLOWERS, Montaville:

I9I7 THE JAPANESE CONQUEST OF AMERICAN OPINION. New York.

FORNANDER, A.:

1878-85 ACCOUNT OF THE POLYNESIAN RACE AND THE ANCIENT HISTORY OF THE HAWAIIAN PEOPLE. London. 3 vols.

FOURNEREAU, Lucien: and PORCHER, Jacques:

1890 LES RUINES D'ANGKOR. Paris.

FRANK, Tenney:

I9I4 ROMAN IMPERIALISM. New York.

FRASER, Sir John Foster:

I9I8 THE FUTURE OF INDIA.

Century Magazine, September, 1918, pp. 605-616

FREIRE, Candido L.:

I858 VIDA DO INFANTE D. HENRIQUE. Lisbon.

FRIEDERICI, Georg:

1907 DIE SCHIFFAHRT DER INDIANER. Stuttgart. 
FRIEDERICI, Georg:

1915 EIN BEITRAG ZUR KENNTNISS DER TRUTZWAFFEN DER INDONESIER SUEDSEEVOELKER UND INDIANER.

Baessler-Archiv, VII, Leipzig.

GAFFAREL, Paul:

1883 L'ALGERIE. Paris.

GAMIO, Manuel:

I916 FORJANDO PATRIA. Mexico.

GARCILASSO DE LA VEGA, El Ynca:

1869-7I ROYAL COMMENTARIES OF THE YNCAS. Edited by Sir Clements R. MARKHAM, Hakluyt Society, London. 2 vols.

GARCILASO DE LA VEGA:

I9I8 LOS COMENTARIOS REALES DE LOS INCAS. Edited by Horacio H. URTEAGA. Lima.

GARSTANG, John:

I9IO THE LAND OF THE HITTITES. London.

GATES, William E.:

I9I6 EARLY CHINESE PAINTING.

Point Loma (California).

GIBBON, Edward:

1783-90 THE HISTORY OF THE DECLINE AND FALL OF THE ROMAN EMPIRE. London 12 vols.

GIDDINGS, Franklin Henry:

1900 DEMOCRACY AND EMPIRE. New York. GIDDINGS, Franklin Henry:

1917 AMERICANISM IN WAR AND PEACE.

Clark University Library Publications, V, No. 5. Worcester (Mass.).

GILES, Herbert A.:

I9II THE CIVILIZATION OF CHINA. London.

GOLDENWEISER, A. A.:

1916 DIFFUSION VS. INDEPENDENT ORIGIN: A REJOINDER TO PROF. G. ELLIOT SMITH.

Science, N. S., XLIV, pp. 531-533.

GONZALEZ DE LA ROSA, Manuel:

1908 LES DEUX TIAHUANACO ...

International Congress of Americanists, XVIth Session, pp. $405-428$. 
GONZALEZ DE LA ROSA, Manuel:

1909 ENSAYOS DE CRONOLOGIA INCANA.

Revista Historica, IV, trimestres $i$ and ii. Lima.

GONZALEZ SUAREZ, Federico:

1890-1903 HISTORIA GENERAL DEL ECUADOR. Quito. 7 vols. GONZALEZ SUAREZ, Federico:

1892 ATLAS ARQUEOLÓGICO. Quito. 2 vols.

GORDON, George Byron:

I899 THE RUINED CITY OF COPAN.

Bulletin of the American Geographical Society, XXXI, pp. 39ff. New York.

GOSSE, A. Bothwell:

N. D. THE CIVILIZATION OF THE ANCIENT EGYPTIANS. New York.

GRAEBNER, Fritz:

1909 DIE MELANESISCHE BOGENKULTUR UND IHRE VERWANDTEN.

Anthropos, IV, pp. 726-780; 998-1032.

GRAHAM, Alexander:

1902 ROMAN AFRICA. London.

GRENIER, Albert:

I9I2 BOLOGNE VILLANOVIENNE ET ETRUSQUE. Paris. GRIFFIS, W. E.:

1907 THE HERMIT NATION. New York.

GULICK, Sidney L.

19I8 AMERICAN DEMOCRACY AND ASIATIC CITIZENSHIP. New York.

HALL, Edith H.:

1905 EARLY PAINTED POTTERY FROM GOURNIA, CRETE.

Transactions, Department of Archaeology, Free Museum of Science and Art (1905), pp. 19I-205. Philadelphia.

HALL, G. Stanley:

I9I0 THE POINT OF VIEW TOWARD PRIMITIVE RACES. Journal of Race Development, I, pp. 5-I2.

HALL, H. R.:

I915 AEGEAN ARCHAEOLOGY. London.

HALL, Richard N.:

1909 PRE-HISTORIC RHODESIA. London.

HAMILTON, Angus:

I9Io KOREA. Boston. 
HAMILTON, Augustus:

I896 MAORI ART. Dunedin (New Zealand).

HAVELL, E. B.:

1908 INDIAN SCULPTURE AND PAINTING. London.

HAVELL, E. B.:

N. D. THE IDEALS OF INDIAN ART. New York.

HAWES, Harriet Boyd:

1908 GOURNIA. Philadelphia.

HEDIN, Sven:

I899 THROUGH ASIA. New York. 2 vols.

HIRTH, Friedrich:

I908 THE ANCIENT HISTORY OF CHINA. New York.

HOLMES, William H.:

I885 ANCIENT ART OF THE PROVINCE OF CHIRIQUI.

Report of the Bureau of American Ethnology for $188_{4}-85$, pp. 3-r87. Washington.

HOLMES, William H.:

1895-97 ARCHAEOLOGICAL STUDIES AMONG THE ANCIENT CITIES OF MEXICO.

Field Museum, Chicago.

HOLMES, William H.:

1916 THE OLDEST DATED AMERICAN MONUMENT.

Art and Archaeology, III, pp. 275-278.

HOLMES, William H.:

I9r6b THE GREAT DRAGON OF QUIRIGUA.

Art and Archaeology, IV, pp. 269-280.

HOOTON, Ernest Albert:

I9I6 PRELIMINARY REMARKS ON THE ARCHEOLOGY AND PHYSICAL ANTHROPOLOGY OF TENERIFE.

American Anthropologist, N. S., XVIII, pp, 358-365.

HOPKINS, E. Washburn:

I901 INDIA OLD AND NEW. New York.

HOTTEN, John Camden:

1868 ABYSSINIA. London.

HRDLIČKA, Aleš:

I9II SOME RESULTS OF RECENT ANTHROPOLOGICAL EXPLORATION IN PERU.

Smithsonian Miscellaneous Publications, LVI, No. 16. Washington.

HRDLIČKA, Aleš: and WILLIS, Bailey:

1912 EARLY MAN IN SOUTH AMERICA.

Bureau of American Ethnology, Bulletin 52. Washington. 
HRDLIČKA, Aleš:

I9I2 RESTES DANS L'ASIE ORIENTALE DE LA RACE QUI A PEUPLE L'AMERIQUE.

Congrès international d'anthropologie et d'archéologie préhistoriques, XIVth Session, pp. 409-4I4.

HRDLIČKA, Aleš:

1914 THE MOST ANCIENT SKELETAL REMAINS OF MAN.

Smithsonian Report for 1913, pp. 491-552. Washington.

HRDLIČKA, Aleš:

1915 THE PEOPLING OF AMERICA.

Journal of Heredity, VI, pp. 79-91. Washington.

HRDLICKA, Aleš:

1917 TRANSPACIFIC MIGRATIONS.

Man, XVII, pp. 29-30. London.

HRDLIČKA, Aleš:

1917b THE GENESIS OF THE AMERICAN INDIAN.

International Congress of Americanists, XIXth Session, pp. 559-568.

HUMPHREY, Seth K.:

1917 MANKIND. New York.

HUNTINGTON, Ellsworth:

1914 THE CLIMATIC FACTOR.

Carnegie Institution of Washington, Publication No. 192. Washington, D. C.

HUNTINGTON, Ellsworth:

1915 CIVILIZATION AND CLIMATE. New Haven.

HUNTINGTON, Ellsworth:

19I5 CIVILIZATION AND CLIMATE. New Haven (Conn.)

IRELAND, Alleyne:

I899 TROPICAL COLONIZATION. New York.

IRELAND, Alleyne:

I905 THE FAR EASTERN TROPICS. Boston.

IXTLILXOCHITL, Fernando de Alva:

(See ALVA IXTLILXOCHITL, Fernando de:)

JIJÓN Y CAAMAÑO, Jacinto:

1914 ABORÍGENES DE IMBABURA. Quito.

JIMENEZ DE LA ESPADA, Marcos:

I879 TRES RELACIONES DE ANTIGÜEDADES PERUANAS. Madrid. 
JIMENEZ DE LA ESPADA, Marcos:

Edited: MONTESINOS, 1882.

$\mathrm{COBO}, 1892$.

JOHNSTON, Sir Harry:

N. D. A HISTORY AND DESCRIPTION OF THE BRITISH EMPIRE IN AFRICA. London.

JOHNSTON, Sir Harry:

1898 BRITISH CENTRAL AFRICA. London.

JONES, Chester Lloyd:

1912 REPUBLICAN GOVERNMENT IN CHINA.

Annals of the American Academy of Political and Social

Sciences, XXXIX, pp. 26-38. West Philadelphia.

JOYCE, Thomas A.:

I912 SOUTH AMERICAN ARCHAEOLOGY. London.

JOYCE, Thomas A.:

1914 MEXICAN ARCHAEOLOGY. New York.

JOYCE, Thomas A.:

I916 CENTRAL AMERICAN AND WEST INDIAN ARCHAEOLOGY. New York.

KALLEN, Horace Meyer:

1918 THE STRUCTURE OF LASTING PEACE. Boston.

KELLER, Albert Galloway:

IgO8 COLONIZATION. Boston.

KENNEDY, Sinclair:

1914 THE PAN-ANGLES. New York.

KIDD, Benjamin:

I898 THE CONTROL OF THE TROPICS. New York.

KIDD, Benjamin:

1898b SOCIAL EVOLUTION. New York.

KIDD, Benjamin:

1902 PRINCIPLES OF WESTERN CIVILISATION. New York.

KIDD, Benjamin:

I9I8 THE SCIENCE OF POWER. New York.

KRAEMER, Augustus:

1905 DER HAUS- UND BOOTBAU SAMOAS. Berlin.

KUBARY, J. A.:

1889-92 ETHNOGRAPHISCHE BEITRAEGE ZUR KENNTNISS DES KAROLINEN-ARCHIPEL. Leiden. 4 vols. 
LADD, George Trumbull:

I918 THE DEVELOPMENT OF KOREA IN MOST RECENT TIMES.

Journal of Race Development, VIII, pp. 43I-438.

LANDA, Diego de:

I864 RELACIÓN DE LAS COSAS DE YUCATAN.

Edited by BRASSEUR DE BOURBOURG. Paris.

LANESSAN, J.-L. de:

I897 PRINCIPES DE LA COLONISATION. Paris.

LANUX, Pierre de:

1917 NEW FRANCE AND YOUNG AMERICA. New York.

LAUFER, Berthold:

1913 PLATE ARMOR IN AMERICA.

American Anthropologist, N. S., XV, pp. 96-97.

LAUFER, Berthold:

I9I4 SOME FUNDAMENTAL IDEAS OF CHINESE CULTURE.

Journal of Race Development, V, pp. 160-174.

LAVISSE, Ernest: and RAMBAUD, A.:

1894 HISTOIRE GENERALE DU IVe SIÈCLE A NOS JOURS.

Paris. 12 vols.

LECKY, William Edward Hartpole:

I899 DEMOCRACY AND LIBERTY. New York. 2 vols.

LEE-WARNER, Sir William:

I894 THE PROTECTED PRINCES OF INDIA. London.

LEONG, Y. K.: and TAO, L. K.

I915 VILLAGE AND TOWN LIFE IN CHINA. London.

LEWIS, Sir George Cornewall:

I90I GOVERNMENT OF DEPENDENCIES. Edited by Jacob Gould SCHURMAN. New York.

LILIUOKALANI, H. M. Queen:

1898 HAWAII'S STORY. Boston.

LORINI, Eteocle:

1900 LA PERSIA ECONOMICA CONTEMPORANEA E LA SUA QUESTIONE MONETARIA. Rome.

LOWIE, Robert H.:

I917 CULTURE AND ETHNOLOGY. New York.

LUMMIS, Charles Fletcher:

I916 WHERE THE STONES COME TO LIFE.

Art and Archaeology, IV, pp. 281-289.

LYTHGOE, Albert M.: and RANSOM, Caroline L.:

1916 THE TOMB OF PERNEB. Metropolitan Museum of Art, New York. 


\section{BIBLIOGRAPHY}

MACCURDY, George Grant:

1905 THE EOLITHIC PROBLEM.

American Anthropologist, N. S., VII, pp. 425-479.

MACCURDY, George Grant:

I9I I A STUDY OF CHIRIQUIAN ANTIQUITIES.

Memoirs of the Connecticut Academy of Arts and Sciences, III, New Haven (Conn.)

MAINE, Sir Henry Sumner:

1907 ANCIENT LAW. London.

MAJOR, R. H.:

1868

THE LIFE OF HENRY OF PORTUGAL SURNAMED THE NAVIGATOR. London.

MALER, Teobert:

I908 EXPLORATIONS IN THE DEPARTMENT OF PETEN, GUATEMALA.

Peabody Museum (Harvard University), Memoirs, IV, No. 2. Cambridge (Mass.).

MALLOCK, W. H.:

IgI8 THE LIMITS OF PURE DEMOCRACY. New York. MARKHAM, Sir Clements R.:

Edited: GARCILASSO DE LA VEGA, 1869-71.

CIEZA DE LEÓN, I883.

SARMIENTO DE GAMBOA, 1907.

ESPINOSA, 1907.

MARKHAM, Sir Clements R.:

1904 THE MEGALITHIC AGE IN PERU.

International Congress of Americanists, XIVth Session, ii, pp. 521-529.

MARKHAM, Sir Clements R.:

I9O8 MAJORCA AND MINORCA. London.

MARKHAM, Sir Clements R.:

1908 A COMPARISON OF THE ANCIENT PERUVIAN

CARVINGS ON THE STONES OF TIAHUANACO AND CHAVIN.

International Congress of Americanists, XVIth Session, pp. 389-395.

MARKHAM, Sir Clements R.:

I9I0 THE INCAS OF PERU. New York.

MARKHAM, Sir Clements R.:

1912 THE CONQUEST OF NEW GRANADA. London.

MARTIN, Alfred W.:

I9I I GREAT RELIGIOUS TEACHERS OF THE EAST. New York. 
MASON, Otis Tufton:

I894 WOMAN'S SHARE IN PRIMITIVE CULTURE. New York.

MAUDSLAY, Alfred Percival:

1889-1902 BIOLOGIA CENTRALI-AMERICANA, ARCHAEOLOGY. London. 4 vols.

MAUDSLAY, Alfred Percival:

Edited: DIAZ DEL CASTILLO, I908-1916.

MEANS, James:

Editor of AERONAUTICAL ANNUAL, 1895, I896, I897, and of the EPITOME OF THE AERONAUTICAL ANNUAL, I9Io.

MEANS, Philip Ainsworth:

1916 SOME OBJECTIONS TO MR. ELLIOT SMITH'S THEORY.

Science, N. S., XLIV, pp. 533-534.

MEANS, Philip Ainsworth:

1917

HISTORY OF THE SPANISH CONQUEST OF YUCATAN AND OF THE ITZAS.

Papers of the Peabody Museum (Harvard University), VII. Cambridge (Mass.).

MEANS, Philip Ainsworth:

1917b REALISM IN THE ART OF ANCIENT PERU.

Art and Archaeology, VI, pp. 235-246.

MEANS, Philip Ainsworth:

I9I7C AN OUTLINE OF CULTURE SEQUENCE IN THE ANDEAN AREA.

International Congress of Americanists, XIXth Session, pp. 236-252.

MEANS, Philip Ainsworth:

1917d A NOTE ON THE GUARANI INVASIONS OF THE INCA EMPIRE.

Geographical Review, IV, pp. 482-484. New York.

MEANS, Philip Ainsworth:

I917e A SURVEY OF ANCIENT PERUVIAN ART.

Transactions of the Connecticut Academy of Arts and Sciences, XXI, pp. 315-442. New Haven (Conn.)

MEANS, Philip Ainsworth:

I9I8 LAS RELACIONES ENTRE CENTRO-AMERICA Y SUD-AMERICA EN LA EPOCA PREHISTÓRICA.

Boletín de la Sociedad Geográfica de Lima, XXXIII, pp. 151-170. 
MEANS, Philip Ainsworth:

19r8b RACE-APPRECIATION IN LATIN AMERICA.

Science, N. S., XLVIII, pp. 256-260.

MEANS, Philip Ainsworth:

1918c SOCIAL CONDITIONS IN THE PIURA-TUMBES

REGION OF NORTHERN PERU.

The Scientific Monthly, vii pp. 385-399.

MEANS, Philip Ainsworth:

1918d RACE APPRECIATION AND DEMOCRACY.

Journal of Race Development, IX.

MEANS, Philip Ainsworth:

Edited SANCHO, 1917.

MILLARES CUBAS, A.:

1893-95 HISTORIA GENERAL DE LAS ISLAS CANARIAS.

Las Palmas (Canary Islands). Io vols.

MILLIS, H. A.:

1918 THE JAPANESE PROBLEM IN THE UNITED STATES.

New York.

MINNS, Ellis H.:

1913 SCYTHIANS AND GREEKS. Oxford.

MOLINA SOLIS, J. F.:

1897 HISTORIA DEL DESCUBRIMIENTO Y CONQUISTA

DE YUCATAN. Mérida (Yucatan).

MOMMSEN, Theodor:

1856-85 RÖMISCHE GESCHICHTE. Berlin. 4 vols.

MOMMSEN, Theodor:

1903 THE HISTORY OF ROME. Edited by William Purdie DICKSON. New York. 5 vols.

MONTELIUS, Oscar:

1906 KULTURGESCHICHTE SCHWEDENS VON AELTESTEN ZEITEN. Leipzig.

MONTESINOS, Fernando:

1882 HISTORIA ANTIGUA DEL PERÚ. Edited by Marcos JIMENEZ DE LA ESPADA. Madrid.

MOOKERJI, Radhakumud:

1912 INDIAN SHIPPING. Bombay and London.

MOOKERJI, Radhakumud:

1914 THE FUNDAMENTAL UNITY OF INDIA. London.

MOOREHEAD, Warren K.:

1914 THE AMERICAN INDIAN. Andover (Mass.).

MOREL, E. D.:

1912 NIGERIA: ITS PEOPLE AND ITS PROBLEMS. London. 
MORGAN, J. de:

1902 L'HISTOIRE D'ELAM. Paris.

MORLEY, Sylvanus Griswold:

I913 ARCHAEOLOGICAL RESEARCH AT THE RUINS OF CHICHEN ITZA, YUCATAN.

Carnegie Institution of Washington, Publication No. 200, pp. 61-9r. Washington.

MORLEY, Sylvanus Griswold:

1915 AN INTRODUCTION TO THE STUDY OF MAYA HIEROGLYPHS.

Bureau of American Ethnology, Bulletin 57. Washington. MOURA, L.:

1883 LE ROYAUME DE CAMBODGE. Paris.

MUNRO, Neil Gordon:

I9I I PHEHISTORIC JAPAN. Yokohama.

MUNRO, Robert:

I882 ANCIENT SCOTTISH LAKE-DWELLINGS OR CRANNOGS. Edinburgh.

MUNRO, Robert:

1890 THE LAKE-DWELLINGS OF EUROPE. London.

NATIONALITIES AND SUBJECT RACES. London.

(The Report of a Conference held in London, June, 1910.)

NEWELL, Edward T.:

1916 THE DATED ALEXANDER COINAGE OF SIDON AND AKE. New Haven.

NORDENSKIÖLD, Baron Erland:

1906 ARKEOLOGISKA URDERSOKNINGAR IN PERUS OCH BOLIVIAS. Stockholm.

NORDENSKIÖLD, Baron Erland:

1917 THE GUARANI INVASION OF THE INCA EMPIRE.

Geographical Review, IV, pp. 103-12I.

NORDENSKIÖLD, Baron Erland:

I9I7b DIE OESTLICHE AUSBREITUNG DER TIAHUANACOKULTUR . . .

Zeitschrift fuer Ethnologie.

NORTON, Richard:

ETRURIA, Article on, Encyclopaedia Britannica, IIth Edition.

NUTTALL, Zelia:

I886 THE TERRA COTTA HEADS OF TEOTIHUACAN.

American Journal of Archaeology, II, pp 157-178; 318-330. 
NUTTALL, Zelia:

I888 STANDARD OR HEADDRESS?

Peabody Museum (Harvard University), Papers, I, pp. 568. Cambridge (Mass.).

ORGEAS, J.:

I886 LA PATHOLOGIE DES RACES HUMAINES ET LE PROBLEME DE LA COLONISATION. Paris.

OROZCO Y BERRA, Manuel:

Edited: ALVARADO TEZOZOMOC, 1878-81.

OROZCO Y BERRA, Manuel:

I880 HISTORIA ANTIGUA DE LA CONQUISTA DE MEXICO. Mexico. 4 vols.

OSBORN, Henry Fairfield:

I9I5 MEN OF THE OLD STONE AGE. New York.

OYARZÚN, Aurelio:

I910 CONTRIBUCIÓN AL ESTUDIO DE LA INFLUENCIA DE LA CIVILIZACIÖN PERUANA SOBRE LOS INDIGENAS DE CHILE.

International Congress of Americanists, XVIIth Session, pp. 354-397.

PAIS, Ettore:

I9I3 STORIA CRITICA DI ROMA. Rome.

PAREDES, M. Rigoberto:

I9I I ALTIPLANICIE PACEÑA.

Boletén de la Sociedad Geográfica de La Paz, IX, pp. 19-57;

PARIS, Pierre: I30-I 45 .

1903 ARCHEOLOGIE EN ESPAGNE. Paris. 2 vols.

PARKYN, Ernest A.:

1915 PREHISTORIC ART. London.

PATRÓN, Pablo:

1909 INFLUENCIAS DEL DOMINIO PERUANO EN CHILE. Boletín de la Sociedad Geográfica de Lima, pp. 174-239; 295-353.

PEABODY, Francis Greenwood:

1918 EDUCATION FOR LIFE. New York.

PEAKE, Harold:

1914 A BRIEF DESCRIPTION OF THE HISTORY OF THE CIVILIZATION OF THE OLD WORLD. Newbury (England). 
PEET, E. T.:

1914 ABYDOS. London.

PENAFIEL, Antonio:

1890 MONUMENTOS DEL ARTE MEXICANO ANTIGUO. Berlin. 3 vols.

PENAFIEL, Antonio:

1899 TEOTIHUACAN. Mexico.

PETRE, M. D.:

I9I8 DEMOCRACY AT THE CROSS ROADS. London.

PETRIE, W. M. Flinders:

I896 NAGADAH. London.

PETRIE, W. M. Flinders:

190I DIOSPOLIS PARVA. London.

PHILLIPPS, Lisle March:

1915 FORM AND COLOUR. New York.

PHILLIPPS, Lisle March:

1916 EUROPE UNBOUND. New York.

PIETTE, Edouard:

1907 L'ART PENDANT L'AGE DU RIENNE. Paris.

POLO, José Toribio:

1899 LA PIEDRA DE CHAVIN.

Boletín de la Sociedad Geográfica de Lima, IX, pp. 192-231.

POOLEY, A. M.:

1917 JAPAN AT THE CROSS-ROADS. New York.

POPENHOE, Paul: and JOHNSON, Roswell Hill:

I918 APPLIED EUGENICS. New York.

POSNANSKY, Arthur:

I9I0 TIHUANACU Y LAS RAZAS Y MONUMENTOS PREHISTÓRICOS.

International Congress of Americanists, XVIIth Session, pp. 267-268.

POSNANSKY, Arthur:

19I4 UNA METROPOLI PREHISTÓRICA EN LA AMERICA DEL SUD. Berlin.

POSNANSKY, Arthur:

1918 EL GRAN TEMPLO DEL SOL EN LOS ANDES.

Boletín de la Sociedad Geográfica de La Paz, XVI, pp. 36-46.

PRADO Y UGARTECHE, Javier:

I894 ESTADO SOCIAL DEL PERU DURANTE LA DOMINACIÓN ESPANOLLA. Lima.

PREUSS, K. Th.:

I9I4 REISEBRIEF AUS KOLOMBIEN.

Zeitschrift fuer Ethnologie, XLVI, pp. 106-113. 
PUMPELLY, Raphael Welles:

1908 ANCIENT ANAU.

Carnegie Institution of Washington, Publication No. 73, Washington, 2 vols.

PUTNAM, Edward K.:

1914 THE DAVENPORT COLLECTION OF NAZCA AND OTHER PERUVIAN POTTERY.

Proceedings of the Davenport Academy of Sciences, XIII, pp. 17-40. Davenport (Iowa, U. S. A.).

RAI, Lajpat:

1917 ENGLAND'S DEBT TO INDIA. New York.

RAMIS Y RAMIS, Juan:

1818 ANTIGUUEDADES CELTICAS DE LA ISLA DE MENORCA. Mahon (Balearic Islands).

RAMIS Y RAMIS, Juan:

I819 HISTORIA DE MENORCA. Mahon(?).

RANDALL-MACIVER, David:

1902 EL AMRAH AND ABYDOS. London.

RANDALL-MACIVER, David:

1906 MEDIAEVAL RHODESIA. London.

RAWLINSON, George:

1903 THE ORIGIN OF NATIONS. New York.

REINSCH, Paul:

1902 COLONIAL GOVERNMENT. New York.

REISS, Wilhelm: and STUEBEL, Alphons:

1880-87 THE NECROPOLIS OF ANCON. Berlin. 4 vols.

REMUSAT, J. P. Abel:

1820 HISTOIRE DE LA VILLE DE KHOTAN. Paris.

RESTREPO, Vicente:

1895 LOS CHIBCHAS. Bogotá.

RESTREPO TIRADO, Ernesto:

1912 LOS QUIMBAYAS. Bogotá.

RESULTS OF THREE YEARS' ADMINISTRATION OF CHOSEN SINCE ANNEXATION.

Published by the Government-General of Chosen, Seoul, 1914.

REUTER, Edward Byron:

I918 THE MULATTO IN THE UNITED STATES. Boston. REVILLE, Albert:

1884 THE NATIVE RELIGIONS OF MEXICO AND PERU. New York.

RIVA-AGÜERO, José de la:

I910 LA HISTORIA EN EL PERÚ. Lima. 
RIVA-AGUEERO, José de la:

I9I6 ELOGIO DEL INCA GARCILASO.

Revista Universitaria de la Universidad Mayor de San Marcos, XI, pp. 335-412. Lima.

ROBERTS, Charles:

I9I8 INDIAN REFORMS.

The Contemporary Review, No. 633, pp. 237-245.

ROBERTSON, James Alexander:

I915 THE EVOLUTION OF REPRESENTATION IN THE PHILIPPINE ISLANDS.

Journal of Race Development, VI, pp. 155-166.

ROBERTSON, James Alexander:

1917 THE SOCIAL STRUCTURE OF, AND IDEAS OF LAW AMONG, EARLY PHILIPPINE PEOPLES.

In THE PACIFIC OCEAN IN HISTORY, pp. 160-19r. New York.

ROGERS, Robert William:

1915 A HISTORY OF BABYLONIA AND ASSYRIA. New York. 2 vols.

RUGE, Sophus:

I894 PRINZ HEINRICH DER SEEFAHRER. Brunswick (Germany).

RUSSIER, H.: and BRENIER, H.:

1910 L'INDO-CHINE FRANÇAISE. Paris.

SAAVEDRA, Juan Bautista:

1909 EL AYLLU. La Paz.

SAHAGÚN, Bernardino de:

I829 HISTORIA DE LA CONQUISTA DE MEXICO. Mexico. SANCHO, Pedro:

1917 AN ACCOUNT OF THE CONQUEST OF PERU. Edited by Philip Ainsworth MEANS. Cortes Society, New York. SANTAREM, Vizconde de:

Edited: AZURARA, I84r.

SARKAR, Benoy Kumar:

I9I8 THE INFLUENCE OF INDIA ON WESTERN CIVILIZATION IN MODERN TIMES.

Journal of Race Development, IX, pp. 91-104.

SARMIENTO DE GAMBOA, Pedro:

1907 HISTORY OF THE INCAS. Edited by Sir Clements R. MARKHAM, Hakluyt Society, London. 
SAVILLE Marshall H.:

1892 EXPLORATIONS ON THE MAIN STRUCTURE AT COPAN, HONDURAS.

Proceedings of the American Association for the AdvanceSAVILLE, Marshall H.: ment of Science, XLI, pp. 271-275.

1907-10 ANTIQUITIES OF MANABI, ECUADOR. New York. 2 vols.

SAVILLE, Marshall H.:

Edited: ANONYMOUS CONQUEROR, 1917.

SCHURMAN, Jacob Gould:

Edited: LEWIS, 1901.

SCHWEGLER, A.:

1853-58 RÖMISCHE GESCHICHTE. Tübingen (Germany).

SEIGNOBOS, Charles:

1902 HISTORY OF THE ROMAN PEOPLE. New York.

SERGI, Guglielmo:

I90I THE MEDITERRANEAN RACE. London.

SEYMOUR, Frederick:

1910 UP HILL AND DOWN DALE IN ANCIENT ETRURIA. London.

SILLARS, R. W.:

I916 THE NEXT STEP IN DEMOCRACY. New York.

SLOANE, William M.:

1895 HISTORY AND DEMOCRACY.

SMITH, Grafton Elliot:

American Historical Review, I, pp. I-23.

1912 MEGALITHIC MONUMENTS AND THEIR BUILDERS.

Man, XII, p. 173. London.

SMITH, Grafton Elliot:

1913 THE ORIGIN OF THE DOLMEN.

Man, XIII, p. 193. London.

SMITH, Grafton Elliot:

1915 ON THE SIGNIFICANCE OF THE DISTRIBUTION OF THE PRACTICE OF MUMMIFICATION. Manchester (England).

SMITH, Grafton Elliot:

I916 THE ORIGIN OF THE PRE-COLUMBIAN CIVILIZATION OF AMERICA.

Science, N. S., XLIV, pp. 140-145.

SMITH, S. Percy:

1904 HAWAIKI. Christchurch, New Zealand. 
SMITH, Vincent A.:

I90I ASOKA. Oxford.

SMITH, Vincent A.:

I908 THE EARLY HISTORY OF INDIA. Oxford.

SMITH, Vincent A.:

I9II A HISTORY OF FINE ART IN INDIA. Oxford.

SMITH, Vincent A.:

I916 THE OXFORD STUDENT'S HISTORY OF INDIA. Oxford:

SNOW, Alpheus H.:

1902 THE ADMINISTRATION OF DEPENDENCIES. New York.

SPILLER, G.: (Editor)

I9II PAPERS ON INTER-RACIAL PROBLEMS COMMUNICATED TO THE FIRST UNIVERSAL RACES CONGRESS. London.

SPINDEN, Herbert J.:

1913 A STUDY OF MAYA ART.

Peabody Museum (Harvard University), Memoirs, VI. Cambridge (Mass.)

SPINDEN, Herbert J.:

1915 NOTES ON THE ARCHEOLOGY OF SALVADOR.

American Anthropologist, N. S., XVII, pp. 434-450.

SPINDEN, Herbert J.:

I917 THE ORIGIN AND DISTRIBUTION OF AGRICULTURE IN AMERICA.

International Congress of Americanists, XIXth Session, pp. 269-277.

SPINDEN, Herbert J.:

1917b ANCIENT CIVILIZATIONS OF MEXICO AND CENTRAL AMERICA. New York.

SPRAGUE, Franklin M.:

I895 THE LAWS OF SOCIAL EVOLUTION. Boston.

SQUIER, E. George:

I877 PERU . . . New York.

STANLEY OF ALDERLEY, Lord:

Editor of ALVAREZ, I88I.

STARR, Frederick:

I9I8 KOREAN BUDDHISM. Boston.

STATESMAN'S YEARBOOK, Edited by John Scott KELTIE. London, 1918.

STEIN, Sir M. Aurel:

1903 THE SAND-BURIED R.UINS OF KHOTAN. London. 


\section{BIBLIOGRAPHY}

STEIN, Sir M. Aurel:

1903b EXPLORATIONS IN CHINESE TURKESTAN. Smithsonian Institution, Report for 1903, pp. 747-774. Washington.

STEIN, Sir M. Aurel:

1907 ANCIENT KHOTAN. Oxford. 2 vols.

STEIN, Sir M. Aurel:

1912 RUINS OF DESERT CATHAY. London. 2 vols.

STOEPEL, K. Th.:

I912 ARCHAEOLOGICAL DISCOVERIES IN ECUADOR AND SOUTHERN COLOMBIA ... AND THE ANCIENT STONE MONUMENTS OF SAN AGUSTIN. International Congress of Americanists, XVIIIth Session, pp. $251-258$.

STUEBEL, Alphons: and UHLE, Max:

1889-90 KULTUR UND INDUSTRIE DER SUUD-AMERIKANISCHEN VOELKER. Berlin. 3 vols.

SUNDERLAND, Jabez T.:

1917 RISING JAPAN. New York.

SYDENHAM OF COMBE, Lord:

1915 INDIA AND THE WAR. London.

SYKES, Sir Percy Molesworth:

1902 TEN THOUSAND MILES IN PERSIA. New York.

SYKES, Sir Percy Molesworth:

I915 A HISTORY OF PERSIA. London. 2 vols.

TELLO, Julio C.:

1917 LOS ANTIGUOS CEMENTERIOS DEL VALLE DE NASCA.

Proceedings of the Second Pan-American Scientific Congress,

I, pp. 283-29I. Washington.

TELLO, Julio C.:

I9I8 EL USO DE LAS CABEZAS HUMANAS ARTIFICIAL MENTE MOMIFICADAS. Lima.

TERNAUX-COMPANS, H.:

Edited: CAVELLO BALBOA, 1840.

ALVA IXTLILXOCHITL, 1840.

TEZOZOMOC, Fernando de Alvarado:

(See ALVARADO TEZOZOMOC, Fernando de:)

THOMPSON, A. S.:

1859 STORY OF NEW ZEALAND. Christchurch (New Zealand). 
THOMPSON, Edward H.:

1904 ARCHAEOLOGICAL RESEARCHES IN YUCATAN.

Peabody Museum (Harvard University), Memoirs, III, No. 1. Cambridge (Mass.)

TOZZER, Alfred Marston:

I9I I A PRELIMINARY STUDY OF THE PREHISTORIC RUINS OF TIKAL.

Peabody Museum (Harvard University), Memoirs, V, No. 2. Cambridge, (Mass.)

TOZZER, Alfred Marston:

I916 THE DOMAIN OF THE AZTECS.

Holmes Anniversary Volume, pp. 464-468. Washington.

TOZZER, Alfred Marston:

1917 THE CHILAM BALAM BOOKS. . . .

International Congress of Americanists, XIXth Session, pp. $178-186$.

TUFTS, James H.:

1917 OUR DEMOCRACY. New York.

UHLE, Max:

1903 PACHACAMAC.

University Museum. Philadelphia.

UHLE, Max:

1910 TIPOS DE CIVILIZACIÓN EN EL PERÚ.

Boletín de la Sociedad Geográfica de Lima, XXV, pp. 289-

UHLE, Max: 294.

I9Iob LOS ORÍGENES DE LOS INCAS.

International Congress of Americanists, XVIII, pp. 302-353. UHLE, Max:

1912 DIE MUSCHELHUEGEL VON ANCON.

International Congress of Americanists, XVIII, pp. 22-45.

ULLOA SOTOMAYOR, Alberto:

1917-18 ORGANIZACIÓN SOCIAL Y LEGAL DEL TRABAJO EN EL PERÚ.

Revista Universitaria. Lima.

URIBE ANGEL, Manuel:

188.5 ESTADO DE ANTIOQUIA. Paris.

URICOECHEA, Ezequiel:

1854 MEMORIAL SOBRE LAS ANTIGÜEDADES NEOGRANADENSES. Berlin.

URICOECHEA, Ezequiel:

1871 GRAMÁTICA DE LA LENGUA CHIBCHA. Paris. 
URTEAGA, Horacio:

I9I4 BOCETOS HISTÓRICOS. Lima.

URTEAGA, Horacio:

Edited: GARCILASO DE LA VEGA, 1918.

VERGERS, Noel des:

1862-64 L'ÉTRURIE ET LES ETRUSQUES. Paris. 3 vols.

VERNEAU, R.: and RIVET, P.:

1912 ETHNOGRAPHIE ANCIENNE DE L'EQUATEUR. Paris.

VOLKENS, G.:

I9OI UEBER DIE KAROLINEN INSEL YAP.

Verhandlungen d. Gesellschaft fuer Erdkunde, XXVIII.

WALCOTT, Arthur S.:

1914 JAVA AND HER NEIGHBOURS. New York.

WALDSTEIN, Sir Charles:

1917 ARISTODEMOCRACY. New York.

WALLACE, Alfred Russel:

1870 CONTRIBUTIONS TO THE THEORY OF NATURAL SELECTION. London.

WALLACE, Alfred Russel:

1889 DARWINISM. London.

WARD, Robert DeCourcy:

I9I8 CLIMATE. New York.

WEALE, B. L. Putnam:

I9Io THE CONFLICT OF COLOUR. New York.

WEIGALL, Arthur E. P. Brome:

I915 EGYPT FROM 1798 TO 1914. Edinburgh.

WEYL, Walter E.:

I9I8 THE END OF THE WAR. New York.

WHITE, John:

1886-89 THE HISTORY OF THE MAORI.

Wellington, New Zealand. 4 vols.

WHITEWAY, R. S.:

Editor of CASTANHOSO, 1902.

WIESSE, Carlos:

I9I3 LAS CIVILIZACIONES PRIMITIVAS DEL PERU์. Lima.

WILKINSON, Sir J. Garnder:

1878 THE ANCIENT EGYPTIANS. London. 3 vols. 
WINCKLER, Hugo:

1907 THE HISTORY OF BABYLONIA AND ASSYRIA.

Translated and edited by James Alexander CRAIG. New York.

WISSLER, Clark:

1917 THE AMERICAN INDIAN. New York.

WOODRUFF, Charles Edward.

1909 EXPANSION OF RACES. New York.

WORCESTER, Dean C.:

1914 THE PHILIPPINES PAST AND PRESENT. New York. 2 vols.

WYLDE, Augustus B.:

I90I MODERN ABYSSINIA. London.

YULE, Sir Henry:

1903 THE BOOK OF SER MARCO POLO. Revised edition by Henri CORDIER. London. 2 vols. 




\section{PLEASE DO NOT REMOVE CARDS OR SLIPS FROM THIS POCKET}

\section{UNIVERSITY OF TORONTO LIBRARY}

HT Means, Philip Ainsworth

1523 Racial factors in democracy

M4 


$$
\text { 范 }
$$

